Portland State University

PDXScholar

6-2009

\title{
Working for the "Working River": Willamette River Water Pollution, 1926 to 1962
}

James Vincent Hillegas

Portland State University

Follow this and additional works at: https://pdxscholar.library.pdx.edu/open_access_etds

Part of the Public History Commons, United States History Commons, and the Urban Studies and Planning Commons

Let us know how access to this document benefits you.

\section{Recommended Citation}

Hillegas, James Vincent, "Working for the "Working River": Willamette River Water Pollution, 1926 to 1962" (2009). Dissertations and Theses. Paper 3570.

https://doi.org/10.15760/etd.5454

This Thesis is brought to you for free and open access. It has been accepted for inclusion in Dissertations and Theses by an authorized administrator of PDXScholar. Please contact us if we can make this document more accessible: pdxscholar@pdx.edu. 


\section{THESIS APPROVAL}

The abstract and thesis of James Vincent Hillegas for the Master of Arts in History were presented June 9, 2009, and accepted by the thesis committee and the department.

COMMITTEE APPROVALS:

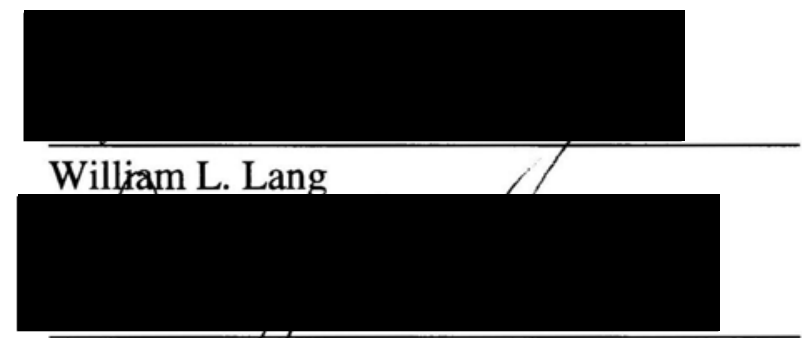

David A. Johrnson

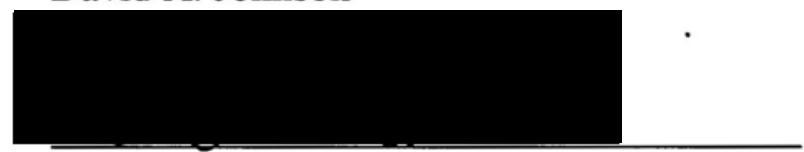

Carl Abbott

DEPARTMENT APPROVAL:

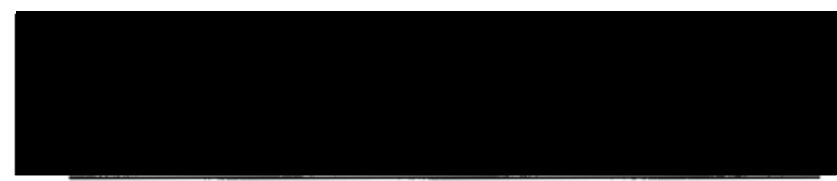

Thomas Luckett, Chair

Department of History 


\begin{abstract}
An abstract of the thesis of James Vincent Hillegas for the Master of Arts in History presented June 9, 2009.
\end{abstract}

Title: Working for the "Working River": Willamette River Water Pollution, 1926 to 1962

Efforts to abate Willamette River pollution between 1926 and 1962 centered on a struggle between abatement advocates and the two primary polluters in the watershed, the City of Portland and the pulp and paper industry. Throughout the twentieth century, the Willamette was by far the most heavily populated and industrialized watershed in Oregon. Like many other of the world's rivers, the Willamette was an integral part of municipal and industrial waste removal systems. As such, the main stem of the river carried the combined wastes from sewage outfalls serving hundreds of thousands of people and millions of gallons daily of pulp and paper making effluents. Exacerbating the impacts of these pollutants on the Willamette were unavoidable geologic and hydrologic constraints impacting the river's flow and, therefore, the river's ability to dilute wastes.

As the pollution load in the Willamette River increased throughout the twentieth century, accustomed activities such as recreation, sports fishing, and commercial fishing, were constrained. The polluted water also threatened potential uses of the river, such as tourism and expanded recreation after World War II. To 
address these concerns, beginning in 1926 clean streams advocates created ad hoc groups of public health experts, sanitary engineers, conservationists, sportsmen, and others to pressure Portland officials and industry representatives to cease polluting the river. In November 1938, continued activism and lobbying from these groups led to the passage of a citizen's initiative creating the Oregon State Sanitary Authority (OSSA). From 1939 to 1962 , the OSSA took the lead in the water pollution abatement issue and realized some limited successes including pushing Portland and other cities to build sewage treatment plants and regulating pulp and paper mill discharges. However, in spite of these accomplishments, the issue of water quality grew more complex and difficult through the 1950s, as reflected in Tom McCall's November 1962 television documentary Pollution in Paradise. 


\title{
WORKING FOR THE "WORKING RIVER": \\ WILLAMETTE RIVER WATER POLLUTION, 1926 TO 1962
}

by

\section{JAMES VINCENT HIILLEGAS}

A thesis submitted in partial fulfillment of the requirements for the degree of

\author{
MASTER OF ARTS \\ in \\ HISTORY
}

Portland State University

2009 


\section{ACKNOWLEDGMENTS}

This thesis would not have been possible without the assistance of many people. The support, mentorship, and feedback from my thesis committee have all been essential. Bill Lang and Bill Robbins provided thorough readings of draft versions that were invaluable in helping me refine my argument and expand my understanding. I greatly appreciate the assistance of archivists, particularly the staff and volunteers at the Oregon Historical Society Research Library and Brian Johnson at Portland's Stanley Parr Archives and Records Center. The staff at the Oregon State Department of Environmental Quality office in Portland provided access to the minutes of the Oregon State Sanitary Authority, a source that is central to my work.

It is unfortunate that David Charlton passed away long before I began my research, for I would have liked to thank him personally for having the foresight to save so many of the records essential in any project on twentieth century water pollution abatement in Oregon.

I thank my mother for instilling in me an insatiable quest for knowledge. Thanks also to all of my friends and family who have had to put up with my excessive absorption in this work for so much of the past two-plus years; Seth Moody and Sherry Palmiter, in particular, showed exceptional patience while listening for what must have seemed interminable periods as I attempted to make sense of my research. Finally, I would like to thank Jennifer Mangnall, who has tolerated my hectic schedule with grace and who has supported me with healthy food, good times, and grounding energy. 
Acknowledgments $\ldots \ldots \ldots \ldots \ldots \ldots \ldots \ldots \ldots \ldots \ldots \ldots \ldots \ldots \ldots \ldots \ldots, \quad i$

List of Abbreviations $\ldots \ldots \ldots \ldots \ldots \ldots \ldots \ldots \ldots \ldots \ldots \ldots \ldots \ldots$, iii

Introduction. David B. Charlton's Questions $\ldots \ldots \ldots \ldots \ldots \ldots \ldots \ldots, 1$

Chapter 1. Facing the Questions: Cities, Industries, and Willamette River Water Quality to $1926 \ldots \ldots \ldots \ldots \ldots \ldots . \ldots$

Chapter 2. "Antipathy for Evil": Advocates Push to Strengthen

State Water Pollution Laws, 1926 to $1938 \ldots \ldots \ldots \ldots \ldots \ldots . \quad 38$

Chapter 3. "Being Extremely Practical": The Sanitary Authority

Confronts Portland City Officials, 1939 to $1948 \ldots \ldots \ldots \ldots \ldots .69$

Chapter 4. "Cleaner But Not Clean":

The Limited Successes of Abatement Advocates, 1948-1962 _... 91

Conclusion. The Willamette River after Pollution in Paradise ....... 133

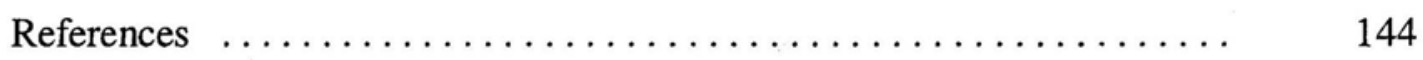

Appendix A. Pollution Management, 1900s-1970s ............. 155

Appendix B. The Oregon Division, Izaak Walton

League of America ..........................

Appendix C. An Analysis of Pollution in Paradise ............ 174 


\section{LIST OF ABBREVIATIONS}

ACSP: Advisory Committee on Stream Purification

A-SPL: Anti-Stream Pollution League

IJC: International Joint Commission

IWLA: Izaak Walton League of America

LOC: League of Oregon Cities

NSCI: National Council for Stream Improvement of the Pulp, Paper, and Paperboard Industries, Inc.

NRC: National Resources Committee

OB\&I: Oregon Business \& Investors, Inc.

OSC: Oregon State College

OSPB: Oregon State Planning Board

OSPL: Oregon Stream Purification League

OSSA: Oregon State Sanitary Authority

PNWRPC: Pacific Northwest Regional Planning Commission

PRDC: Postwar Readjustment and Development Commission

USACE: U.S. Army Corps of Engineers

USPHS: U.S. Public Health Service 


\section{INTRODUCTION}

\section{David B. Charlton's Pressing Questions}

David B. Charlton began his career as a chemist in 1926 when the Portland Bureau of Health hired him to be a laboratory technician. Two years later, he served briefly as an instructor of bacteriology at Oregon Agricultural College (later Oregon State University) and then left the state to complete advanced degrees. Upon earning his doctorate in bacteriology in 1933, he returned to Portland, opened his own business (Charlton Laboratories), and joined the local chapter of the Izaak Walton League of " America (IWLA). It was in his capacity as an independent contractor that Charlton began work to abate Willamette River pollution. He continued his involvement in water quality issues through the early 1980s, both in his professional role and as an active IWLA member at the local, state, and national levels. ${ }^{1}$

Reflecting on his first-hand experience of the long struggle to clean the Willamette River, Charlton wrote in 1975:

There is another aspect of the story that should be of interest to environmentalists and historians. I refer to the awakening of the people to the fact that there was a stream pollution problem. But who were really concerned and took action leading to the first investigations of the problem and then to take corrective action? Was it the State Board of Health; the Game and Fish Commissions? Did organized sportsmen, such as the Multnomah Anglers and Hunters Club, which was founded before the turn of the century, play an important role in initiating action? Just how active were the Waltonians ${ }^{2}$ of the Portland Chapter and in other chapters such as Silverton, which were chartered in the 1922 to 1930 period?

Charlton was responding to "the much reported and commented Clean-up of the Willamette River" of the late 1960s and 1970s that had appeared in a number of 
national publications. ${ }^{3}$ The improved condition of the Willamette in the 1970 s, the "Bottle Bill" of 1971, and Oregon's adoption of pioneering urban growth regulations in 1973 were all evidence of the state's leadership in environmental issues.

Environmentalists, politicians, academics, and others touted Oregon's example as an indication of the potential for future progress across the nation.

There is an implicit critique in Charlton's words, however. He characterized the clean-up narrative as "what might be called the McCall version that appeared in the National Geographic." Here he was referencing Ethel Starbird's article in the June 1972 National Geographic and other simplified narratives that focused almost exclusively on the efforts of Oregon Governor Tom McCall. ${ }^{4}$ Charlton raised an intriguing question in 1975 that challenged popular conceptions, and his question has not yet been answered sufficiently: Who were the people involved in awakening a critical mass of citizens to the need for water pollution abatement? $?^{5}$ As would be expected in an examination of efforts across five decades involving private citizens, municipal officials, and staff from a host of state and federal agencies, the answer to Charlton's question is multifaceted.

A recurring conflict involving the three primary groups participating in the Willamette River water pollution debate characterizes the period 1926 to 1962 . On one side were the pollution abatement advocates, a grouping of diverse individuals, established conservation and civic organizations, and ad hoc associations made up of state and federal officials, public health experts, sanitary engineers, and conservationists. In their efforts to abate the primary sources of pollution within the 
Willamette watershed—municipal sewage and pulp and paper mill effluents-these advocates clashed often with members of two other groups: Portland city officials and industry representatives.

Reflecting their diversity, pollution abatement advocates approached the issue from a variety of moral, philosophical, and practical positions. However, two essential elements propelled and sustained their advocacy. The first was the undeniable degradation of the Willamette River, Columbia Slough, and lower Columbia River that led to tangible, negative impacts on lives and livelihoods. The second was empirical evidence provided by increasingly more numerous and refined water quality surveys conducted by civic organizations, the City of Portland, and state and federal agencies. Equipped with qualitative and quantitative data, abatement advocates lobbied Portland city officials to invest both taxpayer funds and political capital to build sewage treatment facilities. They also applied their data to convince, and later compel, pulp and paper industry officials to commit time and money to develop technologies to use or treat mill effluents.

Countering the arguments of abatement advocates, Portland city leaders claimed that sewage infrastructure costs were prohibitive. City commissioners, mayors, and others often lamented the degraded state of the Willamette River but argued both during and after the Great Depression that sewage infrastructure costs would place an undue burden on Portland taxpayers. Pulp and paper industry executives defended their inaction along similar lines, stating that business operations would suffer if they were forced to internalize the costs of effluent treatment and reuse 
technologies. These executives also argued through the late 1940 s that they could not be expected to re-direct their wastes if the largest city in the state, Portland, was not treating its own municipal wastes. Finally, pulp and paper industry representatives also questioned some scientific findings and created their own research organization to develop data to enable them to continue to use the Willamette and Columbia rivers as sinks for their effluents.

The dynamic that defined the period 1926 to 1962 demonstrates the ways in which evidence of environmental degradation became the center of a conflict involving science, technology, politics, economics, and morality. Throughout the nation, evidence of water pollution became more apparent with the development of enhanced scientific tools to measure pollution and its effects. Many abatement advocates perceived empirical evidence of degraded streams and continued inaction by polluters as a moral or ethical shortcoming. However, complex economic and political considerations countered the possibility of immediate and direct application of pollution abatement technologies and practices. Using the example of Willamette River pollution to illustrate the recurrent conflicts at the municipal, state, and regional levels contributes to a broader understanding of how water quality became a national concern by the 1960 s. $^{6}$

The tangible impacts of environmental degradation were essential in motivating people to seek changes in policies, technologies, and practices. Polluted water harmed commercial fishing operations, threatened clean water sources for factories, and jeopardized tourist- and recreation-centered business activities. A 
substantial number of Oregonians also perceived excessively fouled water as blighting Portland's waterfront and as an "evil" within and beyond the city perpetuated against nature and future generations of Oregonians. Further, polluted water negated enjoyment by working-class residents seeking places to cool off in the summer as much as it curtailed the prospects for well-to-do angling club members to enjoy time at the local fly fishing spot. As Matthew Klingle illustrates in his environmental history of Seattle, useful insights can be gained from understanding the environment itself as a "physical agent" because the land, waterways, plants, and animals are "integral part[s] of the messy planet on which human action unfolds." This analytical lens is also useful in examining the history of Willamette River pollution abatement. As complex ecosystems are impacted by dams, effluent discharges, urban growth, and large-scale agriculture and logging, nature itself plays an active role in history by curtailing accustomed activities and constraining future options. ${ }^{7}$

Unavoidable environmental impacts brought together people with diverse interests and backgrounds to develop multifaceted legislative and regulatory solutions. Historians Richard W. Judd and Christopher S. Beach, in their comparison of water pollution abatement efforts in Oregon and Maine, write that "Americans needed a motive, in short, for improving their relation to nature." These historians find this motive arising from the transference of a romanticized "pastoral ideal" from the countryside to an urban setting after World War II. ${ }^{8}$ Research focused on the words and actions of clean streams advocates in Oregon finds that tangible, empirical impacts on public health, fish life, and accustomed activities also provided a strong 
motive. As historians Adam W. Rome, Gregory Summers, Donald Pisani, David Stradling, and others have shown, society's relationship to the environment tends not to change until people experience tangible negative impacts-until their own nests are fouled. ${ }^{9}$

Much has been written on efforts to clean the Willamette River from the 1920s through the early 1960s, but most of it is incomplete or inaccurate. Notable exceptions are the works of historians William G. Robbins, Brent Walth, Richard W. Judd, and Christopher S. Beach. Robbins showcases Willamette River cleanup efforts within a history of Oregon focused on the capitalist transformation of the state's environment. Walth outlines the problem of Willamette River pollution as a preface to journalist and future Oregon governor Tom McCall's involvement in the issue in the late 1950s. Judd and Beach discuss the topic in a comparative study of the evolution of a modern "environmental imagination" in Oregon and Maine. ${ }^{10}$

Most authors writing on this subject have extensively used the first comprehensive study of Willamette River pollution abatement efforts, George W. Gleeson's The Return of a River: The Willamette River, Oregon (1972). As a chemical engineering professor at Oregon State University from the 1930s to 1970, he authored some of the earliest sanitary surveys of the river and remained involved in the issue for the rest of his career. Gleeson wrote The Return of a River as part of an effort by state officials and university staff to chronicle, describe, and address environmental problems. The study summarizes water quality data gathered from 1926 through 1971 and identifies a few of the people and organizations involved in abatement efforts. 
Gleeson's account is valuable as a chronological narrative detailing water quality science and the effects and sources of pollution. It also makes data available in tables and charts, identifies specific Oregon statues pertaining to water quality, and provides a lengthy bibliography. What his work lacks, however, is the broader context and analysis that a historian can provide. ${ }^{11}$

Geographers, ecologists, engineers, journalists, and historians have authored studies of water pollution abatement in other states and at the federal level. These works approach the topic from politics, economics, science, society, and other perspectives. Some of these studies are particularly relevant to the example of Willamette River pollution.

Gregory Summers and Terence Kehoe have authored studies focused on a specific body of water during the same years that the pollution conflict raged along the Willamette River. Summers writes about pollution in the Fox River Valley of Wisconsin involving the pulp and paper industry and the state agency created in the late 1920s tasked with maintaining water quality. Central to Summers' interpretation is his discovery that conflicting groups held drastically different definitions of the value of the river to society, and these definitions were directly linked to the group's relationship to the river as "consumers" or "producers." Terence Kehoe's research offers insights into pollution abatement approaches in the Great Lakes during the immediate post-war years. He identifies a dynamic of "cooperative pragmatism" between state regulatory agencies and the regulated industries to achieve incremental water pollution abatement rather than establishing strict prohibitions. ${ }^{12}$ 
The works of Joel A. Tarr, Martin Melosi, and Arn Keeling complement one another by detailing interrelated aspects of municipal waste infrastructures, the metabolism of cities, disease etiology, and public health practices. Tarr has written numerous studies of sanitation infrastructures in industrialized Eastern cities that establish a periodization for the development of air, smoke, solid waste, and industrial waste disposal approaches. He also applies the concept of the "waste sink" as a central part of his work, by which he means the "tendency of both municipalities and industries constantly to seek new sites for waste disposal." Melosi builds upon Tarr's work in important ways by correlating technical and engineering approaches to urban waste disposal infrastructures with the dominant understanding of disease etiology by medical, public health, and sanitary engineering professionals. Keeling applies aspects of both Tarr's and Melosi's works to wastewater infrastructure in Vancouver, British Columbia, finding that city engineers through the 1960s saw the Fraser River as not just a receptacle for wastes but as an integral part of wastewater infrastructure. ${ }^{13}$

Christine M. Rosen, Jouni Paavola, Neil Shifrin, and Paul Charles Milazzo provide critical insights into the development of federal water pollution legislation and management. Rosen describes a gradual shift at the state level in resolving pollutionrelated conflicts. Into the twentieth century, arguments about the causes and effects of pollution were addressed in the courts, where judges were empowered only to redress grievances and did so by applying "balancing doctrine" based solely on economic considerations. By the early twentieth century, increasingly more Americans were finding the litigation process inadequate in an era of rapid industrialization and 
population growth because it was time-consuming, expensive, and did not provide a proactive abatement solution. As a result, states in the industrialized Northeast were the first to create agencies empowered to set water quality standards, monitor compliance provide for some enforcement. Works by Paavola and Shifrin continue the narrative of twentieth-century pollution management by establishing a framework of federal legislation and enforcement agencies tasked with addressing water pollution. Milazzo focuses specifically on legislative efforts after World War II to establish national water pollution standards and a federal agency capable of providing assistance to states and forcing compliance. ${ }^{14}$

Geographer Craig Colten contrasts the water pollution abatement struggle on Corney Creek in northern Louisiana from the 1930s to the 1960s to such efforts outside of the South. He asserts that Southern environmental history is unique in that "local government, civic organizations, and ad hoc advocacy groups" led the movement, "not national organizations like the Izaak Walton League." 15 In the case of the Willamette River, state government officials, ad hoc organizations, and state IWLA members were prominent pollution abatement advocates.

David Charlton was actively involved in the issue of Willamette River water pollution from the early 1930 s through the early 1980 s. Over these decades he compiled an extensive personal archive of correspondence, reports, studies, and other materials, which he donated to the Oregon Historical Society in 1983. His advocacy was informed and strengthened by his expertise and experience, and it was fueled by his passionate moral stance against water pollution. He believed that science and 
technology could provide practical, economical solutions to sewage and pulp mill effluents. As a leader in the local, state, and national IWLA, he also perceived water pollution in moral terms. At the same time, however, he sought to balance the competing uses of the "working" Willamette River. Because Charlton corresponded with city and state leaders, industry representatives, and experts throughout North America, his records provide a unique window into not only Oregonians' attempts to abate water pollution, but, more generally, into the important work of many local and state-level pollution abatement advocates for whom records may no longer exist.

Cleaning up the Willamette River required the efforts of many people besides David Charlton—as he himself observed—but his foresight in preserving evidence of these efforts is essential in telling a more complete story.

Water pollution sources \& measurement methods

Willamette River pollution abatement efforts from the 1920 s to the 1960 s centered on the two most significant sources of pollution: untreated domestic municipal wastes, sewage; and pulp and paper mill effluent, predominately sulfite liquors, processing chemicals, and suspended fibers flushed into the river. ${ }^{16}$ The most significant sources of these pollutants were sewage from the city of Portland and waste sulfite liquors from five pulp and paper mills in the Willamette Valley. The Crown Willamette (later Crown Zellerbach) Company owned mills at West Linn (built 1889) and Lebanon (built 1889); the Hawley Pulp \& Paper Company owned a mill at Oregon 
City (built 1909) that they sold to the Times Mirror company in 1948, which then changed the name to the Publishers' Pulp \& Paper Company; Oregon Pulp \& Paper Company (subsequently Boise-Cascade) operated a mill at Salem (built 1920); and the Spaulding Pulp \& Paper Company ran a mill in Newberg (built 1927). ${ }^{17}$

Critical to understanding the perspectives of people involved in Willamette Valley water pollution debates is an awareness of how these people defined a "polluted" stream. Depending upon one's training, vocation, and point of view, "pollution" could mean something empirical and tangible, or it could signify a moral or ethical dilemma. Many experts, for example, understood pollution as a matter of concentration or dilution and as a "reasonable use" of a stream, whereas other people perceived it as a sin against nature. ${ }^{18}$ For some people, it was both of these things.

Water quality analysis in Oregon reflected the most recent analytical models, measurement tools, and abatement technologies developed by scientists, public health experts, and sanitary engineers. From the first water quality studies of the Willamette River in the late 1920s, there were two primary indicators of point-source pollution that most concerned abatement advocates. ${ }^{19}$ The first was the dissolved oxygen (DO) content and the related measurement, biological (or biochemical) oxygen demand (BOD). DO is the amount of oxygen in a solution. Aquatic organisms require a minimal DO level to survive, generally 5 parts per million (ppm). BOD is the measurement of the oxygen requirements of a particular waste type during decomposition over a period of time, usually measured between five to twenty days. Standard BOD measurements are expressed in units such as " $\mathrm{BOD}_{5}$ " or " $\mathrm{BOD}_{20}$." 
Higher BOD measurements for a given effluent generally correlate with lower DO in the receiving body of water. The second important indicator of water quality was its bacteria count, particularly typhus and members of the coliform group, such as Escherichia coli (E. coli). Bacteria counts were measured in the number of organisms found per milliliter of water. ${ }^{20}$ Effluents with high BOD counts, such as untreated and partially-treated sewage and sulfite waste liquors, polluted water by reducing DO levels. In addition, untreated sewage also contained E. coli, typhus, and other bacteria. The fundamentals of paper making have been unchanged for hundreds of years. However, technological advances during the nineteenth and twentieth centuries facilitated increases in the size, number, and capacity of pulp and paper factories, leading to increased effluent amounts. To make paper, a solution of cellulose pulp produced from wood, other forms of fibrous vegetation, and/or recycled paper is passed through a screen, forming a mat of fibers. This mat is pressed, dried, and the resulting sheets cut to size. Chemical pulping methods began to replace mechanical methods in the late nineteenth century. These new ways to make pulp included the soda, sulfite, and sulfate (or "kraft") processes, all of which involved cooking wood chips in a solution of water and chemicals—or "liquor." After the cooking process, these liquors were then disposed of, untreated, into nearby bodies of water. In addition to residual pulping chemicals, expelled waste liquors also included varying amounts of wood fibers, lignins (sugars), bleaching compounds, dyes, and other chemicals. ${ }^{21}$ The predominant pulping process the five Willamette Valley mills used from the 1920s through the 1960 s was the sulfite process. ${ }^{22}$ 
Willamette River watershed hydrology, geography, and demographics

An essential aspect of water quality, expressed in DO and BOD measurements, is the proportion of water to wastes. The relative proportion of pollutants increases both with decreased overall water flow and increased discharges from cities and industries. Point-source pollution along the main stem of the Willamette River came from raw or partially-treated sewage from all communities along the river's banks and untreated effluents from a number of industries including pulp and paper, flax retting, fruit and vegetable processing, feed lots, and meat processing. As abatement advocates perceived and as the earliest water quality studies reflected, the most significant sources of Willamette River pollution from the 1920s through the early 1960s were municipal wastes from the city of Portland (and also from Eugene, Salem, and Newberg) and sulfite waste liquors from the five pulp and paper mills in the lower Willamette River basin. Although clean streams advocates prioritized efforts to abate these specific wastes, water pollution in and downriver from Portland's harbor was exacerbated by interrelated hydrologic, geographic, and demographic factors.

The 12,045-square-mile Willamette River watershed is part of the 259,000 square-mile Columbia River Basin. The Willamette is about 187 river miles in length from the junction of the Middle and Coast forks south of Eugene and drains a valley approximately seventy-five miles wide and 150 miles long. Over its length the Willamette drops 400 feet in elevation and has its highest velocity of flow in the upper 
half of its course. Major tributaries of the Willamette include the McKenzie, Santiam, Molalla, Clackamas, Long Tom, Marys, Luckiamute, Yamhill, and Tualatin rivers. After collecting its tributaries, the Willamette delivers the twelfth-largest flow of water in the United States to the Columbia approximately ninety-nine miles from the Columbia's confluence with the Pacific Ocean. ${ }^{23}$

The average daily flow of the Willamette River varies significantly, according to the season. This was particularly the case before the completion of the thirteen storage reservoirs of the Willamette Valley Project by the late 1960s. Information compiled from thirty-eight years of gauge records of daily water discharges at Eugene by the U.S. Army Corps of Engineers, published in October 1936, showed graphically that the low-water months were July through October. During these months, average daily water flow was approximately five thousand cubic feet per second. For comparison, the peak average flow during the December-through-March high-water months was just under thirty thousand cubic feet per second. ${ }^{24}$ In addition to seasonal fluctuations, the varying strengths of municipal and industrial effluents could change the character of the river overnight. Combined sewer overflows (CSOs), rapid releases of sulfite wastes liquors, population growth, and expanded industrial capacities increased the proportion of pollutants in receiving waters.

Also complicating Willamette River water pollution was the impact of tidal fluctuations and back-flow of the Columbia River. Scientists compiling hydrographic data in the 1930s found that tidal action caused river height to vary by as much as three feet in Portland Harbor, and Columbia River water could be found six miles up 
the Willamette. Being colder and denser, water from the Columbia entered the Willamette as a wedge at the bottom of the channel. ${ }^{25}$ For these reasons, it took up to 7.6 days for water to flow from Sellwood, at the south end of Portland, to the Multnomah Channel, a distance of approximately seventeen miles. ${ }^{26}$ These geologic and hydrologic factors specific to the Willamette River watershed tended to concentrate municipal and industrial wastes in the river downstream from Willamette Falls at Oregon City, particularly in Portland Harbor.

Geography and hydrology also influenced relative pollution levels in other ways. Upriver from Portland, the cities of Springfield, Eugene, Corvallis, Albany, Salem, and other communities directed raw sewage into the Willamette. Untreated wastes from the five valley pulp and paper mills also entered the Willamette upriver of Portland. Just as these upriver pollution sources contributed to degraded water quality within and downstream from Portland, pollution from Portland's sewers and Willamette Valley industries often extended to the Columbia Slough at the far northern edge of the city and to the lower Columbia River downstream from the confluence of the Willamette.

Demographics and industrial growth and concentration had complex impacts on water quality as well. The state's three most populous cities and most of the state's major industrial sites were within the Willamette Valley. Consistently throughout the twentieth century, most Oregon residents have lived in the Willamette Valley; in 2000, this equated to about two-thirds of the state's 3.7 million residents. ${ }^{27}$ In $1950,373,628$ Oregonians lived in the city of Portland itself. According to the 2000 census, 529,121 
people lived in the Portland metropolitan area, an increase of approximately 71 per cent over the intervening fifty years. ${ }^{28}$

The conflict over Willamette River pollution abatement took place within the context of evolving scientific methods, changing technologies, and region-specific geographic, hydrologic, and demographic factors. Abatement advocates, Portland officials, and pulp and paper industry representatives reacted to these complexities in quite different ways.

${ }^{1}$ David B. Charlton to Dr. Frank Terraglio, Portland State University, May 9, 1975, pp. 1-2, folder Water Pollution: Portland Area, box 18, David B. Charlton Papers (MSS 1900), Oregon Historical Society Research Library, Portland, Oreg. [hereafter Charlton Papers]; "City Expert to Leave," Morning Oregonian, Jan. 12, 1928, p. 5.

2 "Waltonians" is shorthand for members of the Izaak Walton League of America (IWLA).

${ }^{3}$ Charlton to Terraglio, p. 1 .

${ }^{4}$ Ethel Starbird, “A River Restored: Oregon's Willamette," National Geographic 141:6 (June 1972), 816-834. The essence of this popularized version of the narrative, with Tom McCall as the central figure, was repeated widely, including Lynton $\mathrm{K}$. Caldwell, Lynton R. Hayes, and Isabel M. MacWhirter, Citizens and the Environment: Case Studies in Popular Action (Bloomington, Ind., Indiana University Press, 1976), 90-93.

${ }^{5}$ Historian William G. Robbins has also noted Charlton's critique of these simplified characterizations. See William G. Robbins, Landscapes of Conflict: The Oregon Story, 1940-2000 (Seattle, Wash., University of Washington Press, 2004), 272.

${ }^{6}$ Other studies that explicitly focus on state and regional water pollution abatement efforts to contextualize the growing national concern during these decades include Terence Kehoe, Cleaning $U p$ the Great Lakes: From Cooperation to Confrontation (DeKalb, Ill., Northern Illinois University Press, 1997), Richard W. Judd and Christopher S. Beach, Natural States: The Environmental Imagination in Maine, Oregon, and the Nation (Washington, D.C., Resources for the Future, 2003), and Hugh S. Gorman, "Laying the Foundation for the Control of Industrial Pollution, 1930-1970: Two Canals, A Refinery, and Clarence W. Klassen," Joumal of Illinois History 8:3 (2005), 182-208.

${ }^{7}$ Matthew Klingle, Emerald City: An Environmental History of Seattle (New Haven, Conn., Yale University Press, 2007), 9.

${ }^{8}$ See Judd and Beach, Natural States, particularly 25-26.

${ }^{9}$ See Adam W. Rome, The Bulldozer in the Countryside: Suburban Sprawl and the Rise of American Environmentalism (Cambridge, U.K., Cambridge University Press, 2001); Gregory Summers, Consuming Nature: Environmentalism in the Fox River Valley, 1850-1950 (Lawrence, Kans., University Press of Kansas, 2006); Donald J. Pisani, "Fish Culture and the Dawn of Concern Over Water Pollution," Environmental Review 8:2 (1984), 117-131; and David Stradling, Smokestacks and Progressives: Environmentalists, Engineers and Air Quality in America, 1881-1951 (Baltimore, Md., Johns Hopkins University Press, 1999).

${ }^{10}$ See both Robbins, Landscapes of Conflict, chapter 8 (pp. 248-280), and William G. Robbins, Landscapes of Promise: The Oregon Story, 1800-1940 (Seattle, Wash., University of Washington 
Press, 1997), 305-310; Brent Walth, Fire at Eden's Gate: Tom McCall \& the Oregon Story (Portland, Oreg., Oregon Historical Society Press, 1994), chapter 7 (pp. 134-148); and Judd and Beach, Natural States. Most other treatments of this topic provide only the barest details. Of these studies, most are found in federal or state grey literature or in scientific reports; see, for example, William D. Honey, Jr., The Willamette River Greenway: Cultural and Environmental Interplay (Corvallis, Oreg., Oregon State University Water Research Institute, 1975). Elizabeth Orr and William Orr devote a chapter to pollution abatement in their book Oregon Water: An Environmental History (Portland, Oreg., Inkwater Press, 2005), but their treatment is cursory.

${ }^{11}$ George W. Gleeson, The Return of a River: The Willamette River, Oregon (Corvallis, Oreg., Oregon State University Water Research Institute, 1972).

${ }^{12}$ Summers, Consuming Nature; Keho, Cleaning Up the Great Lakes.

${ }^{13}$ Joel A. Tarr, The Search for the Ultimate Sink: Urban Pollution in Historical Perspective (Akron, Ohio, University of Akron Press, 1996), quote from p. xxxi; Martin V. Melosi, The Sanitary City: Urban Infrastructure in America from Colonial Times to the Present (Baltimore, Md., Johns Hopkins University Press, 2000); Arn Keeling, "Sink or Swim: Water Pollution and Environmental Politics in Vancouver, 1889-1975," BC Studies 142/143 (Summer/Autumn 2004), 69-101; and Keeling, "Urban Waste Sinks as a Natural Resource: The Case of the Fraser River," Urban History Review 34:1 (2005), 58-70.

${ }^{14}$ Christine M. Rosen, "Differing Perceptions of the Value of Pollution Abatement Across Time and Place: Balancing Doctrine in Pollution Nuisance Law, 1840-1906," Law and History Review 11:2 (Fall 1993), 303-381; Jouni Paavola, "Interstate Water Pollution Problems and Elusive Federal Water Pollution Policy in the United States, 1900-1948, Environment and History 12:4 (2006), 435-465; Neil S. Shifrin, "Pollution Management in the Twentieth Century," Journal of Environmental Engineering 131:5 (May 2005), 676-691; Paul Charles Milazzo, Unlikely Environmentalists: Congress and Clean Water, 1945-1972 (Lawrence, Kans., University Press of Kansas, 2006).

${ }^{15}$ Craig E. Colten, "Contesting Pollution in Dixie: The Case of Corney Creek," Journal of Southern History 72:3 (Aug. 2006), 609.

${ }^{16}$ The current spelling of the word "sulfite," instead of "sulphite," is used throughout this study except when from a direct quote. For more on the consistent focus on these primary sources of pollution through the 1950s, see Glenn D. Carter, "Pioneering Water Pollution Control in Oregon," Oregon Historical Quarterly 107:2 (Summer 2006), 254-272.

${ }^{17}$ These were the pulp and paper mills that pollution abatement advocates were primarily concerned with during the period under study. Three additional mills were built along the Willamette River after World War II, in Springfield (1949), Albany (1955), and Halsey (1969); see Gleeson, The Return of a River, 68.

${ }^{18}$ For the evolution of the term "pollution" during the Progressive Era, see Adam W. Rome, "Coming to Terms with Pollution: The Language of Environmental Reform, 1865-1915," Environmental History 1:3 (1996), 6-28. For the growing awareness of industrial pollution in the twentieth century, see Joel A. Tarr, "Industrial Waste Disposal in the United States as a Historical Problem," Ambix 49:1 (March 2002), 4-20. For changing definitions of pollution in waters surrounding Vancouver, B.C., in the twentieth century, see Keeling, "Sink or Swim."

${ }^{19}$ For concurrent developments in water quality science focused on siltation and eutrophication, see Frank N. Egerton, "Pollution and Aquatic Life in Lake Erie: Early Scientific Studies," Environmental Review 11:3 (Fall 1987), 189-206.

${ }^{20}$ Gleeson, The Return of a River, 11; C. V. Langton and H. S. Rogers, Preliminary Report on the Control of Stream Pollution in Oregon, Bulletin Series, No. 1 (Corvallis, Oreg., Oregon State Agricultural College Engineering Experiment Station, [March] 1929), 15. For the broader context of these measurement methods, see Keeling, "Urban Waste Sinks," 60-61. To a somewhat lesser degree, water quality specialists were also concerned with temperature, turbidity, suspended solids, nutrients, major ions, color, and odor. See Shifrin, "Pollution Management in the Twentieth Century," 679. 
${ }^{21}$ See Nancy Kane Ohanian, The American Pulp and Paper Industry, 1900-1940: Mill Survival, Firm Structure, and Industry Relocation (Westport, Conn., Greenwood Press, 1993), Appendix A (pp. 183192), for history and details of the pulp and paper making processes.

${ }^{22}$ By the 1970s, the less-polluting kraft process was in use at mills in Albany, Springfield, St. Helens, and other Oregon cities. See Carter, "Pioneering Water Pollution Control," 263.

${ }^{23}$ Gleeson, The Return of a River, 1-6.

${ }^{24}$ Oregon State Planning Board, "Willamette Valley Project Hydrographs, W.P.A. Project O.P. 2656905," fig. 20, Oct. 1936, available at http://www.sos.state.or.us/archives/state/planbd/pics/pdf/ will/h225.pdf, accessed Jan. 26, 2009.

${ }^{25}$ Gleeson, The Return of a River, 18.

26 "A Debate on Sewage Disposal," Sunday Oregonian, Oct. 11, 1936, magazine section, pp. 4-5.

${ }^{27}$ Gleeson, The Return of a River, 1-6; Douglas W. Larson, "Reservoir Limnology in the Pacific NW: Willamette River Basin, OR," Lakeline 21:4 (Winter 2001/2002), 11; Robbins, Landscapes of Conflict, 248.

${ }^{28}$ For 1950 census figures, see U.S. Bureau of the Census, Census of Population: 1950 OregonVolume II, Part 37, Characteristics of the Population, Number of Inhabitants, Oregon, pp. 12-13, available at http://www.census.gov/prod/www/abs/decennial/1950.htm, accessed Oct. 6, 2008. For 2000 census figures, see U.S. Bureau of the Census, State and County QuickFacts, http://quickfacts. census.gov/qfd/states/41/41051.html, accessed Jan. 26, 2009. In 2000, the Portland-VancouverBeaverton Metropolitan Statistical Area population numbered 1,936,027. 


\section{Chapter 1}

\section{FACING THE QUESTIONS:}

\section{CITIES, INDUSTRIES, AND WILLAMETTE RIVER WATER QUALITY TO 1926}

The Willamette River figured prominently in the lives of all who have inhabited the valley because it has served essential uses. Fish in the river were an important nutritional and economic resource. Many communities in the valley used river water for drinking and other domestic purposes. Portland's harbor expanded as a center of commercial shipping throughout the nineteenth century as the city's economic importance increased and the region's transportation network grew. ${ }^{1}$ In conjunction with these uses, by the turn of the twentieth century Portland residents were accustomed to using the river for swimming, boating, and other recreational purposes. The Willamette River also served valley residents and businesses as the primary "sink" for untreated sewage and an array of industrial wastes. With all of these concurrent and often conflicting uses, residents of Portland noticed the declining quality of Willamette River water as early as the 1880s. By the turn of the century, residents of upriver cities were making the same observations.

The Willamette River as a municipal water source

The degraded taste and odor of Willamette River water and threats to the public health spurred residents of valley cities to seek municipal water sources elsewhere. From the 1860 s into the early 1880 s, Portland's municipal water supply 
sources could not keep up with the demands of the growing population. In addition, pollution from upstream municipalities and effluent from pulp, paper, and other industries noticeably degraded the quality of water drawn from the Willamette River. These issues were exacerbated when tidal action affecting the Columbia River backed up the flow of the lower Willamette, causing wastes to drain slowly. ${ }^{2}$

Pressure from dissatisfied Portland citizens, politicians, and business leaders increased during the early 1880 s. The state legislature approved a charter amendment authorizing the city to sell bonds to fund the Portland Water Committee, established in November 1885 to secure an alternate municipal water source. The committee believed that the city did not need to build extensive treatment facilities, as had been done in other cities. They therefore looked well outside Portland city limits and sought to secure rights to the Bull Run watershed, an area of approximately 102 square miles of forest reserve straddling Multnomah and Clackamas counties east of Portland. Over a decade after the initial survey, Oregon Governor Sylvester Pennoyer inaugurated the first flow from the Bull Run reservoir into Portland on January 2, 1895. ${ }^{3}$

Other Willamette Valley cities ceased drawing municipal water from the river from the 1900s through the 1930s. After an outbreak of typhoid fever in 1906, Eugene residents lobbied successfully to have the city take over water treatment responsibilities from private ownership. In 1911, Eugene city engineers completed the Walterville Power Plant, primarily to pump McKenzie River water into the city. ${ }^{4}$ The city of Corvallis replaced their Willamette River water supply in 1906 with water drawn from the Mary's Peak watershed west of town. However, in 1949 city officials 
did authorize construction of a water treatment plant on the west bank of the Willamette River to augment supply during high demand periods. ${ }^{5}$ The city of Albany has drawn its municipal water from the eighteen-mile Santiam-Albany Canal at least as early as 1912 . The canal was built in 1872 to serve transportation and power generation purposes by diverting water from the Santiam River to the Willamette River. ${ }^{6}$ Salem city officials developed the North Santiam River watershed in 19361937 in reaction to public pressure since the 1910 s for a healthier water supply. ${ }^{7}$ Securing new municipal supplies solved one pressing issue, while decreasing the need to address Willamette River pollution directly, contributing in some ways to the continued use of the river as a waste sink.

The Willamette River as a "common sewer"

Potential health threats spurred the first concerns about Willamette River pollution, as they did throughout the United States, Canada, and Western Europe. The rapid expansion and concentration of urban populations made obvious the need for clean water supplies, effective ways to remove solid and liquid wastes, and improved sanitation practices to maintain community health. These needs brought increased attention and funding for scientific research, spurred the development of sanitary engineering technologies, and fostered increased professionalization. As a result, public health practices advanced significantly throughout the nineteenth and early twentieth century. ${ }^{8}$ 
The largest cities in the country and most states had established public health organizations by 1900 that thereafter grew increasingly more specialized. ${ }^{9}$ Somewhat behind states in the more densely populated Northeast and Great Lakes regions, the Oregon legislature created the State Board of Health in 1903. As was the case in many other states, Oregon's legislation addressed specific public health issues such as smallpox, typhoid, bubonic plague, and tuberculosis while also providing for health education. ${ }^{10}$

Representatives of the State Board of Health, newspaper editors, and others were aware of the steadily deteriorating quality of water in Portland and along the entire Willamette River. In February 1906, the Oregonian reacted to a typhoid epidenic linked to Eugene's Willamette River sewer outfalls by calling the river a "common sewer for the entire valley between the Cascade and Coast Ranges of mountains from Cottage Grove to the Columbia."11 Later in 1906 the Oregon State Board of Health observed typhoid in the Columbia River for the first time and identified the sources of this contagion as tributary streams in eastern Oregon as well as the Willamette. The Secretary of the Board of Health noted that the "Willamette River has not been free from typhoid germs for years." In response, an Oregonian reporter concluded that "it evidently behooves the many swimmers about Portland to cultivate the gentle art of keeping their mouths closed while in the water."12

Portland residents contributed significant amounts of typhoid-bearing raw sewage to Willamette River waters. Between 1905 and the mid-1920s, Portland nearly tripled in population. To serve the city's residents and booming businesses, city 
engineers built an extensive system of "combined" sewers-lines that collected both storm water runoff and human waste. ${ }^{13}$ All of these sewers sent untreated effluents directly into the Willamette River, Columbia Slough, and other local streams. Such disposal practices were the norm in cities and towns throughout the United States, Canada, and Europe; practical technologies to treat sewage so as to minimize bacteriological threats and reduce biological oxygen demand were not available until the 1910s. ${ }^{14}$ In May 1911 Oregon State Health Officer Dr. Calvin S. White echoed the sentiments of the Oregonian in 1906 by declaring the Willamette River an "open sewer." As part of the Health Board's continued efforts to eradicate typhoid, Dr. White called upon the legislature to outlaw the dumping of untreated sewage. ${ }^{15}$

Through the 1900s and 1910s, public health professionals in Oregon linked raw sewage to health threats, but state officials and valley residents were also experiencing the detrimental effects of industrial effluents on aquatic life. In late July 1911, Oregon's Master Fish Warden responded to a significant fish kill at Willamette Falls and authorized the arrest of Willamette Pulp \& Paper Company officials operating a mill at Oregon City. The Oregon State Legislature had empowered the state's Board of Fish and Game Commissioners to respond to instances of water pollution that harmed commercial and sport fish and bring suit against violators. ${ }^{16}$ In this instance, commissioners accused mill executives of discharging excessive pulp refuse and dyes and failing to release enough water from their dams to dilute these wastes. Graphic evidence of excessive pollution could be seen in the large number of dead fish and eels for several miles below Oregon City. ${ }^{17}$ 
State Game Warden William L. Finley also responded to this large fish kill. Finley was a founding member of the Oregon Audubon Society in 1902, having been involved in wildlife advocacy and photography for more than a decade. Finley would become a founding member of the Portland Chapter of the Izaak Walton League of America (IWLA) in late 1922 and would remain at the forefront of the Willamette River pollution abatement movement through the 1940s. ${ }^{18}$ In commenting upon the July 1911 incident at Willamette Falls, Finley noted that the waters below the Oregon City mills were so coated in a mixture of fuel oil and sawdust that the water was unfit both for fish and for swimming. ${ }^{19}$

Although Finley drew attention to the loss of recreational opportunities as well as the threat to aquatic life, the state legislature empowered the Oregon Fish and Game commissions to respond to fish deaths from water pollution for one specific reason: to maintain a quantity of fish sufficient for both sportsmen and commercial interests. ${ }^{20}$ Legislative mandate for both commissions did not include the public health aspects of polluted water; the legislature empowered the Oregon Board of Health to address this aspect. The state legislature did not authorize either the fish or game commissions or the health board to consider the loss of recreational opportunities, such as swimming. In these ways, the purview of Oregon fish and game commissioners and health board members were similar to such state agencies throughout the nation.

Even as state officials drew attention to degraded water quality that impacted public health and fish life in the 1910s and 1920s, Portland residents looked to the river for other purposes and newspaper editorials called for increased recreational use 
of the river. ${ }^{21}$ Leaders of the Apostolic Faith Mission of Portland conducted largescale baptisms in the Willamette River in July 1914, and a month later the first annual Willamette River marathon swim took place, from Oaks Park to the Morrison Street Bridge. ${ }^{22}$ Area residents continued to hold outdoor swimming and diving competitions at Oaks Park at least through the summer of $1921 .^{23}$ In the midst of this popularity, in 1915 Portland City Commissioner George Baker proposed a plan to increase amenities along the river by designating swimming areas and providing dressing rooms. Aware of the many sewer outfalls within city limits, Baker planned these swimming zones in and near Oaks Park, above most outfalls. ${ }^{24}$

In May 1922, the Portland Rowing Club filed an objection with Portland city commissioners to the proposed Lents trunk sewer outlet. Rowing Club representatives did not object to the outlet itself, entering just north of their property along the bank of the river. Their primary objection was that the outlet was not placed deep enough in the river channel to carry the effluent away and ensure protection against disease. ${ }^{25}$

The presence of raw sewage outfalls in such close proximity to recreational areas reflected the dominant belief in the assimilative and self-purifying capacities of flowing water. According to prevailing scientific and engineering orthodoxies, not only could bodies of water be used as waste sinks, locations for recreation, and, in many cases, even sources of potable water, but these seemingly mutually exclusive activities were also "reasonable uses" of streams. ${ }^{26}$

A "reasonably" used body of water in the 1910s and 1920s meant that it would serve the community-at-large in many ways. From the beginning of Euro American 
settlement in the valley, the Willamette had been a "working river," and "not primarily a decorative river," as the Portland Telegram stated in November 1922. The Willamette

has always dressed in working clothes. It is habitually unkempt. Its banks bristle with the rough rubbish of visionless, grubbing commerce. ... Like most rivers in American cities, [the Willamette] is a sewer, a back-door area, a clutter-yard, a dump, a workshop... ${ }^{27}$

As this editorial illustrates, residents of Portland perceived the Willamette in a variety of ways. ${ }^{28}$ Even when used reasonably, however, water quality in and near Portland continued to deteriorate, and excessive overall pollution levels were more apparent during the annual low-water periods of late summer through early fall. By the 1910s, pollution in the river began to threaten public health, harm prospects for sport and commercial fishing, and impact recreational activities.

Public health officials were aware of the direct link between this degradation and the city's sewer outfalls into the Willamette, Columbia Slough, and other local streams. Cooperative sewerage plans for the greater Portland metropolitan area had been proposed since at least 1916 as part of attempts to establish a comprehensive urban plan and planning commission. ${ }^{29}$ In 1924, Portland City Health Officer Dr. George Parrish recommended construction of a sewage treatment plant with effluents treated with chemicals in settling basins. Parrish made this appeal in part because he reasoned that keeping people from swimming in the river would be practically impossible, even if prohibitory ordinances were adopted. ${ }^{30}$ 
The Portland city council considered closing the Willamette River in Portland to swimming and recreation at least as early as the summer of 1924 . Portland's city health officer and chief sanitary inspector presented this option because of the threat of bacterial infection from raw sewage. In this particular instance, tidal action carried effluent from the Lents trunk sewer outfall upstream. ${ }^{31}$

Motivated by their growing awareness of increasingly degraded conditions, state legislators passed two bills in 1919 related to water pollution. One bill, titled "An Act to Protect from Pollution Water Furnished to the Inhabitants of Towns and Cities within the State of Oregon," defined prosecutable nuisances as activities that would degrade the quality of water supplies of towns and cities. It placed oversight, investigation, and enforcement authority at the municipal level, in the hands of designated health officials. On determining that the law had been violated, these city officials were authorized to bring a civil case against the offender at the county court. If the offender were found guilty, the court would then issue a warrant requiring the offender to cease immediately the nuisance condition. The second water pollution bill-“An Act to Create a 'State Board of Health"'-specified the role of the State Board of Health in regulating and monitoring municipal water sources, ensuring that towns, cities, and industries built sewer systems, conducting home and businesses inspections, and "generally providing for the protection of watersheds from contamination, and for the punishment of persons violating such law. ${ }^{32}$ The shortcomings of previous Oregon water quality statutes had helped motivate the legislature to pass the 1919 laws. In 1889, the legislature had enacted two 
statutes to promote drainage for both agriculture and sanitary reasons and to prohibit disposal of animal carcasses and other decaying matter into water sources used for domestic purposes. In 1911, the legislature had made it illegal for any "person or persons, company, association or corporation" to pollute the Deschutes and North Umpqua rivers with "sewage, refuse, waste or polluting matter, or any dead animal carcass" that would corrupt the water for domestic or municipal use. ${ }^{33}$ By the late 1910s, these laws had proven to be ineffective.

Oregon's 1919 water pollution laws reflected legislation in many other states and at the federal level. In states that pioneered water quality regulations such as Massachusetts, Pennsylvania, Maryland, Ohio, New Jersey, and New York, enforcement of water quality standards centered on protecting water supplies and economic investments, not on the general quality of streams. Federal laws and agency efforts were as narrowly focused. The 1899 Rivers and Harbors Act and the 1924 Oil Pollution Act pertained to pollution impacting commerce, and Congress established the U.S. Public Health Service (USPHS) in 1911 in part to study the pubic health impacts of water pollution. ${ }^{34}$

In late July 1925, the Oregon State Game Commission held the first conference to discuss municipal and industrial wastes impacting the Willamette River. The Oregon Legislature had reorganized the Oregon game and fish commissions in 1921 and included in this reorganization specific authority to address threats to sport and game fish. ${ }^{35}$ As one aspect of enhanced authority resulting from this reorganization, commissioners invited Dr. Henry B. Ward of the U.S. Bureau of Fisheries to their July 
1925 conference. Also at the conference were representatives from six Willamette Valley cities, the Portland city commissioner, health officers from the state and the city of Portland, and representatives from civic clubs and industries. Dr. Ward quantified the impact on the Willamette River fishery as being "worth in round figures about four to six millions of dollars a year., ${ }^{36}$

In an editorial the next day, the Oregonian excoriated the pollution of Oregon's streams, comparing them derogatorily to Chicago's recently completed Sanitary and Ship Canal. Chicago officials had the canal built to drain city wastes away from Lake Michigan, the city's water supply, into the Mississippi via the Illinois River. Such treatment of waterways was, in the opinion of the editor, "evil." Just as Oregon residents sought guidance on the water pollution issue from federal agencies, they were also well aware of environmental degradation experienced elsewhere. ${ }^{37}$

In August 1925, less than a month after the Oregon Game Commission's conference, Portland hosted another water pollution meeting. USPHS sanitary engineer H. B. Hommon told conferees that the federal government would conduct a comprehensive survey of the Willamette River within Portland city limits if the city council provided staffing and funding support. The goal of this survey was to quantify public health repercussions and offer abatement suggestions. Specific abatement steps, however, would be left to Portland city sanitary engineers. ${ }^{38}$ Officials from other Willamette Valley cities were also planning their own studies. The full survey was to take up to three years in order to gather a full range of seasonal water flow and pollution concentration measurements. ${ }^{39}$ Hommon commenced the survey in early 
February 1926 by producing a nine-page preliminary report outlining the basic equipment and staffing requirements needed to conduct a scientific sampling regimen of Willamette River water within and upriver of Portland. ${ }^{40}$

During the same period that federal experts were visiting Portland to discuss water quality issues, state and local leaders were debating proposals to upgrade the city's sewerage infrastructure. The state legislature had enhanced state oversight of water quality in 1925 by creating a sanitary engineering division within the Board of Health tasked with approving sewer system plans. ${ }^{41}$ Within this framework, Portland city engineer Olaf Laurgaard proposed a comprehensive redevelopment plan for Portland's harbor to rid the shoreline of derelict structures and protect the downtown core from floods by building a wall along the western bank of the river. ${ }^{42}$ Laurgaard's project included an intercepting sewer line and sewage pumping station to connect outfalls. These elements would address potential health threats and reverse depreciated values of downtown real estate caused by sewage backing up into the city's business district during high water periods. ${ }^{43}$ Responding to these plans, in late 1925 William Finley and others suggested that a sewage treatment plant and a more comprehensive, city-wide sewer system also be an integral part of Laurgaard's plan. ${ }^{44}$ However, USPHS sanitary engineer Hommon advised against including such extensive infrastructure within Laurgaard's initiative. In Hommon's opinion, it would not benefit Willamette Valley cities to make large-scale expenditures on sewage treatment systems until the results of water quality surveys were available. Based on the findings of the USPHS survey that would include calculations of the assimilative capacity of 
the Willamette and Columbia Rivers, Hommon asserted that it might not even be necessary for municipalities to treat their sewage at all. ${ }^{45}$

In his report of August 6, 1925, Laurgaard echoed Hommon's perspective in outlining the complexities and expense of sewerage infrastructure. He found that Portland's existing system of combined sewers would make treatment costly because of the large amount of mixed water and sewage in the system. Laurgaard also noted that the option of building an entirely new system of strictly sanitary sewers would be prohibitively expensive. Laurgaard did agree with federal officials and state "fish and game men," such as Finley, that treatment of Portland's sewage would be just one step in a broader program of cleaning up the river. Unlike Finley, however, Laurgaard concluded that taking this step was not worth the expense. ${ }^{46}$ In the end, the Laurgaard waterfront development plan, completed in 1929, did include interceptor lines for the combined sewer system along the river wall but no expanded system or treatment facilities. ${ }^{47}$

Laurgaard's economic justification for not building a more comprehensive system is a clear example of the kind of "path dependence" that historian Martin Melosi observes in urban histories throughout the nation. As Melosi describes, infrastructure investments at one stage of a city's growth tend to establish the parameters for subsequent infrastructure options. The more costly and labor-intensive an investment is the more financial and political capital it takes to implement changes that involve an abandonment or comprehensive revision of the existing system. ${ }^{48}$ 
Facing increased pollution and the inadequacies of Portland's sewage infrastructure, by early 1926 Oregon's fish and game commissioners and area sportsmen were allied in their opposition to communities directing raw sewage into the state's rivers and streams. Under the provisions of the state's 1919 water pollution laws, the Game Commission had the legal prerogative to disallow plans that included raw sewage outfalls. Commissioners took this stance in February 1926 when they opposed sewer plans Milwaukie city officials had developed. ${ }^{49}$ In early May of that year, State Game Warden Edgar F. Averill investigated "a black viscous coat" downstream from the city of Eugene that was claimed to have caused a large fish kill. Oregon's 1919 water pollution laws and the 1921 legislative reorganization of the fish and game commissions authorized Averill—who was also a member of the Oregon IWLA and would be an active clean-streams advocate for many years-to bring charges against Eugene city officials. Averill stated that water pollution was a menace to commercial and sports fisheries and public health. ${ }^{50}$

The examples of Milwaukie and Eugene notwithstanding, Oregon's water pollution laws had not been enforced extensively. The Oregonian reported that, by May 1926, these laws had only been applied in cases of "logging companies, steamships and others for emptying waste matter into rivers," but not in cases of largescale polluters such as municipalities and industries. ${ }^{51}$

Willamette Valley cities during the first three decades of the twentieth century were facing the same kinds of challenges experienced throughout the United States, Canada, and Europe. Urban populations were becoming increasingly concentrated and 
industrialized, while wastes were still being disposed of in the accustomed ways-by dumping into streams. A growing number of government officials and concerned citizens within and beyond Oregon were becoming increasingly aware of the negative impacts of this practice and began to search for new legal and administrative approaches.

Placing the example of Willamette River pollution abatement within a broader context, the first attempt at an international approach to water pollution in North America was centered on the Great Lakes region. The 1909 Boundary Waters Treaty between the United States and Canada established the International Joint Commission (IJC). The treaty empowered IJC members to develop cooperative management plans for water resources between the two nations. ${ }^{52}$ The next year, the Canadian Commission of Conservation held a conference in response to typhoid outbreaks in cities and towns along the shores of the Great Lakes. These communities drew their municipal water from the lakes, and the outbreaks were linked to contamination of these water supplies by untreated sewage from both Canadian and U.S. sources. Among the primary recommendations of conferees was that Canadian health officials work with their U.S. counterparts through the IJC to develop a comprehensive, basinwide approach to the public health threat. By the late 1910s, chlorine water treatment technologies eliminated the public health emergency, and efforts to develop a comprehensive basin-wide water pollution policy through the IJC ceased. ${ }^{53}$

Unlike the many communities drawing potable water from the Great Lakes, no city along the Willamette used the river as a source for municipal water supplies. 
Nevertheless, the drive to clean up the river began during the 1920s, at the same time that pollution management efforts of the IJC stalled. This shows that in the case of the Willamette River public health was but one motivating factor, and this factor was . linked more closely to the value of the river as a source for both livelihood and recreation than as a water supply. The evidence that Willamette River pollution abatement advocates were motivated by a mixture of public health, economic, and recreational concerns by the mid-1920s accords with developments in states such as Connecticut. ${ }^{54}$ However, it contrasts with the history of water pollution abatement efforts in other states. For example, in Pennsylvania in the 1920s the state's first water pollution regulations stemmed from conflicts between the coal and railroad industries that centered on economic issues, and in Maine economic arguments predominated until the early 1950 s. $^{55}$

Expressing an opinion that rings astonishingly prescient, in September 1925 an editor at the Oregonian lauded the city council for its decision to seek the assistance of the USPHS in the matter of the Willamette River survey. Although "no finally remedial action may be taken for years, owing to the heavy expense of correction," the editor opined, it was good "for the city to familiarize itself with the facts and the details. Eventually it must face the question, and settle it, or so it appears to competent observers. ${ }^{56}$ Pollution abatement efforts in the following decades would bear this out.

\footnotetext{
${ }^{1}$ For an analysis of the changing and often conflicting conceptions and uses of the Willamette River by Euro American settlers from the early nineteenth century through the 1990s, see William G. Robbins, "Willamette Eden: The Ambiguous Legacy," Oregon Historical Quarterly 99:2 (Summer 1998), 189218. For more on the importance of the river for Portland residents in terms of both economics and in providing a sense of place, see Carl Abbott, Portland: Planning, Politics, and Growth in a Twentiethcentury City (Lincoln, Nebr., University of Nebraska Press, 1983), 11-21, 30-31.
} 
${ }^{2}$ Casey Short, Water: Portland's Precious Heritage (Portland, Oreg., City of Portland, 1983), 9. See also Rick Harmon, "The Bull Run Watershed: Portland's Enduring Jewel," Oregon Historical Quarterly 96:2/3 (Summer/Fall 1995), 242-270.

${ }^{3}$ Short, Water, 14-33. As was the case in Portland, efforts to establish municipal water supplies in other U.S. cities were related to water quality issues as well as the Progressive Era push for administrative efficiency; see Martin V. Melosi, The Sanitary City: Urban Infrastructure in America from Colonial Times to the Present (Baltimore, Md., Johns Hopkins University Press, 2000), 73-89, 117-147.

${ }^{4}$ Eugene Water and Electric Board (EWEB), "An Oregon Natural Step Network Case Study” (Eugene, Oreg., EWEB, Nov. 2001), http://www.ortns.org/documents/eweb_000.pdf, and "An EWEB timeline," http://www.eweb.org/about/who/history/timeline.htm, both accessed Aug. 20, 2008. See also "Eugene Typhoid Epidemic Due To Carelessness of City Officials and Water Company, Says State Board of Health," Morning Oregonian, March 28, 1906, p. 8.

${ }^{5}$ http://www.ci.corvallis.or.us/, accessed Aug. 20, 2008.

${ }^{6} \mathrm{http}: / /$ www.cityofalbany.net/publicworks/water/index.php; http://www. mvonline.com/founders/ founders-02.html; and S. M. Griffith, "Santiam Canal Water Quality Analysis for Organic and Inorganic Nitrogen and Other Chemical Constituents," http://cropandsoil.oregonstate.edu/scedext/Pub/2004/31.pdf, all accessed Aug. 20, 2008.

${ }^{7}$ http://www.salemhistory.net/places/salem_water_department.htm, accessed Aug. 20, 2008. See also Frank Mauldin, Sweet Mountain Water: The Story of Salem, Oregon's Struggle to Tap Mt. Jefferson Water and Protect the North Santiam River (Salem, Oreg., Oak Savanna Publishing, 2004).

${ }^{8}$ See John Duffy, The Sanitarians: A History of American Public Health (Urbana, Ill., University of Illinois Press, 1990), and Melosi, The Sanitary City, for the evolution of public health and sanitary engineering practices in the United States.

${ }^{9}$ Duffy, The Sanitarians, 152-153.

${ }^{10}$ See "Public Health Division: Agency History," Oregon Blue Book, http://bluebook.state.or.us/ state/executive/health/healthhistory.htm, accessed Sept. 1, 2008; Duffy, The Sanitarians, 4. For the Oregon State Board of Health's eradication of typhoid in drinking water supplies, see "Oregon's Conquest of Typhoid," Oregonian, Apr. 27, 1941, magazine section, p. 2.

11 "The Water Problem," Morning Oregonian, Feb. 28, 1906, p. 8.

12 "Germs in Rivers," Morning Oregonian, Aug. 17, 1906, p. 14.

${ }^{13}$ See Abbott, Portland, 49-52. Portland's population in 1910 was 207,214, and in 1930 it was 301,815; for these figures, see U.S. Bureau of the Census, Census of Population: 1950 Oregon-Volume II, Part 37, Characteristics of the Population, Number of Inhabitants, Oregon, 12, available at http://www.census.gov/prod/www/abs/decennial/1950.htm, accessed Oct. 6, 2008.

${ }^{14}$ Melosi, The Sanitary City, 172.

15 “Sewage Laws Needed," Morning Oregonian, May 4, 1911, p. 7.

16 "Oregon Department of Fish and Wildlife: Agency History," available at http://bluebook.state.or.us/ state/executive/Fish_Wildlife/fish_wildlife_history.htm, accessed Jan. 31, 2009.

17 "Oil Waste Kills Fish," Morning Oregonian, July 20, 1911, p. 11.

${ }^{18}$ For more on the life of William L. Finley to the 1930s, see Lawrence M. Lipin, Workers and the Wild: Conservation, Consumerism, and Labor in Oregon, 1910-30 (Urbana, Ill., University of Illinois Press, 2007), particularly 51, 54-60. For Finley's involvement in the IWLA, see Appendix B of this thesis.

19 "Oil Waste Kills Fish," p. 11.

${ }^{20}$ For more on the role of the Oregon Fish Commission, see Lipin, Workers and the Wild, 55-56.

${ }^{21}$ See, for example, "The Beautiful Willamette," Oregon Daily Journal, Feb. 22, 1921, p. 6. 
22 “127 Are Baptized," Morning Oregonian, July 31, 1914, p. 12; "Six Enter Trial Swim,” Morning Oregonian, July 27, 1914, p. 8. See also "Some of Us Are Still Wearing. Our Woolens but the Bathing Girls Have Opened Season," Oregon Sunday Journal, May 7, 1916, sec. 2, p. 3.

${ }^{23}$ See "School Swimmers Carry Off Honors," Sunday Oregonian, July 31, 1921, sec. 2, p. 2.

24 "Bathers Line River," Sunday Oregonian, Aug. 15, 1915, sec. 2, p. 14.

${ }^{25}$ See "Sewer Objection Upheld," Sunday Oregonian, May 28, 1922, sec. 1, p. 14.

${ }^{26}$ For more on the practical applications of the concepts of "assimilative capacity" and "reasonable use," see, in particular, Melosi, The Sanitary City, 161-165, Joel A. Tarr, The Search for the Ultimate Sink: Urban Pollution in Historical Perspective (Akron, Ohio, University of Akron Press, 1996), 159178, and Arn Keeling, "Urban Waste Sinks as a Natural Resource: The Case of the Fraser River," Urban History Review 34:1 (2005), 58-70.

27 "A River in a City," Portland Telegram, Nov. 8, 1922, p. 6. Geographer Arn Keeling has found a similar relationship of the residents of Vancouver, B.C., to their urban river, the Fraser; see Keeling, "Urban Waste Sinks," 60.

${ }^{28}$ For an analysis of the changing perceptions of another Pacific Northwest river, the Skagit of northwest Washington, see Linda Nash, "The Changing Experience of Nature: Historical Encounters with a Northwest River," The Journal of American History 86:4 (March 2000), 1600-1629. In the case of the Skagit, water impoundment, channelization, and related physical changes were the primary considerations, rather than water pollution, but the underlying "reasonable use" concept Nash identifies applied to the Willamette as well.

${ }^{29}$ For example, see Portland City Commissioner Robert Dieck's call for a comprehensive sewage plan between the city of Portland and Multnomah County in "New Sewer Plan Is Recommended," Sunday Oregonian, Oct. 1, 1916, sec. 1, p. 16. For Portland city planning efforts, see Abbott, Portland, 71-92.

30 "Sewage Basins Wanted," Sunday Oregonian, Aug. 3, 1924, sec. 1, p. 13.

${ }^{31}$ See "City Quarantine on Dips in River May be Adopted," Oregon Daily Journal, July 24, 1924, p. 2, and "Windemuth Water Declared Impure," Morning Oregonian, July 16, 1924, p. 8.

${ }^{32}$ Chapters 183 and 264, General Laws of Oregon, 1919, pp. 264-266, 384-437.

33 "An Act to Promote Drainage for Agricultural and Sanitary Purposes," General Laws of Oregon, 1889, 25-28; "An Act to Amend Section 1982 Title II, Chapter X, of the Laws of Oregon, as Compiled and Annotated by W. Lair Hill, relating to Crimes against the Public Health," General Laws of Oregon, 1889, p. 29; Chapters 8 and 45, General Laws of Oregon, 1911, pp. 27 and 66.

${ }^{34}$ Jouni Paavola, "Interstate Water Pollution Problems and Elusive Federal Water Pollution Policy in the United States, 1900-1948," Environment and History 12:4 (2006), 436, 442, 447.

${ }^{35}$ Chapter 153, General Laws of Oregon, 1921, pp. 267-303. For agency reorganization, see "Oregon Department of Fish and Wildlife: Agency History."

36 "Water Pollution Topic," Morning Oregonian, July 29, 1925, p. 11. The range "four to six millions of dollars a year" in 1925 is approximately $\$ 39$ to $\$ 60$ million in 2007 . This comparison is computed using the Gross Domestic Product (GDP) deflator formula; see "Six Ways to Compute the Relative Value of a U.S. Dollar Amount, 1774 to Present" for both an explanation of this method and a comparison calculator; http://www.measuringworth.com/uscompare/, accessed Oct. 3, 2008.

37 "Hydra-Headed Pollution," Morning Oregonian, July 30, 1925, p. 10. See also "The Cities Against Stream Pollution," Morning Oregonian, Feb. 1, 1926, p. 10. For specifics on the impact of Chicago's reversal of the flow of the Illinois river, see Craig E. Colten, "Illinois River Pollution Control, 19001970," in Lary M. Dilsaver and Craig E. Colten, eds., The American Environment: Interpretations of Past Geographies (Lanham, Md., Rowman \& Littlefield, 1992), 193-214.

38 "Sewage Survey Planned," Morning Oregonian, Aug. 19, 1925, p. 9.

39 “'Willamette River Water To Be Given Test," Oregon Daily Journal, Feb. 2, 1926, pp. 1, 15. 
${ }^{40}$ H. B. Hommon, Sanitary Engineer, U. S. Public Health Service, "Report on the Pollution of the Willamette River," Feb. 26, 1926, file Stream Pollution, box 24, Master Fish Warden's Correspondence, Oregon State Archives, Salem, Oreg.

41 "Public Health Division: Agency History."

${ }^{42}$ For details of the Laurgaard waterfront development plan, see E. Kimbark MacColl, The Growth of a City: Power and Politics in Portland, Oregon, 1915-1950 (Portland, Oreg., The Georgian Press, 1979), 315-320; see also Abbott, Portland, 105.

${ }^{43}$ Olaf Laurgaard, "American Society of Civil Engineers (ASCE) Paper on Front Ave. Intercepting Sewer: Treatise on the Design, Test, and Construction of the Front St. Intercepting Sewer and Drainage System in Portland, Oregon," ca. 1933, record AF/50304, file 1-3, box 1, Public Works Administration City Engineer's Historical/Subject Records, City of Portland Stanley Parr Archives \& Records Center, Portland, Oreg.

44 "Expert Advice Sought," Morning Oregonian, Sept. 17, 1925, p. 16, and "River Pollution Topic," Morning Oregonian, Sept. 18, 1925, p. 18. For support of this initiative by editors at the Oregon Journal, see "Dirty Rivers," Oregon Daily Journal, Aug. 27, 1926, p. 16.

45 "Willamette River Water To Be Given Test," Oregon Daily Journal, Feb. 2, 1926, pp. 1, 15.

46 "Sewage Problem Hard," Morning Oregonian, Aug. 7, 1925, p. 17.

${ }^{47}$ Sewerage infrastructure is composed of five main components. Lateral sewer lines run along streets and collect wastes from homes, businesses, and other sources. These lateral lines run in to larger trunk sewers, which then flow into still larger interceptor sewers. Sewage is then directed to sewage treatment plants, the fourth component, or to outfalls. A final basic component are the pumping stations necessary to overcome inclines specific to area geography.

${ }^{48}$ See Melosi, The Sanitary City, 8-14.

49 "Fish Body Indorses Anti-Sewage Stand," Morning Oregonian, Feb. 10, 1926, p. 21.

50 "Fish Killed by Sewage," Morning Oregonian, May 5, 1926, sec. 2, p. 1.

51 "Fish Killed by Sewage."

${ }^{52}$ International Joint Commission, "Who We Are," http://www.ijc.org/en/background/ijc_cmi_ nature.htm, accessed Jan. 27, 2009.

53 Jennifer Read, “'A Sort of Destiny': The Multi-Jurisdictional Response to Sewage Pollution in the Great Lakes, 1900-1930," Scientia Canadensis 22-23:51 (1998-1999), 103-129.

${ }^{54}$ John T. Cumbler, "Conflict, Accommodation, and Compromise: Connecticut's Attempt to Control Industrial Wastes in the Progressive Era," Environmental History 5:3 (2000), 316, 320-321.

${ }^{55}$ For Pennsylvania, see Nicholas Casner, "Polluter versus Polluter: The Pennsylvania Railroad and the Manufacturing of Pollution Policies in the 1920s," Journal of Policy History 11:2 (1999), 179-200; for Maine, see Richard W. Judd, "The Coming of the Clean Waters Acts in Maine, 1941-1961," Environmental History Review 14:3 (Fall 1990), 51-74.

56 “Considering Sewage Disposal," Morning Oregonian, Sept. 18, 1925, p. 12. 


\section{CHAPTER 2}

\section{“ANTIPATHY FOR EVIL":}

\section{Advocates Push to Strengthen State Water POllution LaWs, 1926 to 1938}

The undeniably negative environmental impacts of municipal and industrial waste disposal practices throughout the Willamette Valley spurred state officials and concerned citizens to push to enhance the state's ability to control water pollution. A large fish kill downriver from Eugene in early May 1926 and the city of Milwaukie's ongoing attempts to direct yet more untreated sewage into the Willamette provided graphic examples of the ineffectiveness of state laws enacted in 1889, 1911, and 1919, and the 1921 legislative reorganization of the fish and game commissions. Pollution abatement advocates were also trying to convince Portland officials to improve the city's sewage infrastructure. Compounding increases in valley population and industrialization were geographic, hydrologic, and seasonal factors that caused pollution to accumulate in Portland's harbor and increased overall pollution concentrations in the late summer and early fall.

The first organized action: The Oregon Anti-Stream Pollution League

Representatives of the Oregon Fish and Game commissions held a meeting in May 1926 to pursue a broad-based approach to the issue and initiate research. ${ }^{1}$ Following this, in September the Oregon attorney general and State Board of Health held a conference of municipal and state officials and representatives from industries, 
civic organizations, and sportsmen's groups. Attendees at this meeting, hosted by the Salem Chamber of Commerce, formed the Oregon Anti-Stream Pollution League (ASPL). The A-SPL was not an official state body, but it did include representatives from the state Fish and Game commissions, municipalities, industries, chambers of commerce, and conservation groups. Portland's mayor George Baker and city engineer Olaf Laurgaard were members, as were State Game Warden Edgar F. Averill and Portland attorney John C. Veatch. Averill and Veatch were also both members of the Portland Chapter of the Izaak Walton League.

The Anti-Stream Pollution League was the earliest example in Oregon of a phenomenon that scholars have observed across North America. In his analysis of water pollution abatement in Vancouver, British Columbia, geographer Arn Keeling finds that "pollution is a geographical problem: it transcends the human boundaries superimposed on natural systems, entwining people and places across space through imagined and experienced geographies of environmental degradation." ${ }^{2}$ Historians Richard W. Judd and Christopher S. Beach identify regional coalitions focused on water pollution in both Oregon and Maine. ${ }^{3} \mathrm{~A}$ broad range of individuals felt the negative effects of water pollution and, because of this, initiated local and regional attempts to build coalitions and develop solutions.

The A-SPL pushed for all cities in Oregon to adopt sewage treatment programs within two years and build these facilities within a decade; they requested similar plans from industry. ${ }^{4}$ The league went beyond Oregon's 1919 water pollution laws by establishing a specific timetable for compliance and by insisting that municipalities 
build sewage treatment plants, not just sewer systems collecting and discharging wastes into streams and rivers. To achieve their goals, A-SPL members began preparing a report and a bill for the January 1927 legislative session. They also initiated a four-month educational campaign to build momentum among the general public. $^{5}$ Aware of the daunting task, A-SPL member Dr. Frederick D. Stricker, Secretary of the State Board of Health, admitted that "We cannot make the waters of all the streams in the state fit for drinking, but we can make them fit for fish and fairly fit for bathing." ${ }^{\prime 6}$ This admission illustrates the pragmatic approach of abatement advocates and accords with the "reasonable use" concept that guided such decisions among public health and sanitary engineering professionals. ${ }^{7}$

Earlier in the summer of 1926, representatives from the Crown Willamette, Oregon, and Hawley pulp and paper companies admitted that their facilities discharged both sulfite waste liquors and some wood pulp into the river. These industry representatives asserted that "the former ... was released in negligible quantities and the latter was unavoidable." Regardless of the amount of effluent, they did not believe the wastes to be injurious to fish life. Even if the wastes were proven to be harmful, however, industry representatives asserted that they could do no more because they had already reached "the practical limit" in abating discharges. ${ }^{8}$ The substance of these arguments from the pulp and paper industry would remain consistent through at least the early 1960s.

Water pollution had gained the attention of state officials, civic groups, industries, and members of sportsmen's organizations, but not the general public, as 
abatement advocates lamented. In conjunction with stream surveys and abatement plans, attendees at the September 1926 meeting that spawned the A-SPL stressed the need for a public education campaign to "stimulate that antipathy for evil which is the foundation of every necessary reform." Anti-Stream Pollution League members saw public education led by newspapers and conservation groups as the primary way to stimulate interest that could translate into support for infrastructure funding measures and increase pressure upon municipalities and industries to develop abatement plans. ${ }^{9}$

By late September, the A-SPL advocated for the comprehensive river survey methods USPHS sanitary engineer Hommon proposed in February. These methods sought to gather quantitative data on the topic for the first time, which included estimating Willamette Valley population growth rates and the resulting volume of sewage, measuring river flow and seasonal fluctuations, and securing water samples to establish dissolved oxygen, biological oxygen demand, and bacteria counts. ${ }^{10}$

In mid November 1926, Oregon State Sanitary Engineer George M. McDaniel began testing the Willamette River above Portland. The Anti-Stream Pollution League sponsored the study, in cooperation with the State Board of Health, Game and Fish commissions, and the Multnomah Hunters' and Anglers' Club. McDaniel's tests were "not cheering," the Oregonian reported, because "the stream is so polluted at several points that an average rapid sand water filtration plant would be unable to purify the river water for drinking purposes." McDaniel stressed that "Public health is considered first ... and then comes the sportsmen's outlook for game fish in the future." ${ }^{11}$ This 
sentiment reflected not only the priorities of the A-SPL, but also of public health officials and sanitary engineers generally. ${ }^{12}$

League members referenced the full results of McDaniels' survey in early December 1926 in their push to create a state water quality agency. The A-SPL's proposed legislation would compel municipalities and industries to begin construction on treatment facilities within ten years. It would also create a state department of sanitation tasked with facility approval and inspection and regulation enforcement. ${ }^{13}$ This approach was based on legislation in Pennsylvania, Massachusetts, Wisconsin, and other states. ${ }^{14}$

Newspapers in Albany, Corvallis, and Roseburg were among those expressing strong and immediate opposition to the A-SPL's proposal. These critics asserted that that there had been insufficient discussion of the economic impacts on industries and that cities would be hard-pressed to finance the required infrastructure. ${ }^{15}$

At a meeting of the State Game Commission on January 14, 1927, Portland Mayor Baker-himself a member of the Anti-Stream Pollution League—could not support the measure because he predicted that it would cost the city $\$ 35$ million. ${ }^{16} \mathrm{An}$ industry representative opined that the proposed legislation, if enacted, "would drive industry from the state" because of the costs. Faced with such pressure, the A-SPL's executive committee backed off, advocating that the state legislature appropriate the funds necessary for the Oregon State College Engineering Experiment Station ${ }^{17}$ to conduct a comprehensive pollution survey of the entire Willamette River and for the League of Oregon Cities ${ }^{18}$ to study financing options. Withdrawal of the A-SPL's 
proposal shelved a plan to create a state agency dedicated to enforcing water quality standards and to require municipalities and industries to build waste treatment plants.

The OSC Engineering Experiment Station published its Preliminary Report on the Control of Stream Pollution in Oregon in March 1929, with financial and other help from the A-SPL, Oregon Game and Fish commissions, and the Oregon Board of Health. ${ }^{19}$ This report expanded upon surveys conducted since 1926 by the Portland City Club, the Portland City Bacteriological Department, the State Sanitary Engineer, and the League of Oregon Cities. ${ }^{20}$ The 1929 report was different from previous research-not in its findings, which were in accord with the others-but that it was the first time state agencies had helped initiate such a study.

The OSC Engineering Experiment Station's 1929 preliminary report outlined an approach to gather quantifiable data to evaluate river quality in relation to drinking water supplies, the commercial value of the fishing industry, the recreational value of sports fishing, and the natural beauty of rivers and streams. It also summarized data about fluctuating seasonal water flow and how this irregular flow contributed to declines in water quality, an important consideration in determining water pollution causes and solutions. Decreased rainfall and snow melt between June and September diminished flow, which resulted in an overall concentration of pollutants during the summer. Water quality scientists believed that "streams tend[ed] to purify themselves through certain natural phenomena" such as dilution and aeration. These natural purification processes, however, were inadequate in cases of excessive pollution concentrations. Seasonal low water flows and increased use of the Willamette River as 
a waste sink concentrated the sulfite liquors, untreated sewage, and other effluents that decreased dissolved oxygen levels and increased bacterial counts. ${ }^{21}$

Attendees at the March 1929 Commonwealth Conference in Eugene were aware of the findings of the OSC Engineering Experiment Station report. ${ }^{22}$ They were also presented with arguments that pollution of Oregon's streams risked the loss of future economic benefits based on increased recreation and tourism and the needs of industries seeking clean water for their operations. ${ }^{23}$ Contradicting the findings of U.S. Public Health Service sanitary engineer H. B. Hommon's three-year Willamette River pollution survey published earlier in March, Washington State Sanitary Engineer H. W. Nightengale called the pollution of the Willamette a serious threat to both the public health and the economy. Nightengale drew specific attention to the sluggish flow of the river that concentrated pollutants during the summer and early fall. ${ }^{24}$

While all participants did not agree on the full economic impacts of water pollution, they were able to find some common ground. On the closing day of the conference, attendees reached a consensus to create a statewide body to address water pollution. This consensus echoed the earlier call of the Anti-Stream Pollution League and reflected research in the OSC Engineering Experiment Station's preliminary report on steps taken in other states. Reflecting the need for cooperation, attendees agreed that this body should be staffed by sanitary engineers, industry officials, and state agency representatives. This policy position reflected the diverse perspectives of conference attendees who included representatives of industry, government, Oregon 
universities, and sportsmen and conservation organizations. ${ }^{25}$ Such consensus did not, however, spur the state legislature to action.

The momentum to address the issue of state-wide water pollution continued into the early 1930s. The A-SPL itself faded into the background by the end of the 1920s, but individual members of this group continued to push for Willamette River pollution abatement in their capacities as members of the Izaak Walton League, State Fish or Game commissions, State Board of Health, and other groups. ${ }^{26}$ Portland city officials and pulp and paper industry representatives challenged these efforts and continued to balk at project costs and at what they perceived as the excessively prohibitory nature of legislative proposals. ${ }^{27}$ The Willamette became more polluted as these disagreements continued. ${ }^{28}$

Water pollution as a matter of state and federal resource management: Oregon's Advisory Committee on Stream Purification

Observers at the local, state, and federal levels were aware that conditions along the entire length of the Willamette River were worsening by the mid-1930s. Reflecting this, in 1931 the state legislature again reorganized the State Fish and Game commissions, placing water quality issues that threatened aquatic life or domestic water supplies under the purview of Game Commission agents. ${ }^{29}$

Attempting to address the city's discharge of untreated sewage, in 1933 and 1934 Portland city officials tried to devise infrastructure specifications, develop 
funding schemes, and apply to federal agencies for financial assistance as part of President Franklin D. Roosevelt's New Deal. ${ }^{30}$ The Roosevelt Administration considered water quality an important part of a comprehensive regional planning and resource management program; with the influx of federal research and funding assistance, state, regional, and national planning agencies included Willamette River pollution as an important natural resource management issue. ${ }^{31}$ Water pollution had reached a new level of importance for federal and state officials, and this was particularly apparent in a significant increase in federal funding for urban sewerage infrastructure projects. ${ }^{32}$ In Portland's case, however, insufficient engineering specifications, problems securing federal Public Works Administration funding, and the failure of the city to pass necessary bond issues stymied progress. ${ }^{33}$

Water pollution increased without resolution of Portland's discharge of raw sewage. In 1935 the Columbia River Fishermen's Association threatened to bring suit against municipalities and industries from Eugene to Astoria for damage fisheries suffered as a result of the unsanitary state of the river. ${ }^{34}$ A state law enacted in 1927 authorized the Fisherman's Association, as the aggrieved party, to bring suit against polluters of waterways in any dirainage west of the Cascade Mountains. ${ }^{35}$ In summer 1936, the Oregon Journal published a letter from G. F. McDougall of Portland who noticed the seasonal appearance of sewage sludge banks along the shores of the Willamette. McDougall found that these accumulations worsened "at times of unusually low water [when] they become exposed and fester in the sun" and then attract swarms of flies potentially carrying disease ${ }^{36}$ Frank Bell, Commissioner of the 
U.S. Bureau of Fisheries, wrote to Oregon State Game Supervisor Frank Wire in early 1936 that he had received "a considerable number of letters in which protests were made against the pollution of the Willamette River." ${ }^{37}$

As pollution abatement advocates reacted to environmental degradation in their midst, they benefitted from expertise, examples, and assistance from beyond Oregon. In the 1920s, Anti-Stream Pollution League members had drawn upon precedents established in Massachusetts, Pennsylvania, and Wisconsin, as well as Public Health Service and Bureau of Fisheries studies. In the early and mid 1930s, state abatement advocates attempted to take advantage of New Deal infrastructure financing and were offered specialists and equipment from the Bureau of Fisheries. ${ }^{38}$ David Charlton was in contact with specialists across the country since at least 1936, including L. F. Warrick, Wisconsin State Sanitary Engineer, whom he contacted regarding recent publications and progress reports from that state's Committee on Water Pollutíon. ${ }^{39}$ In addition to research assistance and sewage infrastructure funding, beginning in 1935 the federal government provided another important resource: regional planning assistance through the National Resources Committee (NRC). President Roosevelt created the NRC in June 1935 to provide assistance to state planning boards conducting research into drainage basin hydrology, soils, and flora, and to help states disseminate this information to the public. ${ }^{40}$ The NRC organized the country into regional planning areas. The Oregon State Planning Board (OSPB) joined similar bodies in Washington, Idaho, and Montana within the Pacific Northwest Regional Planning Commission (PNWRPC). ${ }^{41}$ The Oregon Legislature created the OSPB in 
1935 to provide fact finding and advisory services used to promote conservation and sustained development of the state's natural resources. ${ }^{\dot{4} 2}$ Though water pollution was one topic among many for these planning organizations, committees within the OSPB, PNWRPC, and NRC provided leadership on the abatement issue through research, coordination, prioritization, and project funding. The OSPB created an Advisory Committee on Stream Purification (ACSP) in October 1935, which took the lead on Willamette Valley water pollution research from late 1935 until early $1937 .{ }^{43}$

Oregon State Planning Board members had created their Advisory Committee in the immediate wake of the first federal National Resources Committee report on water pollution, which concluded that pollution was outstripping efforts at abatement and urged cooperation between state agencies, municipalities, industries, and other interest groups to adopt treatment remedies to meet site- and use-specific water demands. The NRC supported maintaining water pollution abatement administration at the state level, although they recognized that interstate and international pollution issues would require federal regulation or interstate compacts. Even though the NRC linked water pollution directly to decreased recreational possibilities, degraded aesthetics, and threats to aquatic life, it found that public interest in the matter was lacking. ${ }^{44}$ The National Resources Committee's water pollution report and the creation of Oregon's Advisory Committee on Water Pollution showed that degraded water quality was undeniably a local and national concern.

The charge of Oregon's fifteen-member Advisory Committee was to coordinate and disseminate research on abatement technologies, analyze costs, and 
assess legislative options regarding municipal indebtedness and compliance enforcement. ACSP members were also to "bring together all points of view and approach all problems in a cooperative manner" while preparing recommendations for the. 1937 legislative session. ${ }^{45}$ They met for the first time in December 1935. Among the members were representatives from city and state government, industry, civil and sanitary engineering, and fish and game management. ACSP member David Charlton was one of four members who also belonged to the IWLA. ${ }^{46}$

The composition of the ACSP illustrates a key dynamic in the push to abate water pollution, a dynamic that historian Terence Kehoe describes as "cooperative pragmatism." Rather than approach the issue in an adversarial manner, advocates first looked to devise mutually agreeable solutions. ${ }^{47}$ Abatement advocates applied the cooperative pragmatic approach in reaction to repeated failures of federal and state judiciaries in the late nineteenth and early twentieth centuries to address effectively the complexities of water pollution. Adjudicated environmental conflicts could only be resolved through equity considerations, not through remediation or cessation of the activity. Issues taken to the courts also tended to perpetuate a distinct adversarial relationship between the litigants. The resulting judicial decisions, therefore, did not necessarily alleviate ongoing pollution concerns or establish procedures to mitigate against pollution occurring again. ${ }^{48}$

By the 1920s, legislatures in Pennsylvania, Wisconsin, and other states had begun transferring water pollution control authority from costly, punitive, and retroactive judicial decisions to more flexible and proactive management from city and 
state agencies dedicated to the issue. ${ }^{49}$ This shift was part of the development of professionalized state and federal institutions during the Progressive Era that also included public health administration, regional water management, and many other aspects of the modern American state. ${ }^{50}$

Movement toward the new administrative capacities exemplified in the examples of Pennsylvania and Wisconsin required developing an effective state-level legal structure for water quality control. As Oregon's state planning board directed, members of the Advisory Committee conducted extensive research on this topic. ${ }^{51}$ In February 1937, the committee chairman wrote in his report to Governor Charles H. Martin that "Oregon has enough law to make and keep our intrastate streams as pure as they were when Lewis and Clark camped on their banks, but mere law does about as much to prevent stream pollution and correct admittedly evil conditions as it does to prevent sale of intoxicating liquor and eliminate drunkards." Excessively prohibitory laws were insufficient and unpopular, this line of reasoning asserted, because they repelled citizens and industry by constraining production, recreation, and other uses of the resource. ${ }^{52}$ Also, because private citizens and industry tended to react strongly against these constraints, such laws were mostly unenforceable, not unlike Prohibition, which had been repealed just a few years previously. These laws also did not provide for proactive administration of water quality measures.

The Advisory Committee published its report on efforts to reduce stream pollution in February 1937. This report drew upon studies completed during the intervening decade and found that Willamette River pollution was getting worse. ${ }^{53}$ 
The report also echoed previous studies in finding that public interest in the matter had been muted, in part because no large communities drew their water supply from the river. Industries were not addressing the issue because they contended that externalizing their costs by using the river as a waste sink was the most economical waste disposal method. ${ }^{54}$

The ACSP produced its preliminary industrial pollution survey in June 1937. The committee sent questionnaires to pulp, timber, canning, textile, and other industries to discern abatement steps underway and secure accurate data regarding the kinds and amounts of solid and liquid wastes produced. ${ }^{55}$ Concluding that "pollution of Oregon's streams is increasing," the committee called for "an intensive study of each plant ... to determine feasible and economic means of treating its wastes that are deleterious to streams." Further, the report concluded that "The Willamette should be an important recreational asset," not just an industrial and municipal waste sink. Though "little used as a source of domestic water supply," the river served as important spawning grounds for fish harvested commercially at the mouth of the Columbia. The report postulated that this resource could also be the basis for an important recreational fishing industry serving visitors and positively impacting local economies. $^{56}$

Pollution abatement advocates recognized the need for flexibility and adaptability to local situations, if there was to be any progress in convincing cities and industries to cease using the Willamette as a receptacle for untreated wastes. Municipal infrastructure, geography, and changing demographics, for example, 
influenced sewage concentrations that, in turn, set the parameters for infrastructure needs. Concentrations and amounts of sulfite effluent from pulp and paper mills could also vary widely, based on production requirements. Although there were at least 1,500 sulfite liquor waste treatment patents filed by 1933 , none of these patents had yet proven to be economically feasible because of variation in the industry. Further, even if sewage and sulfite wastes had been treated, there were not any consistently effective ways of disposing of sludge and other residues ${ }^{57}$ Faced with such complexities, advocates sought cooperative approaches to develop economically feasible measures. ${ }^{58}$

Both the Anti-Stream Pollution League in the late 1920s and the Advisory Committee on Stream Purification in the mid-1930s grappled with issues related to an unwieldy and inadequate legal structure, the high costs of waste-treatment systems, and insufficient waste-treatment technologies. As an essential aspect of its work, the Advisory Committee produced four reports providing data on state and federal water pollution control to legislators such as Senator Byron Carney of Milwaukie. ${ }^{59}$ With this information, Carney drafted a water pollution abatement bill for the 1937 legislative session. ${ }^{60}$ In early 1937 , with the work of the committee complete, leadership in Willamette River pollution abatement shifted to Senator Carney and others. $^{61}$ 
Governor Martin's veto helps spur creation of the Oregon State Sanitary Authority

With information from the Advisory Committee on Stream Purification, Senator Carney crafted and submitted a bill to his colleagues in late February 1937. Carney's Senate Bill (S.B.) 392, similar to the 1927 proposal of the Anti-Stream Pollution League, proposed creation of a state sanitary commission. This commission would include the state's sanitary engineer, health officer, master fish warden, a member of the game commission, and a member of the general public. In accordance with the summary of effective regulations in other states outlined in the OSC Engineering Experiment Station preliminary report of 1929, these agents would carry out the bill's provisions including approving sewage system plans, pursuing individual, municipal, and corporate violators, and allocating state and federal water quality program funds. The commission also had authority to conduct research, disseminate information, and foster cooperation among individuals, cities, and businesses. S.B. 392 also established public policy of the State of Oregon to preserve "the natural purity of navigable and other streams and of the lakes and coastal waters" for public health, recreation, and the conservation of fish and migratory birds. ${ }^{62}$

State Senators requested relatively minor amendments to Carney's S.B. $392 .{ }^{63}$ However, Carney withdrew S.B. 392 entirely and on March 3 submitted in its stead S.B. 414. This new bill included the public policy goal of maintaining the "natural purity" of the state's waters and provided for court injunction of polluting practices in much the same way as S.B. 392 . However, S.B. 414 was much less robust than its 
predecessor, because it did not centralize authority for maintaining water quality within a state agency. ${ }^{64}$ Carney's revised measure passed both houses on March $8 .{ }^{65}$ The Oregon Journal lamented that S.B. 414 had "lost its teeth" by not creating a state sanitary commission: "It would be a stimulative thing in Oregon," the Oregon Journal asserted, "to see an official agency armed both with the authority and duty to set out actually to abate pollution as the public nuisance for which it is."

Four days later, Governor Martin vetoed Carney's de-toothed bill. Martin concluded that the measure had been passed hurriedly, without proper consideration, and was also discriminatory for two reasons. First, it identified pollution as "sewage or any other noxious or deleterious substances by any municipal corporation" only [italics mine], while it included no provision for treatment of industrial or other wastes. Second, Martin found the bill to place an undue financial burden on municipal taxpayers. Citing the projected $\$ 15$ to $\$ 18$ million costs of Portland's proposed sewage disposal infrastructure, Martin predicted that taxpayers in Portland and other municipalities would "unquestionably attack the act for its unjust discrimination."67 One critic of the veto asserted that Portland city officials influenced Governor Martin's decision, because the legislation "put Portland in the tender spot of doing something before the taste of a rejected bond issue for sewage disposal was out of its mouth," a reference to the city's repeated failures to pass sewer funding bond measures and secure federal public works funding in 1933 and $1934 .^{68}$

Pollution abatement advocates came together in the weeks following Governor Martin's veto to push again for changes to state laws and administrative structures. 
These efforts were centralized in a new organization, the Oregon Stream Purification League.

Members of Oregon Business \& Investors, Inc., created the Oregon Stream Purification League (OSPL) on May 8, 1937, in the aftermath of a water pollution hearing held in Portland by the U.S. Bureau of Fisheries. ${ }^{69}$ Oregon Business \& Investors was a group of business, government, and civic leaders concerned with issues of legislation and taxation. ${ }^{70}$ As a special committee within this organization, the Stream Purification League was composed of influential leaders in conservation and state governance, such as State Treasurer Rufus C. Holman, Senator Frank Franciscovich, and naturalist William Finley. ${ }^{71}$ These people created the OSPL to continue the work of abating water pollution in the wake of Governor Martin's veto because of a "deep-rooted interest in the matter under consideration" on the part of a growing number of Oregon citizens. ${ }^{72}$

The shift in leadership on water pollution abatement to the Oregon Stream Purification League in early 1937 indicates persistent and worsening conditions that frustrated an increasingly diverse group of men and women. Over the preceding decades, water pollution in Oregon and other states had grown from a concern voiced almost solely by sportsmen and public health and sanitary engineering professionals in the 1910 s to include a much more broad-based coalition by the mid-1930s. ${ }^{73}$ Along the Willamette River, the issue of water pollution involved public health, economic, aesthetic, and moral concerns, a realization that adds important shades of complexity 
to some scholars' assertions that early twentieth-century clean streams advocates were concerned with either public health or broader conservation issues. ${ }^{74}$

Reflecting this complexity, members of women's groups and teacher's organizations attended the inaugural meeting of the league, joining public health professionals, sanitary engineers, conservationists, and others long involved in the issue. A representative of the Columbia River Fishermen's Association was also at this meeting to provide graphic evidence of the fouling of fishing nets in the lower Columbia from slime. Speaking from direct experience, he also reported that the negative impact on aquatic life from sewage-much of it from Portland-was "no joke." 75

OSPL members focused on "centering public opinion" in the short term, and in the long term they sought to "enlighten the next session of the legislature." League leaders stated that it was not their intention to usurp the authority of the State Board of Health and the State Fish and Game commissions, agencies long engaged in the issue. Rather, the group sought to include "as many women as there are men," to educate the public, and to "consolidate all of the diverse activities of the many existing but separate organizations" specifically on the issue of abating municipal sewage. ${ }^{76}$

In stressing the issue of sewage abatement, OSPL members were focusing the league's energy on a highly visible kind of point-source pollution amenable to treatment for three important reasons. First, sewage treatment technologies were much more advanced than industrial effluent treatment systems, making the former more practical to address. Second, municipalities were eligible for many kinds of federal 
assistance including infrastructure funding from the Public Works Administration and Works Progress Administration, planning aid from the National Resources Committee, and survey work by the Public Health Service and Bureau of Fisheries. Finally, the democratic process made city and state government officials more open to input and influence from advocacy groups, in contrast to the less accessible hierarchies of private business firms such as pulp and paper companies. For these reasons the OSPL was much more likely to build consensus among its diverse membership and the general public on the issue of sewage treatment, and to thereby influence city and state governments.

Seeing the creation of the Oregon Stream Purification League as a positive development, the Oregon Journal asserted that any opposition to the work of this group "might be principally on the part of large community and industrial interests that find it temporarily cheap to pour raw sewage and mill waste into streams." The editorial called upon all citizens to follow the example of Columbia River fishers and support pollution abatement, and closed with the cheer, "All power to the newly organized Oregon Stream Purification League!"77

To enlighten state legislators, a committee of the OSPL worked throughout 1937 to draft a clean-streams initiative for the November 1938 ballot. Senator Byron Carney chaired the committee. ${ }^{78}$ The committee finalized its draft citizen's initiative in mid September 1937. The proposal was similar to Carney's S.B. 392 and the 1927 proposal of the Anti-Stream Pollution League in that it established a state-level body in charge of water quality. As with Carney's 1937 senate bills, the OSPL proposal also 
established the cleanliness of streams as Oregon public policy. These elements made the proposal significantly stronger than the state's 1889,1911 , and 1919 water pollution laws and the periodic reorganizations of the Fish and Game Commissions.

In the OSPL's draft initiative, a division of sanitation under the State Board of Health would administer water quality throughout the state. This state body would review and approve sewerage plans and specifications. It would also administer funds from state and federal agencies, such as was proposed under provisions of the VinsonBarkley bill (H.R. 2711) then being considered in Congress. ${ }^{79}$ H.R. 2711 and predecessor water quality bills proposed earlier in the decade were contentious because they sought to centralize water pollution control administration at the federal level, a move that many municipal and state leaders opposed. ${ }^{80}$

Stream Purification League members filed the initiative with the Oregon Attorney General on December 17, 1937. The Oregon Journal, Oregonian, and Oregon Voter supported the proposal for explicitly balancing the interests of municipal officials, industry representatives, conservation groups, and the general public. ${ }^{81}$ Once filed, the OSPL, Izaak Walton League, Portland Chamber of Commerce, Oregon Grange, and other advocates educated the public and gathered the requisite signatures to place the initiative on the November 1938 ballot $^{82}$

Members of the OSPL were well aware that industry was reluctant to move forward with its own pollution abatement expenditures without municipalitiesparticularly the city of Portland-moving first. Many other communities were also 
reluctant to move forward with sewage treatment plans, in spite of assistance from the Public Works Administration, as long as Portland was not making progress. ${ }^{83}$

Faced with this realization and the desire to generate employment during the Great Depression, Portland City Commissioners Ormand Bean, William Bowes, and J. E. Bennett crafted a pay-as-you-go sewage-system funding proposal for the November 1938 election. ${ }^{84}$ Commissioner Bean supported this proactive move to avoid being forced into action from "panicky demand by the people because of health conditions" or by federal and state legislative mandate. ${ }^{85}$

As the year 1938 progressed, pollution abatement advocates were increasingly active in promoting the OSPL initiative and Portland sewerage funding plan. Dr. Richard B. Dillehunt, Dean of the University of Oregon Medical School and Chief Surgeon at Shriner's Hospital, agreed to head the campaign to pass the Portland measure. Abatement advocates also invited Dr. Abel Wolman to participate. He was the leading sanitary engineering expert and Chairman of the Water Resources Committee of the federal National Resources Committee. ${ }^{86}$ Wolman had been receiving reports on Willamette River pollution for some time. He told a Portland audience on August 10 that "your river is pretty sloppy," but he saw Portland's example as proof that progress could be made without federal mandate. ${ }^{87}$ Wolman understood the proper federal role as providing research assistance, financial aid, and encouraging interstate compacts, while "administration of pollution abatement is best performed by State and interstate agencies." ${ }^{88}$ This view echoed Portland Commissioner Bean and other city officials and reflected the conservative side of 
ongoing national debates regarding the proper relationship between state and federal agencies on water pollution and other issues.

Publicity in support of the November 8 measures increased in the days leading up to the vote. Speeches, editorials, and staged media events were designed to appeal to a wide range of interests and included economic, public health, moral, and aesthetic elements. Abatement advocates found that economic arguments appealed to a broad constituency in the midst of the Great Depression. William Finley stated on October 19 that "expenditure of $\$ 12,000,000$ to clean up the pollution of the Willamette river will increase property values of the city by $\$ 50,000,000$," and newspaper editorials often referred to other economic considerations. ${ }^{89}$

Public health, moral, and aesthetic arguments in favor of pollution abatement were also represented. On October 12 , advocates placed hatchery fingerlings into baskets they lowered into the waters of Portland's harbor. As Portland's Clean the Rivers Committee member Miss Oregon Barbara Johnson looked on, these "“finny guinea pigs' were dead within 25 minutes after being placed in the poisonous waters. ${ }^{, 90}$ Two days before, Portland Mayor Joseph Carson, Jr., and other city officials toured the harbor to look at the city's exposed sewer outfalls. The Oregonian reported "large quantities of sewer gas bubbling to the surface" and "varying amounts of floating sewage" on this trip. As was the case with the fish-survival experiment, photographs of the boat tour accompanied the text. ${ }^{91}$

Following his tour, Mayor Carson authored a "Special Message" in the Oregon Journal. In reaction to his first-hand experience of the "indescribably bad" condition 
of the water, Carson opined that "sooner or later this condition must be remedied, and I believe we should wait no longer." He endorsed fully both the city and state measures as a way for voters to "demonstrate traditional Portland and Oregon solicitude for health, pride in decency and eagerness for progress." ${ }^{.92}$ As if to underscore evidence from the hatchery fingerling experiment and Mayor Carson's appeal, Portland's health officer discovered high bacteria counts, an indicator of typhus, in Willamette River water on October $14 .{ }^{93}$ The mayor initiated "Clean the Rivers Week" on October 29 for the final pre-election push. Events included a public meeting on November 2 and a parade on November 5. On November 4, Mayor Carson donned a deep-sea diver's suit and spent about one minute in approximately thirty feet of "dun-colored water" to generate three particularly entertaining photographs for the front page of the Oregonian..$^{94}$

Such graphic examples of the degraded state of the river undoubtedly influenced public opinion. Voters passed the Oregon Stream Purification League's Water Purification and Prevention of Pollution Bill by a landslide vote of 247,685 to 75,295 , thereby creating the Oregon State Sanitary Authority. ${ }^{95}$ The measure creating a pay-as-you-go funding mechanism for Portland's sewer system also passed by a wide margin. ${ }^{96}$

Reflecting on the publicity campaign a decade later, Merle J. Brown, Secretary-Treasurer of the Oregon Izaak Walton League, recollected that Wonderful impetus was given to one of the five campaigns by the nationally famous and dearly beloved Dr. Richard T. Dillehunt who teamed up with Joseph Gerber, prominent advertising executive. Under the direction of Gerber, the campaign was so 
dramatized that the people of Portland could never forget the condition of the river and the necessity for doing something about it. ${ }^{97}$

Reacting to the severe pollution of the Willamette River that curtailed accustomed activities and in response to continued legislative failures and a governor's veto, Oregon voters had overwhelmingly approved the strongest water quality measures in the history of the state. ${ }^{98}$ This came more than ten years after the pioneering work of the Anti-Stream Pollution League, efforts of the State Planning Board's advisory committee in the mid-1930s, and advocacy from a broad-based coalition represented by the Stream Purification League. At the end of 1938, Oregonians looked ahead to substantive changes in municipal and industrial waste disposal practices.

\footnotetext{
${ }^{1}$ Conferees organized themselves under the name "Oregon Anti-Stream Pollution Committee." See "Minutes of the Meeting of the Oregon Anti-Stream Pollution Committee," May 20, 1926, file Stream Pollution, box 24, Master Fish Warden's Correspondence, Oregon State Archives, Salem, Oreg. [hereafter OR State Archives]. "Stream Pollution Rouses Game Body," Morning Oregonian, May 11, 1926, sec. 2, p. 3; Fred Merryfield, "History, Progress, and Problems of Stream Pollution in Oregon," Commonwealth Review 18:1 (March 1936), 80-86; "Sewer Fight Started," Morning Oregonian, May 14, 1926, p. 13.

${ }^{2}$ Arn Keeling, "Sink or Swim: Water Pollution and Environmental Politics in Vancouver, 1889-1975," BC Studies 142/143 (Summer/Autumn 2004), 100.

${ }^{3}$ Judd and Beach, Natural States: The Environmental Imagination in Maine, Oregon, and the Nation (Washington, D.C., Resources for the Future, 2003), 36.

4 "Drive to Purify Streams Starts," Oregon Daily Journal, Sept. 21, 1926, p. 1.

5 "Foes of Pollution Organize at Salem," Morning Oregonian, Sept. 11, 1926, p. 6. See also "Pollution of Streams Is Held Menace," Oregon Daily Journal, Sept. 10, 1926, p. 1; Merryfield, "History, Progress, and Problems," 80-86.

6 "Experts Will Talk Pollution Problem," Morning Oregonian, Sept. 6, 1926, p. 18.

${ }^{7}$ Neil S. Shifrin, "Pollution Management in the Twentieth Century," Journal of Environmental Engineering 131:5 (May 2005), 676-691. See also Martin V. Melosi, The Sanitary City: Urban Infrastructure in America from Colonial Times to the Present (Baltimore, Md., Johns Hopkins University Press, 2000), 161-165, and Arn Keeling, "Urban Waste Sinks as a Natural Resource: The Case of the Fraser River," Urban History Review 34:1 (2005), 58-70.

8 "River Pollution Ban Backed, but Remedy Lacking," Oregon Daily Journal, May 20, 1926, p. 2; see also "Waste Disposal Argued," Morning Oregonian, May 21, 1926, p. 7.

9 "The Stand on Stream Pollution," Morning Oregonian, Sept. 7, 1926, p. 10.
} 
10 "Pollution of Streams," n.d., file Stream Pollution, box 24, Master Fish Warden's Correspondence, OR State Archives. Based on provenance, this unattributed 2-page typewritten summary of activities from May 1926 to mid-September was likely produced by the Anti-Stream Pollution Committee.

11 "Pollution Study Started on River," Morning Oregonian, Nov. 16, 1926, p. 14.

${ }^{12}$ For the predominance of this focus on public health above other considerations throughout North America, see Hugh S. Gorman, "Laying the Foundation for the Control of Industrial Pollution, 19301970: Two Canals, A Refinery, and Clarence W. Klassen," Journal of Illinois History 8:3 (2005), 182-208; Glenn Harris and Seth Wilson, "Water Pollution in the Adirondack Mountains: Scientific Research and Governmental Response, 1890-1930," Environmental History Review 17:4 (Winter 1993), 47-72; Jouni Paavola, "Interstate Water Pollution Problems and Elusive Federal Water Pollution Policy in the United States, 1900-1948," Environment and History 12:4 (2006), 435-465; and Jennifer Read, “'A Sort of Destiny': The Multi-Jurisdictional Response to Sewage Pollution in the Great Lakes, 1900-1930," Scientia Canadensis 22-23:51 (1998-1999), 103-129, among others.

${ }^{13}$ See "State Body to Keep Rivers Clean Asked," Morning Oregonian, Dec. 1, 1926, p. 16.

${ }^{14}$ See, generally, Paavola, "Interstate Water Pollution Problems," 442-446, and Shifrin, "Pollution Management in the Twentieth Century," 680. For specific state examples, see Nicholas Casner, "Polluter versus Polluter: The Pennsylvania Railroad and the Manufacturing of Pollution Policies in the 1920s," Journal of Policy History 11:2 (1999), 179-200, on Pennsylvania, Theodore Steinberg, Nature Incorporated: Industrialization and the Waters of New England (Amherst, Mass., University of Massachusetts Press, 1994), 205-239, on Massachusetts, and Gregory Summers, Consuming Nature: Environmentalism in the Fox River Valley, 1850-1950 (Lawrence, Kans., University Press of Kansas, 2006), particularly 19-30, on Wisconsin.

15 "Stream Pollution," Oregon Voter, 47:13 (Dec. 25, 1926), p. 11.

${ }^{16}$ \$35 million in 1927 would be approximately \$354 million in 2007.

${ }^{17}$ Hereafter OSC Engineering Experiment Station. Oregon State Agricultural College in Corvallis was later known as Oregon State College and then Oregon State University. For a general overview of the work of the Engineering Experiment Station on water quality projects, see "State College Keeps Tabs on 'Bugs' in Water Supply," Sunday Oregonian, April 5, 1931, sec. 4, p. 10.

${ }^{18}$ The League of Oregon Cities (LOC) was an organization of municipal leaders formed in January 1925 and headquartered in Eugene. In 1933 the Oregon State Board of Education organized the Bureau of Municipal Research and Service, which then became the research arm of the League. For an overview of the purpose of the LOC in their own words, see "What is the League of Oregon Cities?" League of Oregon Cities News Letter, 1947-2 (Jan. 30, 1947), pp. 1-2, binder "League Newsletters - 1947," League of Oregon Cities, Salem, Oreg.

${ }^{19}$ William L. Finley was instrumental in securing funds for the 1929 OSC Engineering Experiment Station study after failure of the A-SPL to pass legislation; see Merle J. Brown, Secretary-Treasurer, Oregon Division, IWLA, to Kenneth Reid, Executive Director, IWLA, July 22, 1947, folder Correspondence re: Water Pollution 1947-1948, box 18, David B. Charlton Papers (MSS 1900), Oregon Historical Society Research Library, Portland, Oreg. (hereafter Charlton Papers).

${ }^{20}$ C. V. Langton and H. S. Rodgers, Preliminary Report on the Control of Stream Pollution in Oregon, Bulletin Series, No. 1 (Corvallis, Oreg., Oregon State Agricultural College Engineering Experiment Station, 1929), 5-10. For excerpts of these other reports, see George W. Gleeson, The Return of a River: The Willamette River, Oregon (Corvallis, Oreg., Oregon State University Water Resources Research Institute, 1972), 13, and also "Sewage Bonds Recommended if Council Guarantees Competent Engineering," Portland City Club Bulletin, 14:11 (July 14, 1933), 1-3, in which the City Club's 1926 report was excerpted at length. See also "Time to Start," Oregon Daily Journal, May 5, 1927 , p. 14.

${ }^{21}$ Langton and Rodgers, Preliminary Report, 8; Fred Merryfield, A Preliminary Survey of Industrial Pollution of Oregon Streams (Portland, Oreg., Oregon State Planning Board, [June] 1937), 2. The 
1929 report was followed by three additional studies from the OSC Engineering Experiment Station, all of which pursued topics recommended in the earlier report and built upon its findings. For these reports, see H. S. Rodgers, C. A. Mockmore, and C. D. Adams, A Sanitary Survey of the Willamette Valley, Bulletin Series, No. 2 (Corvallis, Oreg., Oregon State Agricultural College Engineering Experiment Station, [June] 1930); George W. Gleeson, A Sanitary Survey of the Willamette River from Sellwood Bridge to the Columbia River, Bulletin Series, No. 6 (Corvallis, Oreg., Oregon State Agricultural College Engineering Experiment Station, [April] 1936); Gleeson and Merryfield, Industrial and Domestic Wastes of the Willamette Valley, Bulletin Series, No. 7 (parts 1, 2, and 3) (Corvallis, Oreg., Oregon State Agricultural College Engineering Experiment Station, [May] 1936).

${ }^{22}$ The Oregon State System of Higher Education and League of Oregon Cities sponsored yearly Commonwealth Conferences at the University of Oregon in Eugene. These conferences were generally organized around a theme and provided a venue for city, county, and state officials, subject area experts, and concerned citizens to discuss public policies and practices. Proceedings of these conferences were published in issues of the Commonwealth Review.

${ }^{23}$ For recognition of the recreational potential of the Willamette in Portland, see Edward M. Miller, "River to Lure Pleasure-Seekers and Vacationers," Sunday Oregonian, March 1, 1931, sec. 4, p. 4.

24 "River Pollution Deemed Curb to State Progress," Oregon Daily Journal, March 22, 1929, p. 22; see also Merryfield, "History, Progress, and Problems," 83. For excerpts from the U.S. Public Health Service report, see "Contamination in River Water No Health Peril," Oregon Daily Journal, March 19,1929 , p. 2.

25 "Pollution Curb Begun," Morning Oregonian, March 23, 1929, p. 10; "Stream Pollution Board to Convene," Oregon Daily Journal, June 14, 1929, p. 7. See also Merryfield, "History, Progress, and Problems," 84, for correlation of committee participants with pollution abatement research tasks.

${ }^{26}$ See, for example, "Game Board to Go After 'Polluters," Oregon Daily Journal, June 16, 1931, p. 17. For a synopsis of actions by pollution abatement advocates through the end of 1931, see "Pollution or Solution," Oregon Daily Journal, Oct. 6, 1931, p. 6.

${ }^{27}$ See, for example, "Stream Pollution Clause Under Fire," Morning Oregonian, Feb. 5, 1931, p. 5.

${ }^{28}$ See "River Source of Peril," Morning Oregonian, Nov. 15, 1930, p. 2; "Real Menace Seen in Filthy Streams," Morning Oregonian, Sept. 2, 1930, sec. 1, p. 16; "Finley Charges River Pollution at Oregon City," Oregon Daily Journal, July 25, 1930, p. 23; and "River Water Held Unfit for Bathing," Morning Oregonian, July 2, 1931, p. 26.

${ }^{29}$ Chapters 180 and 310, General Laws of Oregon, 1931, pp. 247-292, 684-728.

${ }^{30}$ Board of Review (R. H. Corey, Wellington Donaldson, Carl E. Green, and Abel Wolman), "Report on the Collection and Disposal of Sewage," Portland, Oreg., Aug. 19, 1939 [hereafter Wolman Report], 5-7, in folder 8402-01 Sewage Disposal Project-Sewage Collection and Disposal Report 1939, box 1, Public Works Administration-City Engineer's Historical/Subject Records, City of Portland Stanley Parr Archives and Records Center, Portland, Oreg. [hereafter SPARC].

${ }^{31}$ National Resources Committee, Progress Report with Statements of Coordinating Committees (Washington, D.C., U.S. Government Printing Office, June 15, 1936), 33.

${ }^{32}$ Terence Kehoe, Cleaning Up the Great Lakes: From Cooperation to Confrontation (DeKalb, Ill., Northern Illinois University Press, 1997), 24-25.

${ }^{33}$ For overviews of Portland's funding and design shortcomings, see Wolman Report, 5-7, and Ormond R. Bean, "Notes on the Portland Sewage Disposal Project, May 1933-June 26, 1936," undated typewritten manuscript, folder Willamette and Columbia River Pollution 1933-1934, box 2 Early Sewage Disposal System Data Sewage Systems (1922-1961), group Department of Public Works Bureau of Refuse Disposal (8890-02), SPARC. For a copy of Portland's Public Works Administration application, see City of Portland, Oregon, Department of Public Works, "Application of the City of Portland, Oregon, for a Loan and Grant of $\$ 8,200,000.00$ for the construction of a Comprehensive 
Sewage Disposal System ...," Feb. 1934, box 3 Early Sewage Disposal System Data, Sewer Systems, group Department of Public Works, Bureau of Refuse Disposal (8890-02), SPARC.

${ }^{34}$ See "Attack Launched on River Cities," Morning Oregonian, Dec. 4, 1935, p. 1, and "Pollution Fight Reaches Court," Morning Oregonian, Dec. 6, 1935, p. 1. For details of the fish kill to which these fishermen were reacting, see "Pulp Mill Acid Slaughters Fish," Morning Oregonian, Oct. 19, 1935, pp. 1, 4; "Pulp Mill Denies Polluting Water," Sunday Oregonian, Oct. 20, 1935, p. 6; and "St. Helens Supervisor Bans River Pollution," Morning Oregonian, Oct. 21, 1935, p. 2.

${ }^{35}$ Chapter 350, General Laws of Oregon, 1927, pp. 462-263.

36 "Pestilence from the Sludge Banks," Oregon Daily Journal, Aug. 8, 1936, p. 4.

${ }^{37}$ Frank T. Bell, Commissioner, U.S. Bureau of Fisheries, to Frank B. Wire, Oregon State Game Supervisor, Jan. 9, 1936, p. 1, folder Correspondence re: Water Pollution 1930-1950, box 18, Charlton Papers.

${ }^{38}$ For the scientists and equipment, see Bell to Wire, Jan. 9, 1936.

${ }^{39}$ L. F. Warrick to Charlton, March 28, 1936, folder Correspondence re: Water Pollution 1935-1936, box 18, Charlton Papers. Warrick was a member of Wisconsin's Committee on Water Pollution (CWP), established in 1927; see Summers, Consuming Nature, 19, for more on the CWP.

${ }^{40}$ President Franklin D. Roosevelt created the National Resources Committee (NRC) through Executive Order 7065 on June 7, 1935, under authority of the Emergency Relief Appropriation Act of 1935. The NRC replaced the National Resources Board (NRB). See the full text of Executive Order No. 7065 at http://www.presidency.ucsb.edu/ws/index.php?pid=15075, accessed June 9, 2008.

${ }^{41}$ For more on the work of New Deal natural resource management agencies, see Charles McKinley, Uncle Sam in the Pacific Northwest: Federal Management of Natural Resources in the Columbia River Valley (Berkeley, Calif., University of California Press, 1952); for the Pacific Northwest Regional Planning Council, see particularly pp. 459-467.

${ }^{42}$ The Oregon State Planning Board (OSPB) took over responsibility for this work from the Reconstruction Advisory Board, under the auspices of the federal Reconstruction Finance Corporation, in existence from 1933 to 1935. Before the State Legislature abolished the OSPB in 1939, board authored in excess of forty studies on an array of subjects including governmental administration, economic issues, power generation, wildlife, public works, public lands, and water resources. See "Oregon State Planning Boards Records Guide, Agency History," http://arcweb.sos. state.or.us/state/planbd/hist/planhist.htm, accessed June 10, 2008.

${ }^{43}$ Merryfield, "History, Progress, and Problems," 85.

${ }^{44}$ National Resources Committee Special Advisory Committee on Water Pollution, Report on Water Pollution (Washington, D.C., U.S. Government Printing Office, July 1935; reprint Feb. 1936), 6-8; 60 .

${ }^{45}$ Merryfield, "History, Progress, and Problems," 85; Gleeson, The Return of a River, 19.

${ }^{46}$ Merryfield, "History, Progress, and Problems," 85. Other Advisory Committee members included Portland Mayor Joseph Carson, Jr., Fish Commission Chairman John C. Veatch, State Game Supervisor Frank B. Wire, Crossett Western Company/Crossett-Watzek-Gates Industries executive Aubrey Watzek, Inman-Poulsen Lumber Company Vice President Henry Brooks Van Duzer, Oregon State College Civil Engineering Professor Fred Merryfield, and Oregon Wildlife Federation President Edgar F. Averill. Averill, Wire, Veatch, and Charlton were members of the Oregon Division of the IWLA.

${ }^{47}$ For "cooperative pragmatism," see Terence Kehoe, "The Persistence of Cooperation: Government Regulation of Great Lakes Water Pollution, 1945-1978," Business and Economic History 24:1 (Fall 1995), 147-154, and Kehoe, Cleaning Up the Great Lakes. For the assertion that this approach undermined water pollution abatement efforts in the 1950s and 1960s, see Richard W. Judd, "The Coming of the Clean Waters Acts in Maine, 1941-1961," Environmental History Review 14:3 (Fall 1990), 51-74. 
${ }^{48}$ Christine M. Rosen, "Differing Perceptions of the Value of Pollution Abatement Across Time and Place: Balancing Doctrine in Pollution Nuisance Law, 1840-1906," Law and History Review 11:2 (Fall 1993), 303-381.

${ }^{49}$ For Pennsylvania, see Nicholas Casner, "Angler Activist: Kenneth Reid, the Izaak Walton League, and the Crusade for Federal Water Pollution Control," Pennsylvania History 66:4 (1999), 535-553; for Wisconsin, see Summers, Consuming Nature.

${ }^{50}$ See Stephen Skowronek, Building a New American State: The Expansion of National Administrative Capacities, 1877-1920 (Cambridge, U.K., Cambridge University Press, 1982). For the evolution of regional water management approaches in Oakland and Boston, see Sarah S. Elkind, Bay Cities and Water Politics: The Battle for Resources in Boston and Oakland (Lawrence, Kans., University Press of Kansas, 1998).

${ }^{51}$ Among those most involved in researching legal aspects of the issue was attorney John C. Ronchetto. The Works Progress Administration funded his work for the ACSP beginning in March 1936; see V. B. Stanbery, Consultant, OSPB, to R. E. Koon, Chairman, ACSP, Feb. 25, 1936, folder Oregon State Planning Board 1936, box 20, Charlton Papers. For the final drafts of Ronchetto's work with the ACSP, see Ronchetto, An Analytical Digest of Existing Legislation of Oregon and Other States Relating to Stream Pollution (Salem, Oreg., Oregon State Planning Board Advisory Committee on Stream Purification, Aug. 1936), and Recommended Principles for Stream Purification Legislation in Oregon (Salem, Oreg., Oregon State Planning Board Advisory Committee on Stream Purification, June 1937).

${ }^{52}$ R. E. Koon, Efforts to Reduce Stream Pollution in Oregon (Salem, Oreg., Oregon State Planning Board Advisory Committee on Stream Purification, Feb. 1937), 5-6, in folder Correspondence re: Water Pollution, 1930-1950, box 18, Charlton Papers.

${ }^{53}$ A survey completed in August 1936, for example, found water in Portland's harbor to be devoid of dissolved oxygen during low-water periods; see "Lower Harbor River Water Devoid of All Oxygen," Oregon Daily Journal Aug. 6, 1936, p. 1. For the full report, see Gleeson, A Sanitary Survey of the Willamette River.

${ }^{54}$ Koon, Efforts to Reduce Stream Pollution, introduction, 2. For national context on rivers used as waste sinks, see Joel A. Tarr, The Search for the Ultimate Sink: Urban Pollution in Historical Perspective (Akron, Ohio, University of Akron Press, 1996), and Melosi, The Sanitary City.

${ }^{55}$ Merryfield, A Preliminary Survey of Industrial Pollution, 20-22.

${ }^{56}$ Merryfield, A Preliminary Survey of Industrial Pollution, 3.

${ }^{57}$ Merryfield, "History, Progress, and Problems," 86.

${ }^{58}$ See David Charlton and George Gleeson, "Sewerage Plan Sound Policy," The Spectator, Oct. 27, 1934, pp. 3-4.

${ }^{59}$ In addition to Koon, Efforts to Reduce Stream Pollution in Oregon, and Merryfield, A Preliminary Survey of Industrial Pollution, the other two reports were: Ronchetto, An Analytical Digest of Existing Legislation and Ronchetto, Recommended Principles for Stream Purification Legislation.

${ }^{60}$ This was Senate Bill (S.B.) 414, which Carney substituted for his S.B. 392 on March 3, 1937; S.B. 414 passed both houses on March 8, 1937. See Journals of the Oregon Senate and House, 1937, pp. $245,31,292,300$.

${ }^{61}$ Senator Byron Carney's full biographical information is not known at this time. He was selected to oversee data gathering in Oregon for the 1940 census; see "Byron J. Carney headed for U.S. census birth," Oregonian, Sept. 13, 1939, p. 6.

${ }^{62}$ S.B. 392 , 1937 Legislature, $39^{\text {th }}$ Sess., folder Senate Bills \#390-399, box 28, Item 61-7 Secretary of State 1937 Legislature $39^{\text {th }}$ Session Records, OR State Archives.

63 "Senate Amendments to Senate Bill No. 392," folder Senate Bills \#390-399, box 28, Item 61-7 Secretary of State 1937 Legislature $39^{\text {th }}$ Session Records, OR State Archives. 
${ }^{64}$ S.B. 414,1937 Legislature, $39^{\text {th }}$ Sess., folder Senate Bills \#410-419, box 29 , Item $61-7$ Secretary of State 1937 Legislature $39^{\text {th }}$ Session Records, OR State Archives.

${ }^{65}$ Journals of the Oregon Senate and House, 1937, pp. 245, 31, 292, 300.

66 "It Lost Its Teeth," Oregon Daily Journal, March 13, 1937, p. 4

${ }^{67}$ Governor Charles H. Martin to Honorable Earl Snell, Oregon Secretary of State, March 12, 1937, folder Senate Bills \#410-419, box 29, Item 61-7 Secretary of State 1937 Legislature 39 ${ }^{\text {th }}$ Session Records, OR State Archives. See also "State's Executive Denies Signature to Legislative Acts," Oregonian, March 13, 1937, sec. 1, p. 3.

${ }^{68}$ Oregon Business \& Investors, Inc., Bulletin, 64 (July 28, 1937), 4, in folder 12/4 Legislation, box 12 Stream Purification Records (4/10/4/5), Oregon State Planning Board Records, OR State Archives. The rejected bond issue referred to in this quote was part of failed attempts to secure New Deal public works funding beginning in 1933; see Wolman Report, 5-7, and Bean, "Notes on the Portland Sewage Disposal Project." For arguments for and against this bill, see "Water Bill Held Pulp Plant Peril," Oregonian, March 2, 1937, p. 8; "To Stop Pollution," Oregon Daily Journal, March 5, 1937, p. 12; "Anti-Pollution Bill Protested by Portlanders," Oregonian, March 12, 1937, p. 5; "It Lost Its Teeth," Oregon Daily Journal, March 13, 1937, p. 4; "State Adopts Pollution Bill," Oregonian, March 4, 1937, p. 5.

${ }^{69}$ Oregon Business \& Investors, Inc., Bulletin, 60 (May 24, 1937), 1-2, in folder Oregon State Planning Board-Stream Purification Committee 1936, box 20, Charlton Papers.

70 "Papers Received by Organization," Morning Oregonian, July 22, 1935, p. 15.

71 “Cleaner Streams League Objective," Oregonian, May 9, 1937, p. 17.

${ }^{72}$ Oregon Business \& Investors, Inc., Bulletin, 60, p. 1.

${ }^{73}$ For this dynamic in the state of Connecticut, see John T. Cumbler, "Conflict, Accommodation, and Compromise: Connecticut's Attempt to Control Industrial Wastes in the Progressive Era," Environmental History 5:3 (2000), 314-335.

${ }^{74}$ See, for example, Craig Colten, "Contesting Pollution in Dixie: The Case of Corney Creek," Journal of Southern History 72:3 (Aug. 2006), 605-634.

75 "Cleaner Streams League Objective."

${ }^{76}$ Oregon Business \& Investors, Inc., Bulletin, 60, p. 2.

77 "Would the People Rise?" Oregon Daily Journal, May 11, 1937, p. 12.

78 "Initiative Objective of Stream Group," Oregonian, June 13, 1937, p. 4; see also Oregon Business \& Investors, Inc., Bulletin, 64, p. 2. Other members included Portland City Commissioner Ormand R. Bean and long-time pollution abatement advocates Secretary of the State Board of Health Dr. Frederick Stricker and naturalist William L. Finley.

${ }^{79}$ See Casner, "Angler Activist," 541, 545-546, and Paavola, "Interstate Water Pollution Problems," 450.

${ }^{80}$ Oregon Business \& Investors, Inc., Bulletin, 64, p. 2. Though none of these bills passed, the substance of the Vinson-Barkley bill became part of the 1948 Federal Water Pollution Control Act. For more on this process, see Paavola, "Interstate Water Pollution Problems." The Oregon State Sanitary Authority (OSSA) actively supported many of these bills; see, for example, Oregon State Sanitary Authority Meeting Minutes [hereafter OSSA Minutes] Dec. 15, 1939, vol. 1, pp. 20-21, Oregon State Department of Environmental Quality, Portland, Oreg. [hereafter Oregon DEQ].

81 “Anti-Pollution Petition Work Completed," Oregon Daily Journal, Dec. 16, 1937, p. 3; "League Pushes Better-Stream Movement," Oregon Daily Journal, Dec. 15, 1937, p. 4; "Voters in Oregon are Asked to Decide," Oregon Daily Journal, Dec. 22, 1937, p. 12; "United Against Stream Pollution," Oregonian, March 26, 1938, p. 10; C. C. Chapman, "Pure Streams: Constructive Policies," Oregon Voter, 90:9 (Aug. 28, 1937), pp. 14-15 (pp. 230-231). Chapman called his publication a "Magazine of Citizenship for Busy Men and Women," and though it had a relatively small circulation of 2,500, it 
was influential within the legislature and among municipal leaders. For a more thorough analysis of Chapman and the Oregon Voter, see Barbara J. Henderson, "C. C. Chapman and The Oregon Voter: A Study in Political Influence" (MA thesis, University of Oregon, 1953). The Portland City Club also endorsed this initiative and Portland's sewage funding proposal; see "Stream Pollution Bill Approved," Oregon Daily Journal, Sept. 29, 1938, p. 6.

82 "League Writes Pollution Bill," Oregonian, Sept. 17, 1937, p. 9. See also “Anti-Pollution Bill Being Shaped by Business Firm," Oregon Daily Journal, Aug. 19, 1937, p. 5.

${ }^{83}$ Oregon Business \& Investors, Inc., Bulletin, 64, p. 3.

${ }^{84}$ See "“Clean the Rivers' Committee Formed," Oregon Daily Journal, Sept. 23, 1938, p. 13; Chapman, "Sewage Disposal: Portland Again Asked to Authorize Program," Oregon Voter 95:3 (Oct. 15, 1938), pp. 9-13; and OSSA Minutes June 21, 1940, vol. 1, pp. 51-84.

85 “Complete Anti-Pollution Plan Favored," Oregon Daily Journal, Apr. 29, 1938, p. 28.

86 "Dr. Dillehunt Heads Drive to Put Over Sewage Plan and Clean Polluted River," Oregonian, Aug. 11,1938, p. 8.

87 "Dr. Dillehunt Heads Drive."

${ }^{88}$ Quote from NRC report that Abel Wolman oversaw the research and writing of; see National Resources Committee Special Advisory Committee on Water Pollution, Water Pollution in the United States (Washington, D.C., U.S. Government Printing Office, 1939), 84. For more on Wolman's conservative approach, see Casner, "Angler Activist," 543-544.

89 "Finley Points Out Value of Clean River," Oregon Daily Journal, Oct. 19, 1938, p. 1. \$12 million in 1938 is approximately $\$ 147$ million in 2007, and \$50 million is approximately $\$ 612$ million; Chapman, "Sewage Disposal," and Chapman, "Water Purification," Oregon Voter 95:6 (Nov. 5, 1938), p. 80.

90 "Dirty River Water Kills Fingerlings," Oregon Daily Journal, Oct. 12, 1938, p. 7; see also "Willamette Dip Fatal to Trout," Oregonian, Oct. 13, 1938, p. 1.

91 "River Pollution Seen First Hand," Oregonian, Oct. 11, 1938, p. 5.

92 Joseph Carson, Jr., "Special Message from the Mayor to You, and You," Oregon Daily Journal, Oct. 13, 1938, p. 14.

93 “Germs Indicating Typhoid Discovered in Willamette," Morning Oregonian, Oct. 15, 1938, p. 12.

94 "Portlanders to Hear About Clean Rivers," Oregon Sunday Journal, Oct. 30, 1938, sec. 1, p. 6; "Mayor Puts In 'Hot Licks' for Bill," Oregon Daily Journal, Nov. 5, 1938, p, 12; and "Mayor Carson Dons Deep-Sea Diver's Suit for Personal Investigation of River Filth," Oregonian, Nov. 5, 1938, p. 1.

${ }^{95}$ Gleeson, The Return of a River, 21-22; "Two Bills Strike Blows at Stream Pollution," Oregon Daily Journal, Nov. 10, 1938, p. 16.

${ }^{96}$ Wolman Report, 6.

${ }^{97}$ Brown to Reid, July 22, 1947, p. 2.

${ }^{98}$ Charlton later wrote of this dynamic that "in those days [the late 1930s] the Legislature would not likely have taken this step and that is why [Izaak Walton] League members and others decided to use the Initiative." See Charlton to Felix Streyckmans, Editor, The Izaak Walton League Magazine, Jan. 21, 1962, folder Izaak Walton League 1962 Convention Resolutions, box 8, Charlton Papers. 


\section{ChaPTER 3}

\section{"Being Extremely Practical": \\ The SANitary Authority CONFronts PORTLANd City Officials, 1939 to 1948}

Prior to the creation of the Oregon State Sanitary Authority (OSSA) in 1938, water quality in the state came under the jurisdiction of local health officials if municipal water supplies were the concern or agents of the Oregon Game or Fish commissions if the pollution affected aquatic life. Laws passed in 1911 and 1919 specifically addressed domestic water supplies and vested monitoring and enforcement power at the municipal level. ${ }^{1}$ Administrative reorganizations of the Fish and Game Commissions in 1921 and 1931 empowered commission agents to preserve fish, migratory birds, and the quality of domestic and municipal water supplies. ${ }^{2}$ Advocates established the OSSA in reaction to the failures of Oregon's water pollution laws and Governor Charles H. Martin's veto of Senator Byron Carney's water pollution bill in early 1937 . They also looked to precedents set other states, including Pennsylvania and Wisconsin. ${ }^{3}$

The Oregon State Sanitary Authority and Portland's sewage

The 1938 citizen's initiative creating the OSSA charged the authority with the preservation of the natural purity of state waters. This policy expanded the scope of the state's interest in pollution abatement beyond public health to include recreation and preservation of both aquatic and avian life. In the interest of public welfare, the 
OSSA had the authority to establish regulations, conduct investigations, and hold public hearings. If efforts at securing voluntary compliance for pollution abatement failed, the OSSA could work with the state attorney general to enforce its regulations and decisions. This collaboration could include clarifying state laws, holding citation hearings at which the attorney general would be present, and initiating court proceedings against offenders. ${ }^{4}$

Among the seven OSSA board members at the authority's first meeting on February 25,1939 , were professionals who had long been involved in the Willamette River water pollution issue. These included State Health Officer Dr. Frederick D. Stricker and Chair of the State Fish Commission John C. Veatch. Members elected sanitary engineer Harold Wendel as chair. ${ }^{5}$ Reflecting a pragmatic, cooperative approach, Chairman Wendel succinctly characterized the way the OSSA intended to function: "Being extremely practical," the authority was well aware of the "many problems that exist in the effort of communities to provide sewage disposal facilities" and it would favor any substantive abatement steps. ${ }^{6}$

The OSSA pursued two important goals during its first year: gathering baseline data from industries and municipalities and defining water pollution. Seeking to ascertain "basic information for the intelligent planning of a stream pollution reduction program," members solicited voluntary survey responses from cities and industries. Because individual states were on their own to establish definitions and parameters for what constituted "polluted" water, OSSA members worked on this task as well. ${ }^{7}$ In March 1940, the authority adopted a three-tiered water quality classification system, 
based on the approach the Massachusetts Board of Health's Lawrence Experiment Station, first developed in the 1880s and subsequently applied in many other states. Oregon's system established class A, B, and C streams. Class A streams were to be appropriate for swimming, recreation, sustaining aquatic life, and for use as municipal water supplies, and were not to receive untreated wastes. Class B waters were to be relatively clean but might require a higher level of treatment for domestic use than class $\mathrm{A}$. Class $\mathrm{C}$ waters could receive temporary discharge of untreated wastes if the OSSA determined that such discharges would not preclude other reasonable uses. ${ }^{8}$ Regulations in Pennsylvania also followed the Massachusetts example, but, in contrast to Oregon, Pennsylvania's system gave over one class of streams entirely to municipal and industrial waste discharges. ${ }^{9}$

In the late 1930 s and early 1940 s, the OSSA and other state clean streams advocates faced serious water pollution. The National Resources Council (NRC) produced "the first relatively complete statement of the status of water pollution in the United States" in 1939. This report identified the Willamette and lower Columbia river basins as experiencing a "serious" pollution problem. This rating was on par with the "pollution belt" of the heavily industrialized Northeast and Great Lakes regions and with the California coast from San Francisco to San Diego, impacted by concentrated industrial zones as well as extensive hydraulic mining and petroleum extraction. ${ }^{10}$

Dr. Abel Wolman contributed to the campaign to pass the two water quality initiatives on the November 1938 ballot and was also the lead author of the NRC's 1939 water pollution report. Not long after these projects, Portland city officials 
contracted him to generate a report on the city's sewer needs and costs. The Wolman Report-as it came to be known-was finalized in August 1939 and reflected the best science, knowledge, and technology on sewage treatment in the United States. ${ }^{11}$

The Wolman Report echoed the findings of water quality surveys completed by the Portland City Club (1926), the U.S. Bureau of Fisheries (1926), the U.S. Public Health Service (1929), Charlton Laboratories (1935), the OSC Engineering Experiment Station (1929 and 1936), and others. The Wolman Report characterized the Willamette River as "unsafe for bathing, unsuitable for recreation purposes and impossible for sustained fish and aquatic life," particularly during low flow periods. Sharing the conclusion of Commissioner Bean and other Portland city officials, the report considered the Columbia Slough to be in worse condition than the Willamette and recommended that sewage discharge into the slough cease as soon as possible. ${ }^{12}$ This direct evidence that Portland city officials were acutely aware of the severely polluted Columbia Slough and that officials prioritized this part of the city's sewer upgrade project shows that Portland city officials did not simply sacrifice this part of the city to unmitigated pollution, as asserted in one interpretation of the area's social and environmental history. ${ }^{13}$

The Wolman Report also noted that Portland's proposed sewer project had risen in estimated cost over the course of the 1930 s, from $\$ 6$ million to $\$ 9$ million. However, the authors found that "at no time during this period has a detailed study of the enterprise been accomplished, and that apparently local understanding of the engineering plan and of the methods of financing is not yet completely clarified." 
Such a lack of detailed plans, specifications, and financing methods were primary reasons why Portland officials were not able to secure New Deal infrastructure funding grants in 1933 and 1934, and Wolman found that these shortcomings still plagued the project in spite of successful passage of the 1938 pay-as-you-go financing initiative. $^{14}$

Wolman Report authors held water supply, protection of fish, and recreation as "the highest uses to be protected in a treatment program." The report also identified the proposed Willamette Valley Project as an important part of any overall plan. Without the augmented seasonal flow from the proposed reservoirs, the river was an "unusually sluggish body of water with delayed carrying off of discharged materials" during low-water periods. ${ }^{15}$ The hydrology of the Willamette River system was an important consideration because of the integral role that the "assimilative capacity" of the river itself played in an overall waste disposal strategy. The ability of a given body of water to receive wastes without becoming degraded was a critical aspect of the scientific conservationist approach to waste disposal within broader urban and regional resource management plans. ${ }^{16}$

One of the report's recommendations served as the model for the primary treatment plant and interceptor sewer lines that were eventually completed during the early 1950s. This design consisted of interceptors along both banks of Portland's Willamette River waterfront and an interceptor along the south bank of the Columbia Slough. These large pipes were to direct sewage by way of gravity and pumping stations to a primary treatment facility located in North Portland near Smith Lake. The 
treated effluent was then pumped to an outfall into the Columbia River on the north side of Hayden Island. ${ }^{17}$

Progress on abating Portland's contribution to Willamette River pollution included voter approval of the city's sewer funding proposal in November 1938 and publication of the Wolman Report in August 1939. Immediately after the election, City officials claimed the project was well under way. However, Commissioner William Bowes and Mayor Joseph Carson, Jr. appeared before the OSSA in late 1939 and asserted that insufficient funding precluded the city from taking any further action. ${ }^{18}$ Though the pay-as-you-go funding measure of 1938 authorized a one-third increase in monthly water bills, in the continued Depression the Portland City Council had decided to levy only one-ninth of the monthly water bill increase. ${ }^{19}$

Pollution levels worsened as Portland officials continued to resist developing solutions to finance proposed sewer system upgrades. Not only were salmon and steelhead negatively affected by the degraded state of Willamette River waters by summer 1940, but more pollution-tolerant species such as crawfish and carp were also dying in large numbers. Residents from Salem to Oregon City reported to State Game Warden Edgar F. Averill that it had been necessary "to sweep hordes of dead and dying crawfish" from ferry slips and other surfaces along the river. ${ }^{20}$

William Joy Smith produced a color film in summer 1940 showing the lamentable conditions of the Willamette River. Smith was a member of the Portland Chamber of Commerce, state manager of the National Life Insurance Company, and president of the Oregon Wildlife Federation. His film showed municipal and industrial 
waste discharges from Springfield north to Portland Harbor, providing graphic evidence of the thick, discoloring discharges and mats of detritus in the river from raw sewage outfalls and pulp and paper, meat processing, canning, textile, and other industries. Smith's film also echoed tactics used in the 1938 media campaign in support of water quality initiatives: Men were shown immersing hatchery fingerlings in river water where, in most cases, the fingerlings died within forty-five seconds because of extremely low levels of dissolved oxygen. ${ }^{21}$

Smith produced his film as part of efforts by citizen's groups to convince the City of Portland to commence its proposed sewage disposal project by preparing for post-war sewer construction. Nearly two years after Portland's sewage funding measure had passed, city officials still had not taken any substantive steps. Smith contributed to the efforts of the state Izaak Walton League of America (IWLA) and others increasingly frustrated with this lack of progress. Members of the Sanitary Authority viewed Smith's film at its December 13, 1940, meeting, as the authority continued to pressure Portland officials. ${ }^{22}$

The IWLA's Oregon Division—and some of the division's constituent chapters, particularly the Portland Chapter-responded to the continually deteriorating Willamette River by increasing its involvement in water pollution abatement. Many long-time clean streams advocates spoke at the group's July 1940 annual state meeting. OSSA secretary and state sanitary engineer Carl Green expressed appreciation for federal funding since 1933 that had enabled 44 per cent of Oregon cities to initiate sewage treatment plant construction-save Portland, the city with the 
largest population in the state that continued to dump all of its untreated sewage into the Willamette River and Columbia Slough. William Finley, at that time national IWLA president and vice president of the Oregon Wildlife Federation, critiqued the federal government for leaving too much of the responsibility for water pollution to the states. ${ }^{23}$

Portland officials continued to resist pressure from abatement advocates and the Sanitary Authority well into $1943 .{ }^{24}$ This intransigence, and voter disapproval of a 1943 city measure to levy the full water use service charge, spurred the OSSA to initiate a public campaign in June 1943 to increase pressure on city leaders and educate voters on the need for sewage treatment funding. This campaign was similar to the Oregon Stream Purification League's efforts in 1938 in that it involved editorials, public meetings, and lobbying. However, it did not include the same kinds of fish survival experiments, highly publicized parades, or underwater excursions. The goals of these two campaigns were also distinctly different. In 1938 it seemed that legislation itself would spur progress, but by 1943 the OSSA and other abatement advocates found that this was not the case. Also, the population of the Portland metropolitan area had expanded significantly with the December 1941 entry of the United States in World War II, increasing municipal and industrial waste discharges. As one key indicator of this population growth, employment in the Portland metropolitan area in 1943 was 416 per cent of the 1937 total. $^{25}$

Faced with a growing pollution problem and shortages in funding and staffing, OSSA members realized that the best they could do during the emergency of World 
War II was to push Portland city officials to make adequate progress for post-war sewer projects. ${ }^{26}$ They also wanted Portland officials, representing by far the largest urbanized area in Oregon, to take leadership in such a program. "It might be the salvation of the entire country if we do this," Wendel told city officials, coupling a call for clean streams with the claim that employing servicemen returning from World War II would make a difference in the state's post-war economic health. ${ }^{27}$ Another critic of Portland city leaders, State Senator Lew Wallace, found it ironic that officials devoted funds to build a new highway along the western bank of the Willamette River that would carry tourists within close proximity of a shamefully polluted waterway. ${ }^{28}$

As part of the authority's campaign, OSSA member John Veatch, then State Fish Commission chairman and a member of the Portland Chapter, IWLA, castigated Portland officials in June 1943 for falling behind most upstream communities in the matter of municipal sewage treatment. Veatch noted that communities above Oregon City were progressing on their plans for post-war sewage treatment projects, but Oregon City, Portland, and other lower-river communities were not. Veatch noted that "upstate cities naturally look to Portland for the first decisive moves" on the issue. ${ }^{29}$

From June through October 1943, the OSSA held public meetings and garnered the support of the Oregon Voter, Oregon Journal, and Oregonian, labor unions, the Portland Chamber of Commerce, the Federation of Women's Clubs, and other civic organizations. ${ }^{30}$ In early October, five men who had recently completed a raft journey from Eugene to Portland on a war bond sales campaign spoke at a meeting of Portland clean streams advocates. These men described the "filth" and "slime" they 
encountered on the river "that gave off an odor that was so strong it was offensive a block away." ${ }^{31}$ The authority also wanted Portland's sewage infrastructure needs to be at the forefront of the city's post-war urban plans then being prioritized by leading urban planner Robert Moses of New York and so contacted a representative of Oregon's Post-War Development Commission to this effect. ${ }^{32}$

In spite of these efforts, city officials continued to balk at levying the full water service charge. Portland's East Side Commercial Club, Apartment House Owner's Association, and even former city commissioner J. E. Bennett-who had helped develop the November 1938 sewer funding initiative-joined city officials in lobbying against abatement advocates. ${ }^{33}$ Sanitary Authority members responded that the majority of the Portland city council ignored their repeated requests to increase sewer use charges because of the fear of political consequences stemming in part from a perceived economic burden city officials asserted would fall on individuals and industries and. ${ }^{34}$ These consequences included the possibility that individual commissioners might be voted out of office or that voters would entirely repeal the service charge previously authorized. ${ }^{35}$ The OSSA considered these rationales insufficient and called Portland city officials to an October 1943 citation hearing, the first step in the authority's enforcement process.

The OSSA's October 5, 1943, citation hearing with Portland city officials was in response to more than three years of efforts to urge the city to take active steps to fund sewer interceptors and a primary treatment facility. After their summer campaign, the OSSA had the support of a broad range of Portland business, labor, 
conservation, sportsmen, and women's organizations. ${ }^{36}$ Confronting this coalition and faced with the threat of legal action, in late January 1944 three Portland City Council members-Commissioners Dorothy McCullough Lee, Fred Peterson, and Kenneth Cooper-agreed to craft a measure for Portland voters for the upcoming May election. Their proposal would authorize a $\$ 12$ million bond issue that would replace the 1938 pay-as-you-go system. This funding mechanism followed recommendations of both the 1939 Wolman Report and Robert Moses' 1943 planning report Portland Improvement: ${ }^{37}$ Commissioner Lee called this "the No. 1 project of the Moses report, because before we pretty up our city we should first clean it up."38

Commissioner Bowes continued to lobby against both levying the full water use charge and the $\$ 12$ million bond proposal. In mid-February, Bowes, echoing the arguments of representatives from Portland's Apartment Home Owners Association, opposed the project because of a lack of detailed plans, specifications; and budget. ${ }^{39}$ Though he supported the Moses plan in general, he was wary of moving ahead with funding schemes if the specific details and financial requirements were not known. ${ }^{40}$ In February 1944, the Portland City Council voted to postpone consideration of the Lee, Peterson, and Cooper proposal. In response, on February 21 approximately 200 "representative citizens" organized an "anti-sewage group." ${ }^{, 41}$ Oregon Journal editor Marshall N. Dana chaired this first meeting, and William Joy Smith was selected as a Committee Chairman. ${ }^{42}$ Reacting immediately to this pressure, the Portland City Council voted on February 24 to spend $\$ 200,000$ to develop sewer system engineering plans for post-war implementation and scheduled a vote on 
whether to submit the $\$ 12$ million bond to voters on May $19 .^{43}$ The persistence of the OSSA and the broad-based membership of the Portland Chamber of Commerce's antisewage group spurred this change among Portland City Council members. Worsening Willamette River conditions also contributed.

At a March 1, 1944, City Council meeting, owners and workers of shingle mills along Columbia Slough urged council members to take immediate action because of the "filthy conditions that prevail[led]" on the waterway, "which for years have been a health menace." Impacts of severe pollution from sewage and meat processing firms decreased shingle production by making workers ill and by forming "shoals and bars" of accumulated detritus that interfered with operations. ${ }^{44}$ The next day, the Portland City Council unanimously agreed to submit the $\$ 12$ million sewage disposal bond issue to voters. Although he voted in favor, Commissioner Bowes complained that the cost of the project could only be approximate because detailed plans and specifications had not yet been completed. Other commissioners argued that this action was better than none at all. ${ }^{45}$ Voters approved the measure on May 19 as part of a $\$ 24$ million post-war funding package for schools, roads, docks, and sewers recommended in the Moses Report. ${ }^{46}$

City officials moved swiftly after Portland voters approved funding. In July 1944 they hired A. M. Rawn, General Manager of the Los Angeles County Sanitation District, to conduct a detailed feasibility study following recommendations of the 1939 Wolman Report and the 1943 Moses Report. ${ }^{47}$ Also in summer 1944, Governor Earl Snell approved the recommendation of the Postwar Readjustment and Development 
Commission to provide funding for further comprehensive studies of Willamette River water quality. ${ }^{48}$ In early September 1944 Rawn and Portland city engineers determined the exact forty-acre site for the sewage treatment plant in north Portland and the city began purchasing lots. ${ }^{49}$ As an Oregonian reporter observed, this was the "first definite step taken toward sewage disposal" besides engineering plans and surveys. ${ }^{50}$ By early 1945, some secondary aspects of the project were still being debated, such as the possibility of making a profit by using sewage sludge as an agricultural fertilizer. ${ }^{51}$ However, many residents likely shared the opinion of Oregonian reporter Virgil Smith, expressed in the title of his January 21, 1945, article: "Oregon Waters: Crystal Ball Shows Them Clean Again." 52

Smith lauded the work of the OSSA but also recognized that the long struggle to compel Portland officials to treat municipal wastes involved the concerted efforts of citizen groups. Smith also identified "a new weapon-the need for jobs after the war." Although Willamette River water quality had been deteriorating for decades, clean streams advocates had found it difficult to spur public action in the form of approving funding measures and pressuring city commissioners. As the example of the Willamette River had thus far shown, unless health, recreational, or economic effects were experienced directly, "the actual connection between pollution and values [was] difficult to make." Jobs, however, were "something that every one understands." In surveying the progress of a number of Oregon cities since 1940, Smith concluded that the abundance of planned sewage infrastructure projects showed that "the biggest 
battle has been won. The people, the voters, not only in Portland but elsewhere, have authorized work and consented to being taxed to pay for it." ${ }^{\text {53 }}$

Smith observed that most pulp, paper, vegetable processing, meat packing, flax retting, and other industries along the Willamette had been "inclined to hide behind the skirts of the municipalities in which they operate." For this reason, Smith contended that "it will be much easer to get them in line once the cities do their part." Articulating an economic argument for abating pollution, Smith wrote that the OSSA pursued not only aesthetics and public health but also saw the issue as being "sound business which will bring good financial returns" in commercial fishing and tourism. ${ }^{54}$

Work building Portland's long-awaited sewer project did not begin until July 17,1947 , with a groundbreaking ceremony for the east unit of the Columbia Slough interceptor in the far north of the city. The Oregonian reported that "scores of men and women" involved in the struggle for years watched "with satisfaction and no little emotion" as the ceremonial first earth was removed. OSSA chairman Wendel said that "No longer can they [other Willamette Valley cities] point their finger to Portland as the greatest violator in stream pollution." Commissioner Bowes estimated that the entire project would take approximately three-and-one-half years to complete. Portland Mayor Earl Riley and pollution abatement advocate William Joy Smith also delivered comments. ${ }^{55}$

By late October 1947, OSSA sanitary engineer Curtiss M. Everts was able to report that fifteen Oregon cities, including Portland, had sewage treatment plants under construction or recently completed. Eighty-six Oregon communities were 
considering such plans. ${ }^{56}$ Although the City of Portland and other Willamette Valley communities were finally building sewage treatment systems, pollution of the waterway from industrial pulp and paper manufacturing processes increased. ${ }^{57}$

The OSSA and the pulp \& paper industry

Collectively, the five pulp and paper mills located along the Willamette River and its tributaries discharged hundreds of thousands of gallons per day of waste sulfite liquor and suspended wood fibers. ${ }^{58}$ Without exception, these companies externalized pollution costs by using river and streams as waste sinks, disregarding all other actual and potential uses. However, while it can be useful in some instances to see the pulp and paper industry in Oregon as a monolithic entity, in fact each mill and parent company approached the water pollution abatement issue somewhat differently. These differences stemmed as much from unique corporate and facility cultures to the kinds of production technologies in use, the products produced, the relative profit margins, and the geography of the mill sites themselves. These differences influenced the openness of a given mill or firm to implement abatement practices and systems. From the late 1940s, the Crown Zellerbach mills at West Linn and Lebanon and the Weyerhaeuser mill at Longview, Washington, cooperated appreciably more on the pollution abatement issue in providing regular progress reports and in conducting research on sulfite waste utilization and treatment options. 
Sulfite liquor wastes offered a considerably more complex treatment conundrum compared to municipal wastes. ${ }^{59}$ There were also no federal agencies prepared to offer research assistance and funding to the pulp and paper industry, as the U.S. Public Health Service, U.S. Bureau of Fisheries, and other agencies had been doing for municipalities since the 1910s. For these and other reasons, in 1943 industry executives formed the National Council for Stream Improvement of the Pulp, Paper, and Paperboard Industries, Inc. (NSCI) ${ }^{60}$ Whether or not the NCSI was more than a public relations strategy remains an open question. While some critics charged that this group was little more than a hollow ploy for publicity and an excuse to stall, from the outset, the NCSI funded hydrological and biological research at universities across the nation that would enable the industry to abate measurable pollution while continuing to use streams as waste sinks. ${ }^{61}$

During World War II, OSSA members had focused much of their limited resources on the issue of municipal sewage treatment, particularly in Portland, but did not entirely ignore industrial pollution. The authority held its first meeting focused on industrial pollution in May 1940, as authorized in the 1938 citizen initiative. Pulp and paper officials appeared with representatives from the meat packing, textile, and fruit and vegetable processing industries. Chairman Wendel referenced reports showing that elevated pollution levels were threatening fish life in the Willamette and lower Columbia rivers. Reflecting a common position among industry officials and some sanitary engineers, Cassius Peck of the Crown Zellerbach Company stated that sulfite waste liquors were not harmful to fish life if given adequate dilution. Peck also urged 
the OSSA to keep in mind the relative value of the fishing industry compared to the pulp and paper industry, insinuating that the latter was more economically important and should be given priority. He suggested that the OSSA adopt the Pennsylvania stream classification approach, where some streams were functionally given over to waste. OSSA member Veatch replied that the Willamette could not be given over fully to one classification or another because numerous uses were being made of "that one stream." All industry representatives believed that the OSSA should not do anything to compel them to abate pollution without the cities moving first. ${ }^{62}$

In March 1945, the Crown Zellerbach Corporation was the first pulp and paper company to approach the OSSA with a plan to alleviate the sulfite waste problem. By modifying pulping equipment at its West Linn mill, the facility would be able to evaporate waste effluents to recover valuable chemicals and ignite wood sugars to create energy. Such a system would result in a 70 per cent reduction of pollution discharged into the Willamette, even while the company expanded production. ${ }^{63}$ Crown Zellerbach's project became unfeasible a few months later, however, when the U.S. Army Corps of Engineers announced an upgrade to the Oregon City Locks that was projected to change the water impoundment infrastructure in the immediate vicinity of the West Linn mill. ${ }^{64}$

With the postponement of Crown Zellerbach's plans and a consistent lack of progress from the other four Willamette Valley paper mills, the OSSA called mill representatives to a special meeting in January 1948. The authority heard from representatives that "the industry as a whole and Oregon plants in particular are 
spending large sums in trying to find a solution" to stream pollution. ${ }^{65}$ To make their case, industry officials referenced NCSI research at the University of Washington and Oregon State College on methods to treat or use waste sulfite liquors. The NCSI was also financing work at Rutgers in New Jersey, Syracuse University in New York, and by the Council on the Flambeau River, Wisconsin. Besides trickling filtration, lagooning, and stream aeration, studies also involved producing linoleum cement, artificial vanilla flavor (vanillin), ingredients for insecticides and fungicides, and other products. Most of this work, however, had thus far proven ineffective or economically impractical. ${ }^{66}$

OSSA members and industry representatives engaged in a heated discussion after hearing from industry representatives that there was as yet "no known way of cleaning up sulphite liquor wastes." Chairman Harold Wendel stated that "when the cities have completed these [sewer] building projects and the river is still polluted, the public feeling is very much in favor of having industry clean up their share of the pollution." In summing up what he had heard at this meeting, OSSA member Veatch found all indications pointing toward increased public interest in stream pollution abatement. He advised that the pulp and paper industry understand this fact and start to address the issue in substantive ways. Another OSSA member concluded that the "present status of the program looking toward pollution abatement seems to be that the paper industry has nothing to contribute to solve the problem." 67

\footnotetext{
${ }^{1}$ Chapters 8 and 45, General Laws of Oregon, 1911, pp. 27, 66; Chapters 183 and 264, General Laws of Oregon, 1919, pp. 264-266, 384-437.

${ }^{2}$ Chapters 180 and 310, General Laws of Oregon, 1931, pp. 247-292, 684-728.
} 
${ }^{3}$ Nicholas Casner, "Polluter versus Polluter: The Pennsylvania Railroad and the Manufacturing of Pollution Policies in the 1920s," Journal of Policy History 11:2 (1999), 193-197; Gregory Summers, Consuming Nature: Environmentalism in the Fox River Valley, 1850-1950 (Lawrence, Kans., University Press of Kansas, 2006), 19-30.

${ }^{4}$ Chapter 3, General Laws of Oregon, 1939, pp. 9-14.

${ }^{5}$ Oregon State Sanitary Authority Meeting Minutes [hereafter OSSA Minutes] Feb. 25, 1939, vol. 1, p. 1, Oregon State Department of Environmental Quality, Portland, Oreg. [hereafter Oregon DEQ].

${ }^{6}$ OSSA Minutes Sept. 12, 1941, vol. 1, pp. 129-130.

${ }^{7}$ OSSA Minutes July 7, vol. 1, 1939, p. 9.

${ }^{8}$ OSSA Minutes March 1, 1940, vol. 1, pp. 25-27. For the development of water quality standards generally, see Neil S. Shifrin, "Pollution Management in the Twentieth Century," Journal of Environmental Engineering 131:5 (May 2005), 682-683.

${ }^{9}$ Casner, "Polluter Versus Polluter," 193-194.

${ }^{10}$ National Resources Committee Special Advisory Committee on Water Pollution, Report on Water Pollution in the United States (Washington, D.C., U.S. Government Printing Office, 1939), vi, 39-41.

${ }^{11}$ Board of Review (R. H. Corey, Wellington Donaldson, Carl E. Green, and Abel Wolman), "Report on the Collection and Disposal of Sewage," Portland, Oreg., Aug. 19, 1939 [hereafter Wolman Report], 16-17, 21, in folder 8402-01 Sewage Disposal Project-Sewage Collection and Disposal Report 1939, box 1, Public Works Administration-City Engineer's Historical/Subject Records, City of Portland Stanley Parr Archives and Records Center, Portland, Oreg. [hereafter SPARC].

${ }^{12}$ Wolman Report, 3-4. For Commissioner Beans' opinion of the Columbia Slough, see "Sewage Project Gets Under Way in City," Oregonian, Nov. 11, 1938, p. 3, and "Sewage Plan Ordinance is Prepared," Oregon Daily Journal, Nov. 11, 1938, p. 5.

${ }^{13}$ This finding challenges historian Ellen Stroud's claim of environmental racism. Stroud asserts that "Portlanders in power thought the North Portland Peninsula was a disaster, and so it was"; see Stroud, "Troubled Waters in Ecotopia: Environmental Racism in Portland, Oregon," Radical History Review 74 (1999), 65-95 (quote p. 69). In 1949 the Columbia Slough interceptor was the first section of Portland's sewerage project to be completed; see Ron Moxness, "Progress Report Made on $\$ 16,000,000$ Project," Sunday Oregonian, July 31, 1949, sec. 2, p. 6.

${ }^{14}$ Wolman Report, 4-7.

${ }^{15}$ Wolman Report, 9-10, 14. Other considerations, in descending order of importance to the authors, included the avoidance of extreme odors; economic purposes such as industrial water supply, fish propagation, and preservation of real estate values; and rights of riparian land owners. For more on the context of Columbia and Willamette river development for power, irrigation, and navigation purposes from the late nineteenth century through the 1930s, see William G. Robbins, Landscapes of Promise: The Oregon Story, 1800-1940 (Seattle, Wash., University of Washington Press, 1997), 238295, particularly pp. 283-295 on the Willamette Valley Project.

${ }^{16}$ For an analysis of this practice, see geographer Arn Keeling's study of urban wastewater systems in Vancouver, British Columbia; Keeling, "Urban Waste Sinks as a Natural Resource: The Case of the Fraser River," Urban History Review 34:1. (2005), 58-70.

${ }^{17}$ This is identified as "Project (2)" of the six proposed options; see Wolman Report, 16-17, 21.

${ }^{18}$ OSSA Minutes Dec. 15, 1939, vol. 1, pp. 17-18. The Portland city council authorized a $\$ 5,000$ loan for plans and specifications on November 16, 1938; see "Council Launches Rivers Clean-up," Oregonian, Nov. 17, 1938, p. 6. See also "New Sewage Charge Begins December 1," Oregon Daily Journal, Nov. 10, 1938, p. 34; "Sewage Project Gets Under Way in City," Oregonian, Nov. 11, 1938, p. 3. $\$ 5,000$ in 1938 is approximately $\$ 61,000$ in 2007. 
${ }^{19}$ Sanitary Authority Chairman Harold Wendel stated that Portland was effectively losing $\$ 35,000$ every day that the city council did not authorize levying the full water use charge. See "River Cleanup Plan Stalled," Oregonian, Oct. 5, 1943, sec. 1, p. 10.

20 "Stream Purity Group at Work," Oregon Journal, Aug. 29, 1940, p. 20.

${ }^{21}$ William Joy Smith. Pollution in the Willamette, film (Portland, Oreg., William Joy Smith, Producer, 1940). The Oregon State University Archives identifies this film as "Willamette River Pollution Film, circa 1940." The title is incorrect: Smith called his film "Pollution in the Willamette." The "circa" in the Oregon State University Archives listing reflects previous ambiguity regarding the year Smith made the film. In an oral history from November 1984, long-time OSSA engineer Kenneth Spies responded to a question about the year of the film by stating: "I would guess . . . the summer of [nineteen] thirty-eight or [nineteen] thirty-nine." The Oregon Historical Society listing for Spies' oral history incorrectly dates the film as 1937 . See "Guide to the Willamette River Pollution Film, circa 1940," http://osulibrary.oregonstate.edu/archives/archive/film/documents/OREf059.pdf, accessed Sept. 20, 2008; OSSA Minutes Oct. 5, 1943, vol. 1, p. 265; and Kenneth H. Spies [with David B. Charlton], "A Narration to a 1937 Silent Film about a Boat Trip along the Willamette River," Nov. 1984, oral history recording, Oregon Historical Society, Portland, Oreg. As of November 2008, archivists at the Oregon Historical Society were processing a DVD copy of the film, donated by Mr. Don Yon of the Oregon Department of Environmental Quality. This particular iteration, replicated from a VHS copy, overlays the 1984 Kenneth Spies oral history sound recording onto Smith's silent film. It is unknown when this overlay was made, or by whom. The Oregon State University Archives has made this silent film available for online viewing at http://oregonstate.edu/media/cbnnp, accessed Nov. 23, 2008. At their November 4, 1949 meeting, the OSSA allocated $\$ 900$ to re-print the film and provide a soundtrack; see OSSA Minutes Nov. 4, 1949, vol. 2, p. 217, Oregon DEQ.

${ }^{22}$ OSSA Minutes Dec. 13, 1940, vol. 1, pp. 95-96.

23 "Waltonians Talk River Pollution," Oregon Daily Journal, July 27, 1940, p. 3.

${ }^{24}$ For William Finley's call for Portland City Commissioners to levy the full charge, see "Naturalist on Pollution," Oregonian, Oct. 4, 1943, sec. 1, p. 6.

${ }^{25}$ For more on significant growth in Oregon generally and in the Portland metropolitan area in particular related to war industries, see Carl Abbott, Portland: Planning, Politics, and Growth in a Twentieth-century City (Lincoln, Nebr., University of Nebraska Press, 1983), 125-127 and 136-145, and William G. Robbins, Landscapes of Conflict: The Oregon Story, 1940-2000 (Seattle, Wash., University of Washington Press, 2004), 9-12.

${ }^{26}$ OSSA Minutes Nov. 13, 1942, vol. 1, pp. 227-228. The OSSA was faced with a shortage of qualified sanitary engineers in the fall of 1941, before the United States' entry into World War II, because the U.S. military had already begun enlisting men with this expertise; see OSSA Minutes Sept. 12, 1941, vol. 1, p. 133.

${ }^{27}$ OSSA Minutes Dec. 12, 1941, vol. 1, pp. 137, 141-152.

${ }^{28}$ Lew Wallace, “But We Still Have an 'Open Sewer,"” Oregon Daily Journal, Oct. 7, 1941, p. 12.

29 "City Officials Under Fire for Failure to Clean River," Oregonian, June 5, 1943, p. 9, and "Raft Sitter Tells of Filth," Oregon Daily Journal, Oct. 5, 1943, p. 9.

${ }^{30}$ See "This Time, Let's Do It," Oregonian, July 14, 1943, p. 10, and "Proceedings of Citation Hearing, City of Portland, before the State Sanitary Authority," OSSA Minutes Oct. 5, 1943, vol. 1, pp. 249288.

31 "Raft Sitter Tells of Filth," and "River Cleanup Plan Stalled," Oregonian, Oct. 5, 1943, sec. 1, p. 10.

${ }^{32}$ OSSA Minutes Sept. 17, 1943, vol. 1, pp. 242-245. Robert Moses, Portland Improvement (New

York, William E. Rudge's Sons, Nov. 10, 1943), 13-15, 22, 43.

33 "Proceedings of Citation Hearing," pp. 249-288. 
${ }^{34}$ OSSA Minutes Sept. 17, 1943, vol. 1, pp. 242-244 ; “This Time, Let's Do It," Oregonian, July 14, 1943, p. 10.

${ }^{35}$ OSSA Minutes Dec. 12, 1941, vol. 1, pp. 141-152.

36 "Proceedings of Citation Hearing," pp. 249-288.

37 "Bond Issue for Sewage Plant Urged," Oregonian, Jan. 21, 1944, sec. 1, pp. 1, 10. \$12 million in 1943 is approximately $\$ 120$ million in 2007.

38 "Sewage Group Elects Heads," Oregonian, Feb. 29, 1944, sec. 1, p. 11.

39 "City Council Defers Action on Engineer's Sewer Plans," Oregonian, Feb. 17, 1944, sec. 1, p. 11.

40 "Sewage Disposal Angle Explained," Oregonian, Feb. 11, 1944, sec. 1, p. 5. Historian Carl Abbott finds a strong conservative tendency in Portland city politics in the 1930s and 1940s, particularly in the actions of Commissioner Bowes. Bowes was a staunch supporter of business interests and resisted federal involvement in local affairs; he also advocated for specific, pragmatic planning measures, such as were contained in the Moses plan, while opposing the creation of an independent planning agency in Portland. See Abbott, Portland, 118-119, 141-142.

41 "Representative Portlanders form Anti-Sewage Group," Oregonian, Feb. 22, 1944, sec. 1, pp. 1, 11. Among the group's sponsors and nominating committee were Mrs. C. D. Cummins, President of the Portland Council of Parents and Teachers; Dr. Blair Holcomb, President of the Multnomah County Medical Society; Palmer Hoyt, Publisher of the Oregonian; Louise Palmer Weber, "prominent clubwoman"; and representatives from the Portland Central Labor Council and the Oregon State Industrial Union. Women were prominent among the group's executive committee and elected officers, illustrating an increasingly broad-based membership within the abatement movement. See "Sewage Group Elects Heads," Oregonian, Feb. 29, 1944, sec. 1, p. 11.

${ }^{42}$ Marshall N. Dana served for forty-five years in the news business with both the Oregon Journal and Oregonian and was highly involved in conservation issues, including service as District Chairman of the Pacific Northwest Regional Planning Commission in the 1930s; he was also among the founding members of the Portland Chapter of the IWLA in 1922. For this IWLA connection, see "Izaak Walton League Chapter is Formed Here," Oregon Sunday Journal, Dec. 17, 1922, sec. 2, p. 2.

43 "City Moves to Further Sewer Plan," Oregonian, Feb. 25, 1944, sec. 1, pp. 1, 11.

44 "Shingle Men Tell of Filth." See also Lawrence Barber, Columbia Slough (Portland, Oreg., Columbia Slough Development Corporation, Oct. 1977). Barber created this pamphlet as part of the "Save Our Slough" cleanup efforts in the 1970s.

45 "Bond Issue to be Put on Ballots," Oregonian, March 3, 1944, sec. 1, pp. 1, 7.

${ }^{46}$ Carl Abbott, The Metropolitan Frontier: Cities in the Modern American West (Tucson, Ariz., University of Arizona Press, 1993), 37.

47 "L.A. Engineer Here Advising," Oregonian, July 20, 1944, sec. 1, p. 9. A. M. Rawn was also involved in the redesign of Vancouver, B.C.'s, sewer infrastructure; see Keeling, "Urban Waste Sinks," 62.

${ }^{48}$ These reports included Fred Merryfield, "Stream Pollution Studies-1944: Preliminary Report Submitted to Governor's Special Committee, Oregon State Sanitary Authority," (Corvallis, Oreg., Oregon State Agricultural College Engineering Experiment Station, [Jan.] 1945), R. E. Dimick and Merryfield, The Fishes of the Willamette River System in Relation to Pollution, Bulletin Series, No. 20 (Corvallis, Oreg., Oregon State Agricultural College Engineering Experiment Station, [June] 1945), and Merryfield and W. G. Wilmot, 1945 Progress Report on Pollution of Oregon Streams, Bulletin Series, No. 19 (Corvallis, Oreg., Oregon State Agricultural College Engineering Experiment Station, [June] 1945). For Governor Snell's approval of this funding, see Merryfield and Wilmot, 1945 Progress Report, 7-8.

49 "Bottleneck in Materials Delaying Progress on New City Sewer System," Oregonian, Sept. 19, 1948, sec. 1, p. 28; see also OSSA Minutes vol. 2, Jan. 23, 1948, 82-86. 
50 "Sewer Plant Site Chosen," Oregonian, Sept. 7, 1944, sec. 1, p. 6.

${ }^{51}$ On the production of sewage treatment by-products, as late as March 1945 consulting engineer A. M. Rawn suggested that up to $300,000 \mathrm{ft}^{3}$ of gas could be produced per day and used to generate electricity if cheap hydroelectricity was not already available and that profit might also be made from sewage sludge used for agricultural fertilizer, but only if the sludge could be dried without cost, as was possible in sunny Los Angeles. See "Sewage Plans Revised to Fit," Oregonian, March 27, 1945, p. 5. For analyses of attempts to use sewage treatment byproducts in the United States, United Kingdom, and France in the nineteenth and twentieth centuries, see Joel A. Tarr, "From City to Farm: Urban Wastes and the American Farmer," Agricultural History 49:4 (Oct. 1975), 598-612; Nicholas Goddard, “'A Mine of Wealth'? The Victorians and the Agricultural Value of Sewage," Journal of Historical Geography 22:3 (1996), 274-290; John Sheail, "Town Wastes, Agricultural Sustainability, and Victorian Sewage," Urban History 23:2 (Aug. 1996), 189-210; and Sabine Barles and Laurence Lestel, "The Nitrogen Question: Urbanization, Industrialization, and Water Quality in Paris, 18301939," Journal of Urban History 33:5 (July 2007), 794-812.

${ }^{52}$ Virgil Smith, “Oregon Waters: Crystal Ball Shows Them Clean Again," Oregonian, Jan. 21, 1945, magazine section, p. 5. For an expression of other questions about the project, see "Sewage Plant Opinion Asked," Oregonian, Oct. 26, 1944, sec. 2, p. 3.

${ }^{53}$ Smith, "Oregon Waters."

${ }^{54}$ Smith, "Oregon Waters." See also Robbins, Landscapes of Conflict, 250-251.

55 "Works Begins on Sewage Disposal System Authorized by Portland Voters in 1944," Oregonian, July 18, 1947, p. 14.

56 "Oregon Cities Push Work on Sewage, 15 Disposal Plants Under Construction," Oregonian, Oct. 26, 1947, p. 20; OSSA Minutes July 11, 1947, vol. 2, pp. 60-65.

${ }^{57}$ In late October 1947, fifteen sewage treatment plants were under construction in communities along the Willamette River; see "Oregon Cities Push Work on Sewage."

${ }^{58}$ George W. Gleeson and Fred Merryfield, Industrial and Domestic Wastes of the Willamette Valley, Bulletin Series, No. 7 (parts 1, 2, and 3) (Corvallis, Oreg., Oregon State Agricultural College Engineering Experiment Station, [May] 1936).

${ }^{59}$ August S. Erspamer and William D. Rice, "Treatment of Pulp and Paper Mill Waste," Industrial and Engineering Chemistry 41:8 (Aug. 1949), 1806.

60 "The National Council for Stream Improvement," Science 99:2582 (June 23, 1944), 508.

${ }^{61}$ The NCSI is currently known as the National Council for Air and Stream Improvement (NCASI). See "About Us," http://www.ncasi.org/about/default.aspx, and University of Michigan School of Public Health, "History of Environmental Health Sciences," http://www.sph.umich.edu/ehs/history.html, both accessed Sept. 30, 2008. For summaries of research funded by the NCSI in the 1940s and 1950s, see Isaiah Gellman, "Support of Water Pollution Research Projects at Research Institutions by the National Council for Stream Improvement and Other Industrial Associations," in Edward F. Eldridge, ed., Proceedings of the Second Pacific Northwest Symposium on Water Pollution Research:

Financing Water Pollution Research Projects, Jan. 20, 1958 (Portland, Oreg., U.S. Department of Health, Education, \& Welfare, Public Health Service, Region 9, 1958), 7-11.

${ }^{62}$ OSSA Minutes May 7, 1940, vol. 1, pp. 32-33 and 38-50.

${ }^{63}$ OSSA Minutes March 9, 1945, vol. 2, pp. 10-11.

${ }^{64}$ OSSA Minutes June 22, 1945, vol. 2, pp. 14-15.

65 "Report asked on Sewage," Oregonian, Jan. 24, 1948, p. 7; see also OSSA Minutes Jan. 23, 1948, vol. 2, pp. 86-107.

${ }^{66}$ OSSA Minutes Jan. 23, 1948, vol. 2, pp. 86-107.

${ }^{67}$ OSSA Minutes Jan. 23, 1948, vol. 2, pp. 86-107. 


\section{Chapter 4}

\section{“Cleaner But Not Clean”:}

\section{THE Limited SuCCESSES OF ABATEMENT AdvocATES, 1948-1962}

Citizen groups and state agencies focused their pollution abatement efforts since at least the mid-1920s on finding solutions to municipal sewage. This focus predominated through most of the 1940s as well, notwithstanding the Columbia River fisher's suit against industrial concerns in the mid-1930s and the periodic focus on industrial pollution at Sanitary Authority meetings since 1939. State and municipal officials, Sanitary Authority staff, and pollution abatement advocates perceived the commencement of Portland's sewage treatment project in July 1947 as an important victory. Only a few months later, the Oregonian discerned a shift in the focus of pollution abatement advocates beyond the issue of municipal wastes to include also industrial uses of the river. Finding this issue to be complex, the Oregonian concluded that industry should not be curtailed, "but merely that the public rights to rivers be maintained, as now they are not."

The federal government was becoming more involved in water pollution abatement during the same period in which the issue in Oregon was shifting from a focus on Portland's sewage to an increasing awareness of the deleterious effects of pulp and paper industry wastes. Reformers nationwide succeeded in passing the first comprehensive federal water pollution legislation in June 1948, when Congress passed the Water Pollution Control Act (Public Law 845). In a letter to Minnesota Representative John A. Blatnik supporting this bill, David Charlton wrote that "there 
is a growing demand by citizens and various organized groups that increasing pollution of our streams be stopped and that present pollution reduced to the minimum and kept under effective control by federal legislation, if the states are unable or unwilling to do so."2

The Federal Water Pollution Control Act was the first comprehensive federal legislation addressing water quality. The National Resources Committee and U.S. Senators and Representatives had proposed core aspects of this legislation in the 1930s, but U.S. participation in World War II took attention away from a national water pollution management approach. ${ }^{3}$ The 1948 legislation established a similar relationship between the states and the federal government that the creation of the OSSA established between the state and Oregon municipalities. The act increased federal technical and financial assistance to cities and states, and Congress gave the U.S. Public Health Service (USPHS) some enforcement authority largely limited to interstate waters and issues of public health. By constraining the federal government's ability to enforce water quality regulations in these ways, however, Congress made sure not to impinge upon a state's right to administer and enforce water quality management programs. ${ }^{4}$ This dynamic of conflict between state's rights and federal water quality regulations was apparent since at least the 1930s during debates on the Vinson-Barkley bill and related federal legislative proposals.

Legislators were reacting to important changes across the United States during and immediately after World War II when they passed Public Law 845. With federal investment in critical war industries throughout the West, by the late 1940s many 
metropolitan areas and their hinterlands were poised to take advantage of an increased population and greatly expanded transportation and communication infrastructures to grow in national and even international importance. ${ }^{5}$

Portland and its suburbs, including Vancouver, Washington, had gained 250,000 residents as part of war-related employment opportunities. ${ }^{6}$ Oregon's population continued to expand significantly after World War II. During the 19471948 biennium, Oregon was first among the forty-eight states in population growth by percentage gain at 49.3 percent. $^{7}$ This accelerated growth and development continued to be particularly apparent in Portland and within the entire Willamette Valley: in 1950, Portland contained 373,628 and Multnomah County 471,537 residents, and the next three most populous cities and counties were all within the Willamette River watershed. Overall, between 1940 and 1950, the city of Portland grew by 23.3 per cent, and Multnomah County grew by 32.8 per cent. Increased population and industrial expansion taxed every aspect of the region's infrastructure, further degrading the Willamette River, lower Columbia River, and Columbia Slough. ${ }^{8}$

The Oregon State Sanitary Authority and the Willamette Valley pulp \& paper industry

Some observers at the end of 1948 may have concluded that the state was making progress abating water pollution, even with the effects of rapid growth and industrialization. Portland had finally begun construction of a comprehensive sewer system upgrade and increasingly more cities in the Willamette Valley were building 
their own primary sewage treatment systems. Even the most significant polluters, the pulp and paper industry, had been put on notice to take proactive abatement steps or face legal measures as provided for in the Sanitary Authority's 1938 enabling legislation.

Skeptical that cities, industries, or even the OSSA were truly making progress, in September 1948 David Charlton wrote to Clarence W. Klassen, a nationally respected sanitation engineer and head of the Illinois Sanitary Water Board, that "our streams are more polluted than they ever were, though there are plans and some construction with respect to municipal wastes." Charlton drew specific reference to the pulp and paper industry's National Council on Stream Improvement: "Our pulp and paper mills have done nothing so far," he wrote, "except contribute to their industrysponsored research program." As the latest report from industry representatives in January 1948 had concluded, this research program had thus far failed to produce any substantive abatement practices or technologies, much to Charlton's dismay. ${ }^{9}$

Charlton also tracked efforts to abate industrial pollution along the Fox River in Wisconsin, where the state's Izaak Walton League of America (IWLA) members had been lobbying for changes in pulp and paper waste discharge practices since the 1920s. ${ }^{10}$ Wisconsin's IWLA President V. J. Meunch wrote Charlton in December 1949 to note how closely the situation in Oregon paralleled that of Wisconsin. ${ }^{11}$ Continued correspondence between Charlton and Meunch on this matter helped convince national IWLA leadership to establish the organization's first permanent 
industrial pollution abatement committee in late 1949 , focused at first on sulfite wastes. Charlton was one member of this committee. ${ }^{12}$

By the late 1940s, Charlton had expanded his involvement in local and state activities of the Izaak Walton League to serve as an active member of the national organization. The relationships he fostered in this capacity provided the technical and scientific evidence he used to supplement—and at times contradict-research that industry representatives cited. His contacts also provided examples of other cities and states attempting to develop administrative and policy solutions. ${ }^{13}$ Charlton held a consistent moral opposition to water pollution, but he was also a careful scientist and trained professional, as the thoroughness of his research showed.

While pressing for pollution abatement, Charlton and most other advocates in Oregon did not call for the river to be pure. They understood that some level of pollution was to be expected in a modern industrialized society. ${ }^{14}$ Waltonians in particular argued for a "common sense medium" between the extremes of "asthetic [sic] theorists preaching conservation for conservation's sake" and sportsmen interested only in "taking more and bigger fish."15 Charlton wrote that "“The Beautiful Willamette' of poetry may not return in our present era of civilization," but with the continued push of clean streams advocates, the river would "look better, smell better, support fish life and be less offensive." ${ }^{16}$ With these goals in mind, the Oregon IWLA produced a report in December 1948 that accused Willamette Valley pulp and paper mills of stalling. Charlton, as committee chair, made use of his own research to contradict claims that sulfite liquor treatment technologies were not available. In this 
report Oregon Waltonians also called for "changes in the authority's personnel and operating practices or its outright abolishment." 17

Charlton had attended his first OSSA meeting just a few months prior to publication of the Oregon IWLA's report. He registered the division's dissatisfaction with the lack of progress by the pulp and paper industry and reminded authority members that industry officials expressed as early as 1937 that they would be willing to try feasible abatement methods. Charlton insinuated that both this and current industry claims were stalling tactics. Based on his own research, he asserted that mills were not making as much progress as their publicity indicated, particularly as the industry's National Council for Stream Improvement (NCSI) asserted. ${ }^{18}$

The Oregon Division's report on water pollution found that "the Willamette River is more grossly polluted than ever, chiefly from pulp and paper mills and food processing plants," ten years after passage of the 1938 citizen initiative creating the OSSA. The report critiqued pulp industry representatives who asserted there were no economical methods to treat or dispose of waste sulfite liquors by referencing two specific methods. One was producing alcohol by fermenting wood sugars. The other involved an alternate pulping process being tested at the Weyerhaeuser plant in Longview, Washington. This process substituted magnesium oxide for calcium bisulfate as a pulping base, from which solids were more readily evaporated for burning (and generating electricity) and a higher percentage of chemicals recycled. Industry officials implied that Willamette Valley pulp mills would adopt this technology if it was proven successful. ${ }^{19}$ 
In reply to these examples, OSSA Chairman Wendel asserted that such methods were not the panacea that the IWLA imagined. If all mills started producing alcohol, Wendel argued, much more would be produced than could be sold, which would drive down prices and make further production unprofitable. Regarding the alternate pulp making process, Weyerhaeuser officials were still far from knowing definitively whether or not it would be both effective and economically feasible. ${ }^{20}$

Notwithstanding such arguments about appropriate technologies and economic feasibility, there was some validity to Charlton's claim that the industry was not making appreciable progress. In fact, industry may have been avoiding the issue of pollution abatement altogether. At their December 1948 meeting, Sanitary Authority secretary Carl Green reported on effluent data requested from the five Willamette Valley mills. After repeated requests since the early 1940s, either the mills had yet to measure the amount and strength of their own effluents or they chose not to report this information. ${ }^{21}$ In spite of industry's claims to the contrary and their repeated references to NCSI-funded research, they had failed to comply with the straightforward task of reporting effluent quantities and strengths. This suggests that Charlton and others were correct in claiming the industry was stalling.

Reacting to increased criticism as well as pulp and paper industry intransigence, the authority invited public participation at its February 1949 meeting. Even though the OSSA's quarterly meetings had always been open to the public, Chairman Wendel observed that "very few persons have ever attended." Wendel wanted to dispel rumors that the authority "concealed facts" and was confident that 
public observation of the Authority's work would convince skeptics that stream pollution was complex and "cannot be corrected without public co-operation and support., 22

Conservationists, industry representatives, and state and federal agency officials were among the attendees at the February 1949 Sanitary Authority meeting. They heard about the progress of experiments with the alternate process at Weyerhaeuser's Longview mill and on research in Wisconsin. Experiments in Wisconsin had thus far shown that holding waste liquors in large lagoons often led to water contamination, and that reducing the wastes' biological oxygen demand (BOD) using trickling filtration technology was prohibitively expensive. The most costeffective methods for dealing with sulfite wastes in Wisconsin appeared to be using these wastes as a road binder or growing yeast for cattle fodder. As the meeting concluded, a representative of the Portland Chamber of Commerce was convinced that industrial pollution abatement was "being handled in an intelligent manner by the Authority," faced as it was with a lack of adequate technologies to treat or use sulfite wastes. $^{23}$

A few months later, authority members agreed that most Oregon municipalities were making adequate progress in abating municipal waste issues. The OSSA foresaw 1952, the year that Portland sewer project was to be completed, as the year that most of the state's sewage pollution issue would be solved. ${ }^{24}$ Pollution from pulp and paper mill effluent was still a growing problem, however. 
In spring 1949 , sanitary engineers found that each of the five Willamette Valley pulp and paper mills discharged the equivalent pollution load of a city of 400,000 to 500,000 residents, as measured by $\mathrm{BOD} .{ }^{25}$ Combined, these discharges equated to a population equivalent of $2,851,000$, or 90 to 95 per cent of the river's total pollution load. ${ }^{26}$ For comparison, the combined BOD from all other industries above Portland was 450,000 , and the sewage population equivalent for communities above Portland was $203,750 .{ }^{27}$ In actual population numbers, in 1950 Portland numbered 373,628 and Multnomah County 471,538 residents. ${ }^{28}$ Put another way, the five Willamette Valley mills discharged between twenty and thirty million gallons of effluent into the river per day, whereas a typical primary sewage treatment plant serving a population of 50,000 residents discharged ten million gallons per day. ${ }^{29}$ As these figures show, the pulp and paper industry was by far the largest point-source polluter in the Willamette Valley by the late 1940s, as it had been since at least the 1930s.

The OSSA tried to work cooperatively with the pulp and paper industry, understanding that abatement solutions were lacking. Authority members remained open to proactive solutions, however temporary. ${ }^{30}$ Nevertheless, pulp and paper firms had not yet been able to develop an economical way to use their sulfite wastes and used this fact to assert that they could not abate their pollution. Clean streams advocates in Oregon were not alone in hearing such arguments from industry representatives: as historian John T. Cumbler concludes, "the search for a scientific and technological transcendence could easily become a slippery slope to acceptance of 
environmental loss until a solution appeared. ${ }^{, 31}$ Such arguments stalled pollution abatement efforts along the Willamette River and throughout the United States.

In July 1949, Sanitary Authority members concurred that the mills would not make any real progress unless forced. Armed with data from their 1949 survey, the authority exercised its enforcement powers as specified in the 1938 citizen's initiative and gave the five Willamette Valley pulp and paper mills until December 31, 1951, to cease polluting the river or shut down. They set their compliance date to coincide with the expected completion of Portland's sewer interceptors and treatment plant. Chairman Wendel foresaw that "as the Portland sewerage system was completed, the public would be very much concerned if private industry continued to pollute the waters of the state." ${ }^{32}$ Showing that pulp and paper industry incompliance was not limited to Oregon, the Washington Pollution Control Commission had recently issued its own ultimatum to mills in the Everett area, ordering abatement by September $1951{ }^{33}$ Such actions illustrate the evolution of water quality management policies in the mid-twentieth century United States, particularly the limited feasibility of the cooperative pragmatic approach when industries and state agencies differed on what constituted "cooperation." 34

Both municipal and industrial water pollution were complex economic, technological, and regulatory conundrums, as the examples of Portland's sewer system and sulfite waste liquors had thus far shown. Clean streams advocates had been motivated by considerations of economics, recreation, and morals, and sought to apply technical expertise and scientific evidence to support their position. ${ }^{35}$ Undergirding all 
water pollution abatement approaches were quantifiable impacts on the environment that were increasing in the immediate post-war era.

The Oregon Journal presented readers in mid-September 1949 with a disturbing photograph showing the severe negative effects of water pollution. In this image, thousands of crawfish climbed over their dead and dying species mates in a futile attempt to get out of the heavily polluted Willamette River waters near Scappoose, approximately twenty miles downriver from Portland. In addition to dying crawfish, trout, and salmon, "hardy bullhead" were also expiring in large numbers throughout the lower Willamette and its tributaries. Biologists called this particular die-off the worse they had yet seen. Long-time ferry pilot George McCartney from Sauvie Island, approximately twenty-one miles downriver of Portland, first noticed large-scale crawfish deaths in about 1942 , but the $1949^{\circ}$ event was the largest yet. $\mathrm{He}$ predicted the crawfish would disappear, "just like the catfish and crappies went." ${ }^{36}$

Shortly thereafter, representatives from the pulp and paper industry and David Charlton addressed the Multnomah Anglers and Hunters Club about progress in industrial water pollution abatement. A Crown Zellerbach official said that it was false to assert that the industry was not making progress and referenced the hundreds of thousands of dollars the industry had contributed to their stream improvement council. Charlton countered this by claiming that "research frequently is used as a delaying mechanism." Echoing his stance in the Oregon IWLA's 1948 report, Charlton also bemoaned what he perceived as a lack of leadership on the part of the OSSA and other state officials, and found that, by default, leadership had been left to sportsmen's 
groups. ${ }^{37}$ Another of Charlton's critiques was that "news accounts and even biennial reports from the Authority often stressed progress made without putting equal emphasis on the lack of progress, thus the public might get a false impression that all is well." 38

In November 1949, pulp and paper industry officials asked the Sanitary Authority to postpone its December 31,1951, abatement deadline by up to five years. Chairman Wendel reminded these officials that it was the duty of the OSSA to carry out the will of the people, and this meant continuing the call for industry to abate its pollution in a timely manner. When industry officials then requested research assistance, Chairman Wendel explained that "it was not the duty of the Authority to solve the financial problems of industry or to conduct their research for them." Officials from the Publishers' Pulp \& Paper Company responded by lodging a formal objection to the OSSA's stance and made plans to file an appeal with the state attorney general. The core of their complaint was that pollution abatement was an undue economic burden. OSSA member B. A. McPhillips drew attention to the many municipalities that the Authority had pushed into building sewer treatment works even though to do so was a financial difficulty. "Are we to understand," McPhillips queried, that the Publishers' Paper Company is asking the Authority to desist from trying to enforce the pollution law, in spite of the fact that all municipalities representing the greater portion of the people of the state of Oregon are being forced to comply, and that other industries also are being required to abate pollution?

Publishers' attorney countered that an important difference was that there was a solution for sewage but not for sulfite wastes. In reply, OSSA members expressed 
hope that the intervening two-and-one-half years before the deadline would be sufficient time for the industry to develop solutions. ${ }^{39}$

The Oregonian applauded the OSSA's toughening stance. The newspaper recognized that industry faced a complex issue, but referenced increasing public concern that industry used arguments about complexity and economic costs to delay action. ${ }^{40}$ Supporting this position, the Oregon Journal agreed that forcing industries to comply would "be a form of expiation by our civilization for some of its sins against nature. ${ }^{, 41}$ These and other editorials supporting enhanced abatement measures for both cities and industries echoed the position of the Oregon IWLA and other advocates. ${ }^{42}$

The industrial pollution issue continued to escalate, however. The OSSA's February 1950 meeting provided a venue for pulp and paper industry representatives to give testimony to Oregon Attorney General George Neuner. ${ }^{43}$ With this information, Neuner and the OSSA would make a determination about whether or not to bring charges against these firms, as authorized in Oregon's 1938 Water Purification and Prevention of Pollution Bill.

Crown Zellerbach officials felt compelled immediately following this meeting to clarify statements a company representative had made. In spite of what the OSSA recorded in its minutes, a company representative said that it was not threatening to close its mill at West Linn if the authority maintained its strict deadline. The company official claimed that the company was "zealously attempting to solve the many problems involved in sulphite waste disposal." However, if the company had not developed an abatement system by December 31, 1951, and if the authority was not 
willing to compromise on this deadline, then the company "would have no alternative but to obey the order of the lawful authority" and close its mill. "Any closure," therefore, "would result only from Crown's inability to comply with orders made by lawful authority." 44

With this statement, Crown Zellerbach officials were responding to the tide of public sentiment that was becoming less tolerant of the Willamette River's continued use as a waste sink. ${ }^{45}$ These officials were also trying to draw a nuanced distinction while laying the blame for possible future mill closures on the OSSA and Oregon laws. Chairman Wendel and other authority members had long recognized that there were no simple solutions to treating or reusing sulfite wastes, but they had asserted since 1939 that they would be open to any plausible abatement option. Rather than respond even to the Authority's requests to provide basic data on their effluents, pulp and paper industry officials had instead consistently avoided action, requested extensions, and deferred to their research group.

In response, Attorney General Neuner prepared a finding of fact that summarized the most recent OSSA water quality data and made a determination on the contentious deadline. As of early 1950, the Willamette River below Salem and the Santiam River below Lebanon were both devoid of sufficient dissolved oxygen (DO) during the low-flow months of July through October. Although the five Willamette Valley mills contributed 90 to 95 per cent of oxygen-depleting discharges, these mills were not implementing any known abatement options, such as lagooning sulfite liquors for release during high-water periods. ${ }^{46}$ Approximately 50 per cent of 
municipalities along the Willamette River had built primary sewage treatment facilities but, with the continued discharge of pulp mill effluent, this would not be enough to elevate DO levels in the Willamette River sufficient to support fish. Therefore, the attorney general found that pulp and paper industry pollution violated Oregon laws and OSSA edicts and ordered the mills to cease discharging effluents from July 1 to October 31 and at any other low-water period. Neuner warned industry officials that they could not rely on the completion of the thirteen-dam Willamette Valley Project as a partial remedy, although releases from reservoirs would increase water flow in the summer and fall. Within these limitations, he extended to May 1, 1952 , the compliance date for firms to submit plans, a pragmatic approach reflecting the difficulties involved in developing abatement technologies and the importance of the industry to the state's economy. ${ }^{47}$

In late September 1950, another large-scale fish kill occurred in Portland Harbor. Sanitary Authority engineer Kenneth Spies was surprised that the dead fish he saw along the banks had been able to make it that far. He noted that recent OSSA tests had shown "hardly any oxygen left in solution in the Willamette from Cottage Grove through Portland to the Columbia," an annual occurrence during the low-flow months. $^{48}$

Two research efforts in 1950 echoed Spies' findings. The pulp and paper industry's stream improvement council published its own survey and found the river above Oregon City in worse condition than at any time in the past, as gauged by DO content. ${ }^{49} \mathrm{~A}$ few months later, President Truman's National Water Pollution Control 
Advisory Board visited Portland during its tour of the nation's ten major river basins. ${ }^{50}$ After hearing comments on abatement progress from regional industry representatives, board members found the region to be "behind the times" relative to other areas of the country in terms of state administration of the water quality issue and industry compliance with and implementation of abatement measures. ${ }^{51}$

In spite of pulp and paper industry threats and continued seasonal die-offs of Willamette River aquatic life, by the middle of 1951 state officials perceived progress toward sulfite waste abatement. In June, the OSSA and the Oregon Health Board complimented the pulp and paper industry for finally building waste storage lagoons. The Crown Zellerbach and Publishers' companies had been conducting research on this practice in partnership with engineers at the Oregon State College Engineering Experiment Station since November 1950. Construction of other lagoons at Crown Zellerbach's West Linn mill, Spaulding's Newberg mill, and Oregon Pulp \& Paper's Salem mill continued throughout $1952 .{ }^{52}$ State officials expressed guarded confidence that the potential of these lagoons meant that the river would be free of waste liquors during the low-flow months as early as $1952 . .^{53}$

Publishers' Pulp \& Paper Company officials were involved in two other abatement projects. Staff at Clackamas County and the Publishers' mill at Oregon City collaborated on experiments in summer 1951 to use sulfite wastes as binder for gravel roads. These trials followed successful experiments in Washington, Wisconsin, New Jersey, Maine, and Scandinavian countries. Clackamas County officials found the practice more cost effective than using waste oil, but the solution would not be 
appropriate for communities incurring the costs of shipping the wastes farther from the center of production. ${ }^{54}$ As experiments continued, however, Publishers' officials soon realized that Clackamas County would not be able to use a sufficient volume of their waste liquors. To address this issue, Publishers' gained approval from the OSSA in early 1953 to barge wastes in 120,000 gallon batches to be dumped in the Columbia River during the Willamette's low-flow period. ${ }^{55}$ In late July 1953, Publishers' launched their first barge from Oregon City and released it "harmlessly" into the Columbia. ${ }^{56}$

Given some limitations, the OSSA found positive initial results from lagooning experiments and using waste sulfite liquors as a road binder. ${ }^{57}$ At the very least, these methods meant that waste discharges into the Willamette River decreased during periods of low water flows. ${ }^{58}$

Echoing the complexity of the issue, editors at the Oregonian expressed contradictory opinions on the progress of abating Willamette River pollution. Early in 1952, the Oregonian found abatement efforts to be "a slow and discouraging fight, in which the state authorities seem to have fallen behind public opinion." ${ }^{59}$ However, a few months later the Oregonian congratulated state residents and foresaw that water pollution was nearing an end. Influencing this positive interpretation was the soon-tobe-completed Portland sewer system and an "increasingly health attitude of pulp and paper companies along the Willamette" that illustrated "the wisdom of authority policy. ${ }^{, 60}$ During the 1950 s, however, solutions state and federal agencies pursued did not keep pace with environmental pressures put on the Willamette River watershed by 
an expanding population, increasing industrialization, and the growing impact of other forms of pollution.

Slime in the Columbia, blood in the slough, and not enough water to go around

By the end of 1953, some discernable changes in industrial and municipal waste disposal practices were apparent. Pulp and paper mills were lagooning wastes, using them as a road binder, or barging them to the Columbia River. In addition, contractors had finished Portland's sewer interceptor and treatment facility in late October, joining the more than 50 per cent of other communities along the river with sewage treatment systems. Pressure from Oregon Waltonians and Sanitary Authority members spurred these changes, aided by undeniable evidence of environmental degradation. As the 1950s progressed, however, the water pollution issue became increasingly more complex, undermining previous achievements. Illustrating this complexity are the cases of the Sphaerotilus ("slime") pollution of the lower Columbia River, wastes from meat processing plants along Columbia Slough, and the integral role played by Willamette Valley Project reservoirs in abatement practice and policy.

The Columbia River slime problem had intensified since the first report on the topic in 1943. This research found that the slime that coated fisherman's nets and suffocated juvenile fish was a strain of Sphaerotilus, "a filamentous, sheath-forming fungus." The fungus peaked in the warmer water temperatures of summer and early fall and fed on carbohydrates found in sulfite waste liquors as well as on phosphorous 
and nitrogen, particularly in concentrations of $50 \mathrm{ppm}$ or greater. ${ }^{61}$ Not surprisingly, fishers and pulp and paper mill representatives held different opinions regarding the cause of the slime. The former asserted that the problem was directly related to sulfite waste liquors, while the latter claimed that there was "little harm from the liquor for animal life." Wastes from mills on the Willamette and lower Columbia rivers may have had "a cleansing effect upon the river," these industry representatives opined. ${ }^{62}$

The Oregon and Washington state water pollution authorities had been meeting every six months since 1948 to address lower Columbia River pollution. Based on their 1943 report and a U.S. Fish and Wildlife Service survey in 1948, they developed a plan to dilute sulfite wastes to concentrations of less than $50 \mathrm{ppm} .{ }^{63}$ In 1950 the Oregonian observed increased collaboration among state and federal officials and industry representatives and claimed that "a new era" was dawning. ${ }^{64}$ However, the slime problem only intensified. The construction of dams, more industrial development in the region, and increased water diverted for agricultural purposes had drastically changed the character of the Columbia River. By 1953, ten years after their initial report, Oregon's and Washington's water quality authorities found that diluting wastes to $50 \mathrm{ppm}$ still led to increased concentrations of materials that spurred slime growth. ${ }^{65}$

On September 10 and 11, 1958, representatives from Oregon's Sanitary Authority, Washington's Pollution Control Commission, industries, and other groups met at a U. S. Public Health Service symposium in Portland to discuss the Columbia River slime problem. The USPHS sponsored at least eleven of these regional research 
symposia about every six months between 1957 and 1963. Conferees in September 1958 focused on the two principal types of pollution on the lower Columbia: bacteria found in insufficiently treated sewage and slime from pulp and paper mill wastes. ${ }^{66}$ Research presented at this symposium showed that the city of Portland contributed 89.6 per cent of the bacterial pollution of the lower Columbia, and Publishers' Pulp \& Paper Company's practice of barging its Oregon City mill wastes to the Columbia contributed 12.5 per cent of the nutrients necessary for slime growth. ${ }^{67}$

Following this symposium, the Oregon and Washington sanitary agencies and the USPHS announced a six-point plan to crack down on cities and industries. ${ }^{68}$ This plan demanded the cessation of untreated municipal and industrial waste discharges. The Oregonian published an editorial lauding this joint program and echoed pollution abatement advocates of the 1930s by finding that Oregon's laws were strict but inadequately enforced. ${ }^{69}$ Slime was not eradicated, however, until after the OSSA established requirements that pulp and paper mills no longer discharge any wood fibers in their effluent. ${ }^{70}$ Scientists had found that the fungus grew on these fibers and created large, drifting flocs of slime that would then get entangled in fishing nets. ${ }^{71}$

Technically part of the lower Columbia River, the Columbia Slough is a drastically different body of water as it is much smaller and practically stagnant. The slough separates the North Portland peninsula from Hayden Island. Since the nineteenth century, Euro Americans have used the slough as a working stream, much as they used the Willamette or Columbia rivers. Beginning in the mid-nineteenth century, barges transported log rafts by way of the slough, and shingle mills, meat 
processing plants, animal feed lots, and other industries had long used the slough as a waste sink. ${ }^{72}$ By the early 1940 s, the effects of this practice were readily apparent in water that was unfit even to float log rafts. ${ }^{73}$

Degraded conditions and regular complaints had motivated the OSSA for years to get the sixteen meat-industry companies located along the slough to stop dumping untreated wastes. The Sanitary Authority had informed these firms of their obligation to abate pollution in November 1946, November 1950, and October 1951. On four separate occasions after late 1951, the authority granted abatement extensions to individual plants along the slough, and in each instance plant representatives told the OSSA that they were waiting on Portland officials to connect effluent lines from their plants to the city's interceptor sewer. ${ }^{74}$

In September 1955, the OSSA determined to take legal action against ten of sixteen Columbia Slough meat industry firms if these facilities did not commence construction of waste disposal systems within sixty days. The authority initiated injunction proceedings against two meat industry companies in late 1955 for lack of adequate progress after years of extensions and warnings. ${ }^{75}$ Consistent authority pressure, including these punitive steps, motivated all Columbia Slough meat processing companies to begin building individual facility sewage treatment systems or connecting to Portland's sewer interceptor running through this area of the city by late $1956 .^{76}$

The inability of the Columbia Slough to assimilate wastes was a primary factor in the OSSA's approach. By the 1930s, public health and sanitary engineering 
specialists realized that hydrological conditions made the slough an inadequate repository even for treated wastes. Abel Wolman and his team expressed this conclusion clearly in their 1939 report. They contrasted the assimilative capacity of the slough with the observation that the Columbia River itself could, from an engineering perspective, assimilate 100 per cent of Portland's untreated municipal wastes. $^{77}$

Sanitary engineers were also aware that insufficient water levels in the Willamette during the late summer and early fall made the river less than an ideal waste sink. Seasonal water fluctuations became increasingly less extreme as Willamette System dams were completed in the 1940s and 1950s. Willamette Valley Project plans included pollution abatement as one of many positive benefits. ${ }^{78}$ Regulation of the river's flow led to some improvement in dissolved oxygen levels as early as $1953 .^{79}$ Once elements of the Willamette Valley project came on-line, however, a new issue arose, water-rights allocations.

The Oregon State Game Commission linked the September 1949 large-scale crawfish die-off near Scappoose, in part, to the over-allocation of water use rights that exacerbated seasonal low-flow conditions. Representatives of sportsmen's groups blamed the U.S. Army Corps of Engineers (USACE), the agency responsible for regulating reservoir levels. These critics perceived that the USACE did not release sufficient water because the agency was more concerned with maintaining water levels for recreationists at the Fern Ridge and Cottage Grove reservoirs along tributaries of the Willamette River. ${ }^{80}$ 
In early 1950, Governor Douglas McKay established an advisory committee on the state's natural resources to analyze the needs of parties with competing interests in Willamette Valley water allotments. ${ }^{81}$ Also during 1950 , President Truman's National Water Pollution Control Advisory Board included flow regulation and rights allocation as important aspects of their water quality research. Flow in the main stem of the Willamette nearly doubled during the traditional seasonal low-water months of July through October with the completion of the Detroit, Big Cliff, Lookout Point, and Dexter tributary dams in 1953 and 1954. Sanitary engineering experts asserted that the general improvement of Willamette River water quality beginning in the mid-1950s required augmented flow from tributary reservoirs as much as it required improved technologies and modified practices. ${ }^{82}$ Because of the direct link between water allocations and Willamette River water quality, in 1960 the OSSA took a resolution to the State Water Resources Board to guarantee sufficient stream flow during the low water months, thereby codifying such allocations as an integral pollution abatement measure. ${ }^{83}$ Although Attorney General Neuner had warned pulp and paper industry executives in 1950 not to rely upon augmented seasonal flows as part of their abatement plans, reservoirs in the Willamette watershed were nevertheless an essential part of the complex push to decrease water pollution. 
State and federal water pollution control on a treadmill

More people began using the Willamette River for recreation by the mid-1950s as water quality gradually improved. ${ }^{84}$ These improvements followed the completion of Portland's sewage treatment system, the pulp and paper industry's incremental abatement, and augmented flow from Willamette Valley Project reservoirs. Abatement advocates such as David Charlton continued to press the Sanitary Authority to confront industrial polluters with more force, particularly the pulp and paper industry, and OSSA members reacted to this pressure and evidence of environmental degradation while expanding their abatement efforts.

Congress passed a revised Water Pollution Control Act in 1956 in reaction to the same kinds of complexities experienced in Oregon. Continued pressure from grassroots organizations, such as the IWLA, helped bring about this legislation. ${ }^{85}$ Congress also strengthened national water pollution laws for economic development reasons because they were convinced that water quality was an important resource management issue.

Senator John Blatnik of Minnesota joined with federal public health officials in arguing for strengthening the 1948 legislation by explicitly linking water quality with economic development. Such correlation was not entirely new. The National Resources Council of the 1930s and President Truman's water pollution board in 1950 both made this connection. ${ }^{86}$ Water pollution abatement advocates in California and Oregon equated clean streams with the economic health of commercial fisheries in the 
late nineteenth and early twentieth centuries, and city officials garnered public support of Portland's $\$ 12$ million sewer bond measure in 1944 by correlating the project to post-war employment. ${ }^{87}$

The 1948 Water Pollution Control Act was the first comprehensive federal water quality legislation. Eight years later, what made the first permanent federal water pollution act significant was that it tied pollution abatement explicitly to substantial federal appropriations; it was, therefore, a measure for proactive economic considerations rather than a reaction against degraded water conditions. Blatnik and the act's other supporters used federal public works enticements to gain the support of state and municipal officials who had previously been opposed to such legislation. Along with this support came the compromise of a federal enforcement mechanism that was only minimally stronger than the 1948 act. $^{88}$

In October 1955, during Congressional debate on Blatnik's proposal, the Oregon Journal suggested that Oregon was now leading the nation in water pollution abatement. The newspaper compared Oregon's experience favorably with the movement to clean the Potomac River that was only then getting underway. ${ }^{89}$ However, by summer 1957, population growth and industrial expansion in Oregon were occurring at a rate that kept pace with sewage and industrial effluent treatment gains, effectively putting "river pollution control on a treadmill." ${ }^{\text {90 }}$ Oregonian editor Herbert Lundy quoted David Charlton:

in spite of construction of sewage treatment plants, water releases from two large reservoirs (Detroit and Lookout Point) and good water years, the water condition is at best marginal with respect to the return of the fall Chinook salmon which have been planted since $1952 .{ }^{91}$ 
Lundy's editorial echoed conclusions from an Oregonian editor the previous summer that the Willamette was "cleaner, but not clean." The river was still below the bare minimum 4 ppm dissolved oxygen requirement for fish in and near Portland, and at the Sellwood Bridge the Sanitary Authority discovered a high coliform bacteria count.

Residents of the valley had been hard at work addressing pollution sources but "new industries and more people have come to Oregon, increasing the problem." While more than 90 per cent of Oregon municipalities had built primary sewage treatment systems by summer 1956, these systems would be overloaded as populations increased with the result that insufficiently treated sewage would once again enter the river. "We have not licked the problem of stream pollution in Oregon," the editorial concluded; "rather, we are just holding our own in the battle to keep it from getting worse." ${ }^{.92}$ Nowhere in Oregon was this more apparent than in Portland.

Portland's insufficient sewer infrastructure (again)

Portland's long-awaited primary sewage treatment plant in North Portland was operational in early October 1951, although it was not officially dedicated until October 27, 1952. The plant could process 60 million gallons of sewage per day, a capacity Portland City Commissioner William A. Bowes asserted would not need expansion until Portland's population numbered one million; for comparison, the city's population in 1950 was $373,000 .^{93}$ 
An integral aspect of Portland's sewage project had been the construction of a testing laboratory. Engineers began sampling Willamette River water at this laboratory in the summer of 1949 to provide a baseline and continuing data on the impact of the improved sewer infrastructure. ${ }^{94}$ Portland's chief chemist reported in July 1952 that the quality of the Willamette River showed marked improvement as measured by both a decrease in bacteria counts and an increase in dissolved oxygen nine months after Portland's treatment plant had come online. This was a direct result of a ten-milliongallon-per-day decrease in untreated sewage dumped into the river. Before the plant became operational, the river and Columbia Slough received fifty million gallons of sewage per day. ${ }^{95}$

Portland city engineers measured a "record low" pollution level in late October 1953 after the last major east-side sewage lines serving the city's core were connected to the North Portland sewage treatment plant earlier that month. ${ }^{96}$ This achievement was, in the words of OSSA sanitary engineer Curtiss M. Everts, "the 'key' to the Willamette pollution puzzle."97

There were other important pieces of this puzzle as well. Until 1949, when primary sewage treatment plants in Junction City and Newberg came online, all cities along the Willamette River dumped untreated sewage into the river or its tributaries. All cities on the river had operational primary treatment facilities by 1957 after completion of Harrisburg's sewage treatment plant. ${ }^{98}$ The only cities with secondary sewage treatment by summer 1960 were Albany and Springfield. ${ }^{99}$ Primary treatment neutralized bacteria and removed all visible solid matter and approximately 33 percent 
of the biological oxygen demand (BOD) of the sewage, while secondary treatment removed approximately 90 percent of the BOD.

As Portland's primary treatment plant came online and as other Willamette Valley communities built primary and secondary treatment facilities, attention turned to areas of population growth without sewer infrastructure in the suburbs and urban fringes. Local officials had begun to address the sewerage needs of the suburbs southwest of Portland in 1953 by creating the West Slope Sanitary District and contracting for engineering studies for the approximately 600 square mile area. Although a bond issue to finance the district had failed in the November 1955 election, the Metropolitan Tri-Counties Health and Sanitation committee was "attacking the long-range problem." 100 In early February 1958, officials from Multnomah, Clackamas, and Washington counties agreed to a $\$ 27$ million sewer plan for the suburban area southwest of Portland. ${ }^{101}$ Construction of the first phases of the TriCounty Sewerage System began by September $1959 .{ }^{102}$

Progress addressing sewer infrastructure needs in the growing suburbs around Portland and in other Willamette Valley communities was proceeding by the late 1950s. However, in late 1956 there existed a "sewer emergency" within Portland. The extensive sewer line repairs required and the need to expand sewerage infrastructure into neighborhoods at the fringes of the city would take more than the $\$ 5$ million bond issue city officials had proposed for voters that November. The Oregonian saw this lack of foresight and piecemeal approach as a prime example of the city council's weaknesses in formulating long-term plans. ${ }^{103}$ 
In a comprehensive survey of river conditions in 1957, the Sanitary Authority found the river "still polluted to such an extent that it is not safe for certain recreational uses and occasionally in certain sections it is unsuitable for propagation or maintenance of fish life." 104 The authority's research led it to two important conclusions: primary municipal waste treatment was no longer sufficient in the Willamette Valley; and the city of Portland still lagged behind other municipalities because it had yet to connect thirty-five raw sewage outfalls from Linnton, Tryon Creek, and other outlying neighborhoods to the city's primary treatment plant. In reaction, the OSSA initiated another effort to compel compliance with Oregon's water pollution laws at its January 1958 meeting. ${ }^{105}$

Based on this information, the Oregon Journal called the goal of a clean river "far off." The so-called "Willamette river cleanup," the editorial noted, served as a model for abatement programs in other states, and state sanitary engineer Curtis M. Everts had earned national recognition for his work, but population increases and industrial expansion in the valley exceeded any previous gains from primary sewage treatment and pulp and paper industry abatement practices. ${ }^{106}$

The Portland City Club returned to the issue of water pollution abatement for the first time since the mid 1920s by producing a municipal sewage report in March 1958. The report observed that raw sewage from Portland neighborhoods continued to be a health hazard for swimmers and also drastically reduced dissolved oxygen levels during low-flow months. The report endorsed the tri-county sewage plan and advocated for renovation of Portland's inadequate sewer infrastructure, while also 
observing the reluctance of citizens and elected officials to take action until faced with "extreme circumstances." 107

These extreme circumstances finally moved citizens and elected officials to take action. About fifty abatement advocates organized in Salem on July 22, 1958, to begin lobbying all Willamette Valley cities to build secondary sewage systems. The committee spearheading this campaign represented various interests and included David Charlton, OSSA engineer Kenneth Spies, and a Salem real estate developer. ${ }^{108}$ Portland's City Council prepared a measure for the November 1958 ballot immediately following the organization of this advocacy group. This measure bundled \$5 million in capital improvements for Portland's sewer system with other projects into a $\$ 39,555,000$ package. The OSSA opposed this measure because it predicted that voters would be loathe to approve such a large amount. It reminded Portland mayor Terry Schrunk that city officials were under legal obligation to keep sewage from the Willamette River; therefore, if voters did not approve the package, the Sanitary Authority would be authorized to take legal action. ${ }^{109}$ As authority members feared, voters did not approve the measure. ${ }^{110}$

The Portland City Council offered a seven-point plan in the aftermath of the failed funding measure and in response to the authority's ultimatum to develop fiscal and construction proposals by January $15,1959 .{ }^{111}$ Commissioner Bowes and other city officials asserted that they were willing to do what they could but only insofar as funds would allow. The city carried a backlog of sewage disposal projects that included new treatment plants at Linnton and Guilds Lake and building interceptors 
for thirty-five untreated public and private outfalls. To correct these and other deficiencies, council members agreed to place yet another bond issue on the May 1960 ballot. ${ }^{112}$ Notwithstanding city officials' claim of insufficient funds, in early March 1959 the Sanitary Authority rejected the city's seven-point proposal and filed suit against the City of Portland for failure to comply with pollution abatement orders in a timely manner. ${ }^{113}$

Newspapers sided with the OSSA and other abatement advocates against Portland officials. The Oregonian put it in clear terms: Because the OSSA was advocating for health and welfare, it was "on the side of the angels," and Portland city leaders were clearly "aligned with the forces of evil."114 There had long been elements of morality in the approach of pollution abatement advocates, particularly in some Izaak Walton League members and in Oregon Journal and Oregonian editorials. However, this particular editorial expressed a level of unambiguous moralizing that reflected a growing ethical argument against water pollution within and beyond Oregon. ${ }^{115}$

Responding to the suit against Portland in early March 1959, Mayor Schrunk accused the authority of deliberately impinging upon the policy of home rule. He also warned that the OSSA's goal of completely eliminating water pollution within Portland city limits would signal an end to all manufacturing concerns and a corresponding loss of jobs. ${ }^{116}$ Portland's chief deputy city attorney said that city officials looked forward to the opportunity to challenge the validity of the state law empowering the OSSA. ${ }^{117}$ On November 24,1959 , the authority refused Portland's 
request to dismiss its legal action. Authority members did, however, follow the recommendation of Circuit Judge Frank Lonergan to seek mediation and subsequently postponed the scheduled court hearing. ${ }^{118}$

Debate between the OSSA and Portland city officials continued throughout 1960. Authority members received a letter from Commissioner Bowes on December 14 outlining the steps that Portland was then preparing to make to comply with the Sanitary Authority's order to upgrade and expand its sewer infrastructure. These steps included treating wastes discharged into the Columbia River after primary treatment by installing a chlorine treatment facility no later than summer 1961 . The city would also construct a secondary sewage system for the Tryon Creek area. The OSSA found these and other actions satisfactory and dismissed its lawsuit. ${ }^{119}$

Forcing the City of Portland to move forward in constructing additional municipal waste infrastructure was not an insignificant achievement for the Sanitary Authority. The OSSA and other abatement advocates repeatedly revisited the issue of Portland's discharge of inadequately treated wastes. City officials found that compliance with state water pollution regulations meant the investment of hundreds of millions of dollars on infrastructure. These investments would only be considered completely successful if the infrastructure functioned properly and became, thereby, an unseen part of the city, with pipes buried under the ground and treated effluent not polluting area waters. Even with increased federal funding available as a result of the 1948 and 1956 Federal Water Pollution Acts, Portland city leaders had a hard time 
coming up with sufficient money until the OSSA, Izaak Walton League, and other groups confronted its intransigence.

The increasing complexity of water pollution

In November 1959, the state legislature transferred the duties of the Oregon Air Pollution Authority to the OSSA, with the consequence that the authority's time devoted to water pollution decreased. ${ }^{120}$ The issue remained pressing, however: Sanitary Authority data from 1959 found that water pollution levels were only 16 per cent lower than in 1939, in spite of progress abating both municipal and industrial discharges and the regulated seasonal water flow enabled by the reservoirs of the Willamette Valley Project. ${ }^{121}$

The OSSA began to divide its time between water and air pollution at approximately the same time that federal involvement in the issue of water quality was expanding. By 1960, Public Health Service scientist Edward Eldridge headed the newly-established Portland technical research station. In this capacity, Eldridge was engaged in a "constant soap-box campaign" pushing for more research at regional universities. Eldridge also hosted semi-annual symposiums-one of which, in late 1958, had focused on the lower Columbia River slime problem. He was finding the issue to be increasingly more complex, particularly because of the wide variety of new chemicals being developed. ${ }^{122}$ Reflecting a growing understanding of the lessons of ecological science to issues of water quality, Eldridge's scientific and technological 
challenges included "discover[ing] means of permitting man to progress in his environment without destroying the natural organisms that make that environment possible."123

Local television correspondent Tom McCall was motivated by these concerns as well. He conceived, produced, and narrated a television documentary on Oregon's water and air pollution-Pollution in Paradise - that aired on November 21, 1962. McCall had been in contact with Charlton since at least 1954 and was familiar with the work of the IWLA and other local conservationists. In 1959, McCall received from the Portland Chapter of the Izaak Walton League the Beaver Award recognizing achievements in natural resources conservation for his work producing television commentaries. ${ }^{124}$ Pollution in Paradise built upon this earlier work and also marked an important shift in local grass-roots sentiment that reflected changing perceptions of the environment throughout the nation. ${ }^{125}$

Sanitary Authority members passed a resolution lauding McCall's documentary at their January 4, 1963, meeting. OSSA members saw the documentary as "fair and unbiased" and congratulated the Pioneer Broadcasting Company and KGW-TV for the documentary's important role in public education. The citation read, in part, that "support for pollution control activities can only be gained when the people and the industrial leaders of the state have been accurately informed of what has been accomplished and what problems remain."126

McCall found that air and water pollution were complex yet eminently solvable issues that threatened both economic and public health. McCall concluded: 
Some pollution is inescapable, especially in a society such as ours, whose commercial and domestic demands on water and air constantly accelerate. Thus, some water, for example, must be employed for diluting pollution. But how much, and what priorities should be given this use, are central to a great debate, on which the shape of this region and this nation's future could well hang. ${ }^{127}$

McCall expressed faith in state authorities tasked with addressing the issue, such as the OSSA, State Board of Health, and attorney general, and he also stressed that the state's citizens played as important a role. This perspective reflected McCall's populist approach that would earn him renown during his term as governor of Oregon. ${ }^{128}$

Responding to Pollution in Paradise, Donald Hillebrand wrote McCall in early 1963:

From what I read and hear on television I don't believe the pollution problem is over yet. When I look west from where we live a mess of smoke [from the Harvey Aluminum plant] often is coming out and no telling what goes into the river. ... Now a paper mill is planning to move to town so there will be some more mess for the fish to take in. ${ }^{129}$

McCall's documentary and Hillebrand's letter show that that even after nearly forty years of concerted efforts by pollution abatement advocates, the water pollution issue remained unresolved. By the end of 1962, the work to clean the Willamette River in many ways had just begun.

\footnotetext{
1 "Rivers Are Public, Too," Oregonian, Oct. 23, 1947, sec. 1, p. 12.

${ }^{2}$ David B. Charlton to The Honorable John A. Blatnik, March 15, 1948, folder Correspondence re: Water Pollution 1947-1948, box 18, David B. Charlton Papers (MSS 1900) [hereafter Charlton Papers], Oregon Historical Society Research Library, Portland, Oreg. [hereafter Oregon Historical Society].

${ }^{3}$ Jouni Paavola, "Interstate Water Pollution Problems and Elusive Federal Water Pollution Policy in the United States, 1900-1948," Environment and History 12:4 (2006), 442-446, 450.

${ }^{4}$ Paul Charles Milazzo, Unlikely Environmentalists: Congress and Clean Water, 1945-1972 (Lawrence, Kans., University Press of Kansas, 2006), 19-20.
} 
${ }^{5}$ See, for example, Carl Abbott, The Metropolitan Frontier: Cities in the Modern American West (Tucson, Ariz., University of Arizona Press, 1993); quote from p. 4; for aspects of the process of Portland's growth from a regional to a national city, see pp. 72-78.

${ }^{6}$ William G. Robbins, Landscapes of Conflict: The Oregon Story, 1940-2000 (Seattle, Wash., University of Washington Press, 2004), 10-11.

${ }^{7}$ State of Oregon, Progress Report of the Postwar Readjustment Commission, Jan. 1, 1947-Dec. 31, 1948 (Salem, Oreg., 1949), p. 4.

${ }^{8}$ The next three most populous cities and counties included Salem $(43,410)$ and Marion County $(101,401)$, Eugene $(35,879)$ and Lane County $(125,776)$, and Corvallis $(16,207)$ and Benton County $(31,570)$. See U.S. Bureau of the Census, Census of Population: 1950 Oregon-Volume II, Part 37, Characteristics of the Population, Number of Inhabitants, Oregon, 12-13, available at http://www.census.gov/prod/www/abs/decennial/1950.htm, accessed Oct. 6, 2008. Wartime and postwar expansion taxed sewerage infrastructures across the country. For the example of Houston, Texas, see Martin V. Melosi, "Sanitary Services and Decision Making in Houston, 1876-1945," Journal of Urban History 20:3 (May 1994), 387, 393-395.

${ }^{9}$ David B. Charlton to Clarence W. Klassen, Sept. 1, 1948, folder Correspondence re: Water Pollution 1947-1948, box 18, Charlton Papers. For Klassen's contribution to national industrial pollution management practices between the 1930s and 1970, see Hugh S. Gorman, "Laying the Foundation for the Control of Industrial Pollution, 1930-1970: Two Canals, A Refinery, and Clarence W. Klassen," Journal of Illinois History 8:3 (2005), 182-208.

${ }^{10}$ See Gregory Summers, Consuming Nature: Environmentalism in the Fox River Valley, 1850-1950 (Lawrence, Kans., University Press of Kansas, 2006), for an analysis of local Izaak Walton League of America (IWLA) involvement in water pollution abatement efforts along Wisconsin's Fox River.

${ }^{11}$ V. J. Meunch, President, Wisconsin Division, IWLA, to Charlton, Dec. 1, 1949, folder Correspondence re: Pollution 1949, box 18, Charlton Papers.

${ }^{12}$ William Voigt, Jr., Executive Director, IWLA, to Charlton and Meunch, Dec. 21, 1949, folder Correspondence re: Pollution 1949, box 18, Charlton Papers.

${ }^{13}$ Charlton was in direct contact with numerous industry representatives, media outlets, and engineers beyond Klassen in Illinois and Meunch and L. F. Warrick in Wisconsin, such as the Sulphite Pulp Manufacturers' Research League, Inc. and the Pennsylvania Department of Health. For one example of Charlton's contacts with international firms developing pollution abatement technologies, see Charlton to Dr. W. H. Stark, Vickers-Vulcan Process Engineering Co. Ltd., Montreal, Quebec, n.d. [ca. 1949], folder Correspondence re: Pollution 1949, box 18, Charlton Papers.

${ }^{14}$ Abatement advocates in other states were also not pushing for a "pristine" river. For this kind of advocacy in Pennsylvania, see Nicholas Casner, "Angler Activist: Kenneth Reid, the Izaak Walton League, and the Crusade for Federal Water Pollution Control," Pennsylvania History 66:4 (1999), 535-553; for Minnesota, see Thomas Howard Hayden (Paul E. Toren, ed.), Citizen Leadership in Conservation: The Minnesota Izaak Walton League, 1922-1973 (St. Paul, Minn., Izaak Walton League Minnesota Division, 2001) and Philip V. Scarpino, Great River: An Environmental History of the Upper Mississippi, 1890-1950 (Columbia, Mo., University of Missouri Press, 1985). For the use of streams as integral parts of municipal and industrial waste treatment systems, see Arn Keeling, "Urban Waste Sinks as a Natural Resource: The Case of the Fraser River," Urban History Review 34:1 (2005), 58-70.

${ }^{15}$ George H. Risley, Secretary, Portland Chapter, IWLA [membership solicitation form letter], n.d. [ca. 1943], folder Portland Chapter-Izaak Walton League 1943, box 8, Charlton Papers.

${ }^{16}$ Charlton to "The Editor," Springfield News, Aug. 3, 1951, folder Correspondence re: Water Pollution 1951-1958, box 18, Charlton Papers. For this same sentiment from pollution abatement advocates along Maine's Androscoggin River, see Richard W. Judd, "The Coming of the Clean Waters Acts in Maine, 1941-1961," Environmental History Review 14:3 (Fall 1990), 55. 
17 "Stream Pollution Program Draws Walton League Rap," Oregonian, Dec. 21, 1948, p. 12. The Oregon IWLA's 1948 report is also discussed in Robbins, Landscapes of Conflict, 254-255.

${ }^{18}$ For Charlton's materials to Sanitary Authority Chairman Harold Wendel, see Oregon State Sanitary Authority Meeting Minutes [hereafter OSSA Minutes] vol. 2, Aug. 20, 1948, pp. 119-120, Oregon State Department of Environmental Quality, Portland, Oreg. [hereafter Oregon DEQ].

${ }^{19}$ Weyerhaeuser constructed a pilot recovery plant in Longview in 1946. See "Pulp Wastes Solution Seen in Weyerhaeuser's Tests," Oregonian, March 24, 1950, sec. 2, p. 10.

20 "Stream Pollution Program Draws Walton League Rap."

${ }^{21}$ OSSA Minutes Dec. 2, 1948, vol. 2, p. 145.

22 "Session Open on Pollution," Oregonian, Feb. 18, 1949, sec. 1, p. 13. In addition to the 1948 IWLAA report, Peter W. Welch, representing the Federation of Community Clubs, had recently criticized the OSSA in radio addresses and public presentations; see OSSA Minutes July 11, 1947, vol. 2, p. 62 , April 11, 1947, vol. 2, pp. 52-55, and Feb. 25, 1949, vol. 2, pp. 162-163.

${ }^{23}$ OSSA Minutes Feb. 25, 1949, vol. 2, pp. 170-174.

24 "State Warns Pollution Must End," Oregonian, April 27, 1949, p. 1; see also OSSA Minutes April 26, 1949, vol. 2, pp. 179-196.

25 "State Warns Pollution Must End."

${ }^{26}$ OSSA Minutes May 9, 1950, vol. 2, pp. 230-234.

${ }^{27}$ The term "population equivalent" refers to an engineering measurement of the pollution load on a body of water. Untreated sewage from one hundred people would have a population equivalent of 100 ; primary treatment would reduce this sewage strength approximately 33 per cent, bringing the population equivalent to seventy-seven, and secondary treatment would reduce the strength approximately 90 per cent, bringing the population equivalent to ten.

${ }^{28}$ U.S. Bureau of the Census, Census of Population: 1950 Oregon-Volume II, Part 37, pp. 12-13.

${ }^{29}$ Glenn D. Carter, "Pioneering Water Pollution Control in Oregon," Oregon Historical Quarterly 107:2 (Summer 2006), 262.

30 "State Warns Pollution Must End"; see also OSSA Minutes April 26, 1949, vol. 2, pp. 190-195 and Carter, "Pioneering Water Pollution Control," 263.

${ }^{31}$ John T. Cumbler, "Conflict, Accommodation, and Compromise: Connecticut's Attempt to Control Industrial Wastes in the Progressive Era," Environmental History 5:3 (2000), 328.

${ }^{32}$ OSSA Minutes July 22, 1949, vol. 2, pp. 199-200.

33 "Pulp Wastes Solution Seen in Weyerhaeuser's Tests," Oregonian, March 24, 1950, sec. 2, p. 10.

${ }^{34}$ Terence Kehoe, Cleaning Up the Great Lakes: From Cooperation to Confrontation (DeKalb, Ill., Northern Illinois University Press, 1997), particularly 5-11.

${ }^{35}$ See, for example, Kenneth A. Reid, "Editorial: The Water Policy of the League," Outdoor America, January 1947, p. 3, and Casner, "Angler Activist."

${ }^{36}$ Walter Mattila, "Millions of Crawfish Perishing; Pollution Hits Hardy Bullheads," Oregon Journal, Sept. 18, 1949, p. A9.

37 "Industry Said Eager to Find Solution to River Pollution," Oregonian, Oct. 21, 1949, p. 19.

${ }^{38}$ Charlton to Wendel, Oct. 25, 1949, folder Correspondence re: Water Pollution 1949, box 18, Charlton Papers.

${ }^{39}$ OSSA Minutes Nov. 4, 1949, vol. 2, pp. 212-217.

40 "Crackdown on Pollution," Oregonian, Dec. 12, 1949, p. 12.

${ }^{41}$ "Freeing the River," Oregon Journal, Feb. 19, 1950, p. 18A.

${ }^{42}$ See Robbins, Landscapes of Conflict, 256-257. 
43 "Pollution Showdown," Oregon Journal, Feb. 17, 1950, p. 12.

44 "Pulp Concern Denies Threat," Oregonian; Feb. 18, 1950, sec. 3, p. 3. For Publishers' Pulp \& Paper Company's earlier threats of possible mill closures they attributed to OSSA policies, see OSSA: Minutes vol. 2, Nov. 4, 1949, pp. 212-217.

${ }^{45}$ For this analysis, see Robbins, Landscapes of Conflict, 257.

${ }^{46}$ For experiments in Oregon on the lagooning of sulfite wastes, see "Paper Mills to Investigate Lagooning Sulphite Waste," Oregonian, Feb. 17, 1950, p. 8.

47 "Sanitary Authority Issues Orders to Paper Mills on Waste Dumping," Oregon Journal, May 10, 1950, p. 2; "State Edict Orders End of Pollution," Oregonian, May 10, 1950, p. 1. For Attorney General Neuner's finding of fact, see OSSA Minutes May 9, 1950, vol. 2, pp. 230-236.

48 "River Waste Takes Toll," Oregonian, Sept. 21, 1950, sec. 1, p. 11. For a first-hand account of Authority practices and degraded river conditions along the Willamette River from the OSSA's first aquatic biologist, hired in 1956, see Carter, "Pioneering Water Pollution Control."

${ }^{49}$ Gleeson, The Return of a River, 24, 26.

50 "National Pollution Control Meetings Slated in Portland," Oregonian, May 23, 1950, sec. 1, p. 13; "Adviser Board to Tour Area," Oregonian, July 7, 1950, sec. 2, p. 7. See also "State's Water Draws Study," Oregonian, April 28, 1950, sec. 3, p. 8. President Harry Truman established his National Water Pollution Control Advisory Board in early 1950 to help realize the goals of the Federal Water Pollution Control Act of 1948.

51 "Pollution Board May Ask Congress for Funds for Columbia Research," Oregonian, July 12, 1950, sec. 2, p. 12; "Local, Federal Officials Discuss Northwest River Pollution Puzzle," Oregon Journal, July 11, 1950, sec. 1, p. 7; OSSA Minutes May 9, 1950, vol. 2, pp. 230-234.

52 OSSA Minutes Dec. 7, 1951, vol. 2, pp. 289-290.

${ }^{53}$ OSSA Chairman Wendel, for example, "refused to indorse the lagoon methods, and emphasized that the mills must develop a process to rid the river of sulfite pollution." See "Praise Given Paper Plants," Oregonian, June 2, 1951, sec. 1, p. 7; "Mills Praised on Cleansing," Oregonian, June 7, 1951, sec. 1, p. 19. In spite of Wendel's misgivings, the OSSA considered this practice an adequate short-term solution; see OSSA Minutes June 1, 1951, vol. 2, pp. 272-273, and Sept. 7, 1951, vol. 2, pp. 280-281.

54 "Gain in War on Pollution," Oregonian, Aug. 29, 1951, sec. 1, p. 14. Clackamas County expanded its program to use sulfite wastes as a road binder in 1952 and again in 1953. See "Roads to Get Sulphite Acid," Oregonian, Feb. 19, 1952, sec. 1, p. 9; "Roads Using Mill's Waste," Oregonian, July 17, 1953, sec. 1, p. 18.

55 "Plan Mapped for Sulphite," Oregonian, May 13, 1953, sec. 1, p. 19. OSSA Minutes Feb. 13, 1953, vol. 2, p. 364.

56 "Paper Firm Seeks to Halt Sulphite Stream Pollution," Oregonian, July 22, 1953, sec. 1, p. 1.

${ }^{57}$ Oregon counties stopped using sulfite wastes as a road binder some time later when experience showed that the practice kept down dust but tended to get washed off roads by rain and ended up in lakes and streams anyway. See Carter, "Pioneering Water Pollution Control," 263.

${ }^{58}$ OSSA Minutes March 21, 1952, vol. 2, pp. 293-297.

59 "Fighting Stream Pollution," Oregonian, March 28, 1952, sec. 1, p. 16.

60 "Our Rivers Come Clean," Oregonian, July 18, 1952, sec. 1, p. 18.

${ }^{61}$ John H. Lincoln and Richard F. Foster, Report on Investigation of Pollution in the Lower Columbia River (Salem, Oreg., Interstate Technical Advisory Committee, 1943).

${ }^{62}$ Lawrence Barber, "Pulp Mills Strive to Whip Pollution Problem in Columbia," Oregonian, March 15, 1953, sec. 1, p. 28.

${ }^{63}$ For reports on progress abating lower Columbia River slime pollution, see Lawrence Barber, "Pulp Mills Strive to Whip Pollution Problem in Columbia"; "Survey Made on Pollution," Oregonian, Sept. 
28, 1953, sec. 1, p. 19; and "Getting Together on Pollution," Oregon Journal, May 27, 1958, sec. 4, p. 4.

64 "Clean Rivers in Sight," Oregonian, Oct. 3, 1953, sec. 1, p. 10.

65 "Joint Pollution Control," Oregonian, May 28, 1958, p. 26. For the 1948 survey, see Frederic F. Fish and Robert R. Rucker, Pollution in the Lower Columbia Basin in 1948-with Particular Reference to the Willamette River. Special Scientific Report: Fisheries No. 30 (Washington, D.C., U.S. Department of the Interior U.S. Fish and Wildlife Service, June 1950).

${ }^{66}$ For proceedings of this conference, see Edward F. Eldridge, ed., Proceedings of the Third Pacific Northwest Symposium on Water Pollution Research: The Sphaerolitus (Slime) Problem, Sept. 10-11, 1958 (Portland, Oreg., U.S. Department of Health, Education, \& Welfare, Public Health Service, Region 9, 1958).

${ }^{67}$ Lawrence Barber, "Columbia Flow Said Polluted,” Oregonian, Sept. 11, 1958, sec. 1, pp. 1, 10, and Barber, "Conferees Urge Two-State Action to Remove Pollution," Oregonian, Sept. 12, 1958, sec. 1, p. 17. See also Barber, "Savants to Plan Control of Columbia River Slime," Oregonian, Aug. 22, 1958, sec. 1, p. 23.

68 “Columbia Pollution Attacked," Oregonian, Aug. 6, 1959, sec. 1, pp. 1, 9.

69 "New Attack on Pollution," Sunday Oregonian, Aug. 9, 1959, sec. 1, p. 30. See also Robbins, Landscapes of Conflict, 260-263.

${ }^{70}$ See "Antipollution Deadlines Set," Oregonian, Sept. 4, 1959, sec. 1, pp. 1, 19; see also "River Slime End Visioned," Oregonian, Sept. 22, 1959, sec. 1, p. 16.

${ }^{71}$ Carter, "Pioneering Water Pollution Control," 264.

${ }^{72}$ For a brief history of the Columbia Slough, see Lawrence Barber, Columbia Slough (Portland, Oreg., Columbia Slough Development Corporation, Oct. 1977). For an interpretation of the environmental history of the slough that finds evidence of environmental racism, see Ellen Stroud, "Troubled Waters in Ecotopia: Environmental Racism in Portland, Oregon," Radical History Review 74 (1999), 65-95.

73 "Shingle Men Tell of Filth," Oregonian, March 2, 1944, sec. 2, p. 3.

74 OSSA Minutes Oct. 23, 1953, vol. 3, pp. 2-4.

${ }^{75}$ See OSSA.Minutes Sept. 2, 1955, vol. 3, pp. 90-104, and Dec. 2, 1955, vol. 3, pp. 114-115.

${ }^{76}$ OSSA Minutes Sept. 7, 1956, vol. 3, p. 163.

${ }^{77}$ However, the authors recommended that Portland not discharge untreated effluent into the Columbia River, so as to avoid "any conceivable evidence of sewage discharge." Board of Review (R. H. Corey, Wellington Donaldson, Carl E. Green, and Abel Wolman), "Report on the Collection and Disposal of Sewage," Portland, Oreg., Aug. 19, 1939, p. 16, in folder 8402-01 Sewage Disposal Project-Sewage Collection and Disposal Report 1939, box 1, Public Works Administration-City Engineer's Historical/Subject Records, City of Portland Stanley Parr Archives and Records Center, Portland, Oreg.

${ }^{78}$ See William G. Robbins, Landscapes of Promise: The Oregon Story, 1800-1940 (Seattle, Wash., University of Washington Press, 1997), 238-295.

${ }^{79}$ Gleeson, The Return of a River, 62-63.

${ }^{80}$ Walter Mattila, "Millions of Crawfish Perishing; Pollution Hits Hardy Bullheads," Oregon Journal, Sept. 18, 1949, p. A9.

81 "State's Water Draws Study," Oregonian, April 28, 1950, sec. 3, p. 8.

${ }^{82}$ Gleeson, The Return of a River, 62-64.

${ }^{83}$ OSSA Minutes April 7, 1960, vol. 3, p. 362.

${ }^{84}$ OSSA Minutes Sept. 22, 1960, vol. 3, p. 396. 
${ }^{85}$ Richard W. Judd and Christopher S. Beach, Natural States: The Environmental Imagination in Maine, Oregon, and the Nation (Washington, D.C., Resources for the Future, 2003), 38-39.

${ }^{86}$ Richard W. Judd, "The Coming of the Clean Waters Acts in Maine, 1941-1961," Environmental History Review 14:3 (Fall 1990), 61-63; Milazzo, Unlikely Environmentalists, 17-37.

${ }^{87}$ For California, see Donald J. Pisani "Fish Culture and the Dawn of Concern Over Water Pollution," Environmental Review 8:2 (1984), 117-131; for Oregon, see Chapter 1 of this thesis. See also Virgil Smith, "Oregon Waters: Crystal Ball Shows Them Clean Again," Oregonian, Jan. 21, 1945, magazine section, p. 5.

${ }^{88}$ Milazzo, Unlikely Environmentalists, 17-37.

89 "Oregon Ahead in Stream Purity," Oregon Journal, Oct. 9, 1955, p. A22.

90 "Cleaner But Not Clean," Oregonian, Aug. 20, 1956, sec. 1, p. 10.

91 Herbert Lundy, "River Pollution Control on Treadmill," Oregonian, Aug. 15, 1957, sec. 1, p. 14.

92 "Cleaner But Not Clean." For a first-hand perspective by a former OSSA staff member on the growing complexity of water pollution, see Carter, "Pioneering Water Pollution Control," 264-270.

93 "Sewage Treatment Unit Operating; Completion of System Due by 1953," Oregonian, Oct. 7, 1951, sec. 1, p. 1. For 1950 population figure, see U.S. Bureau of the Census, .Census of Population: 1950 Oregon-Volume II, Part 37, p. 12.

${ }^{94}$ Ron Moxness, "Progress Report Made on \$16,000,000 Project," Sunday Oregonian, July 31, 1949, sec. 2, p. 6.

95 "Sewer Lines Link in River Marks Disposal Plan Gain," Oregonian, Oct. 3, 1952, sec. 1, p. 14.

96. "East Side Sewage Put Into Columbia," Oregonian, Oct. 6, 1953, sec. 1, p. 1; "Pump Helps Clean River, Move Wastes to Facility," Oregonian, Oct. 24, 1953, sec. 1, p. 7.

97 "Sewage Treatment Unit Operating." For the dedication ceremony, see "Rites Dedicate Sewage Plant," Oregonian, Oct. 27, 1952, sec. 1, p. 12, sec. 2, p. 4, and "Visiting Experts to Inspect City's Sewage Plant," Oregonian, Oct. 22, 1952, sec. 1, p. 1.

${ }^{98}$ OSSA Minutes Sept. 22, 1960, vol. 3, p. 394. Former OSSA fisheries biologist Glenn D. Carter is not entirely accurate in citing George Gleeson when he writes that "all communities along the main stem of the Willamette except for Portland had primary treatment facilities" by 1957 . The OSSA had to bring suit against Portland city officials for not expanding its sewage infrastructure to the Tryon Creek and Linnton areas, not connecting other outfalls, and because primary treatment was found not to be adequate for discharge into the lower Columbia River. However, most of the city's sewage was receiving primary treatment as of October 1952. Gleeson was asserting that not all of Portland's sewage was receiving primary treatment by 1957 . See Carter, "Pioneering Water Pollution Control," 260, and Gleeson, The Return of a River, 59.

${ }^{99}$ OSSA Minutes July 14, 1960, vol. 3, pp. 381-383.

100 "Master Sewage Plan," Oregonian, Nov. 11, 1955, sec. 1, p. 30.

101 "Tri-County Sewer Program Brings Flurry of Queries from Residents," Oregonian, Feb. 9, 1958, sec. 1, p. 38.

102 "Right from the Start," Oregonian, May 31, 1958, sec. 1, p. 10.

103 "Sewer Emergency," Oregonian, Oct. 20, 1956, sec. 1, p. 10. For the inability of Portland city officials to establish effective long-term urban infrastructure plans through the 1950s, see Abbott, Portland, 165.

${ }^{104}$ OSSA Minutes July 14, 1960, vol. 3, p. 381.

105 "Water Clean-Up Order Aimed at Cities, Firms," Oregonian, Jan. 25, 1958, sec. 1, p. 4. See also OSSA Minutes July 14, 1960, vol. 3, p. 381. For number of sewer outfalls, see "City Maps Pollution Campaign," Oregonian, Jan. 15, 1959, sec. 1, p. 1. 
106 “Clean River Goal Far Off," Oregon Journal, Jan. 30, 1958, sec. 4, p. 4.

107 "City Club Asks Action on Problem of Sewage," Oregonian, March 30, 1958, p. 21.

108 "River Waste Gets Study," Oregonian, July 23, 1958, sec. 1, p. 11.

109 "River Waste Gets Study"; OSSA Minutes vol. 3, Aug. 8, 1958, p. 252.

${ }^{110}$ OSSA Minutes Feb. 6, 1959, vol. 3, pp. 263-279.

${ }^{111}$ OSSA Minutes Oct. 17, 1958, vol. 3, pp. 256-260. See also "City Faces State Demand to Explain Pollution," Oregonian, Sept. 30, 1958, sec. 1, p. 1; "Pollution Ultimatum Given City," Oregonian, Oct. 18, 1958, sec. 1, pp. 1, 6.

112 "City Maps Pollution Campaign."

${ }^{113}$ OSSA Minutes Feb. 6, 1959, vol. 3, pp. 267-269. See also "City Faces Pollution Court Suit," Oregonian, Feb. 7, 1959, sec. 1, pp. 1, 6; "State Suit Asks City Stop 'Filth,"' Oregonian, March 3, 1959 , sec. 1 , p. 1 .

114 "We Want Clean River," Oregonian, Feb. 20, 1959, p. 30.

${ }^{115}$ For a detailed analysis of the explicit and implicit morality and religiosity in post-war environmentalism, see Thomas R. Dunlap, Faith in Nature: Environmentalism as Religious Quest (Seattle, Wash., University of Washington Press, 2004). For an interpretation of changes in Americans' conception of the environment in the post-war era based on the experiences of suburban residents, see Adam W. Rome, The Bulldozer in the Countryside: Suburban Sprawl and the Rise of American Environmentalism (Cambridge, U.K., Cambridge University Press, 2001).

116 "Mayor Snaps at Oregon Air, Sanitary Units," Oregonian, March 4, 1959, sec. 1, p. 1. The city was also being pressed by the State Air Pollution Authority.

117 "Pollution Law to be Tested by City," Oregonian, Aug. 7, 1959, sec. 1, p. 27.

118 "Sanitary Authority Delays River Pollution Hearing," Oregonian, Nov. 15, 1959, p. 15; sce also OSSA Minutes Nov. 24, 1959, vol. 3, pp. 315-316.

119 OSSA Minutes Dec. 15, 1960, vol. 4, pp. 33-35.

${ }^{120}$ For creation of the Air Pollution Authority in 1951 and absorption of this agency within the OSSA in 1959, see Oregon Department of Environmental Quality, "Administrative Overview, March 2003," http://arcweb.sos.state.or.us/recmgmt/sched/special/state/overview/19970007deqadov.pdf, accessed Oct. 9, 2008; for reference to the Authority's revised rules of procedure based on this change, see OSSA Minutes Nov. 24, 1959, vol. 3, pp. 311-312. Attention is measured in terms of relative coverage of water and air pollution issues in OSSA minutes from November 24, 1959, through January 4, 1963.

${ }^{121}$ See Watford Reed, "Dirty River: Big Swallow Dangerous," Oregon Journal, May 24, 1959, p. 2C; Reed, "Dirty River Once Stank, Killed Fish," Oregon Journal, May 25, 1959, p. 2B; and Reed, "Dirty River Cleanup Job Partly Done," Oregon Journal, May 26, 1959, p. 18A.

${ }^{122}$ Bob Boxberger, "Scientist Preaches Clean Stream Doctrine," Oregon Journal, May 25, 1960, p. 7; see also Boxberger, "Pollutants Gradually Stifling Many Forms of Aquatic Life," Oregon Journal, May 26, 1960, part 1, p. 6.

${ }^{123}$ Boxberger, "63 Research Projects Seek Key to Cause-Effect of Pollution," Oregon Journal, May 17, 1960 , part 1, p. 6.

${ }^{124}$ For contacts with Charlton, see Tom Lawson McCall to Charlton [hand-written "1954"], folder Correspondence re: Water Pollution 1951-58, box 18, Charlton Papers; for award, see "League Pays Honor to 4," Oregon Journal, Nov. 20, 1959 / Oregonian, Nov. 21, 1959, p. 4.

${ }^{125}$ See Brent Walth, Fire at Eden's Gate: Tom McCall \& the Oregon Story (Portland, Oreg., Oregon Historical Society Press, 1994), 134-137, for details of McCall's work on this documentary.

${ }^{126}$ OSSA Minutes Jan. 4, 1963, vol. 4, pp. 272-273. 
${ }^{127}$ Thomas L. McCall, producer, Pollution in Paradise, television documentary (Portland, Oreg., KGW-TV, 1962).

${ }^{128}$ For more analysis of this documentary and the significant role it played in McCall's career, see Robbins, Landscapes of Conflict, 266-280, and Walth, Fire at Eden's Gate, esp. 134ff.

${ }^{129}$ Donald Hillebrand to Tom McCall, n.d. [hand-written "April 3, 1963"], folder KGW 1956-1966, box 32, sub-series 10, series C, Thomas Lawson McCall Papers (MSS 625-1), Oregon Historical Society. Although no further identifying information is provided, Mr. Hillebrand likely lived near The Dalles, as he references ongoing struggles to get the Harvey Aluminum plant to abate its smoke pollution. 


\section{CONCLUSION}

\section{The Willamette River after Pollution in Paradise}

With the broadcast of Pollution in Paradise in November 1962, Tom McCall significantly increased his involvement in ongoing efforts to compel Portland city officials and the state's pulp and paper industry to take action to end Willamette River pollution. Efforts begun in 1926 finally contributed to the creation of the Oregon State Sanitary Authority (OSSA) in late 1938. Oregon pollution abatement advocates considered the successful 1938 votes to create the OSSA and fund Portland's sewers as the most practical measures possible, whether these advocates approached the issue from the perspective of conservation, public health, sanitary engineering, business development, or morality. In the 1940s and early 1950s the OSSA was able to claim some success, including getting Oregon cities to build primary sewage treatment plants and pulp and paper mills to regulate release of sulfite wastes. Continued environmental degradation, however, motivated McCall to produce his documentary.

Many Oregonians received McCall's Pollution in Paradise favorably. McCall's boss at KGW, Tom Dargan, sent copies of the film to educators and state legislators. In January 1963, seeking to influence the latter group at the beginning of the legislative session, Dargan scheduled another broadcast. Portland Senator Ted Hallock sponsored a bill in 1963 to strengthen Oregon's water pollution laws that, when passed, enabled the state to shut down polluters. This was the strongest environmental law in the country. ${ }^{1}$ 
Oregon voters elected Tom McCall secretary of state in 1964 and governor in 1966. Over his eight years as governor, McCall took a prominent position in a number of pressing environmental issues, including land use planning, recycling, nuclear waste disposal, beachfront development, the Willamette River Greenway, and water pollution. In April 1967, shortly after he took office as governor, McCall appointed himself to serve as interim chair of the Sanitary Authority upon the death of Harold Wendel. ${ }^{2}$ Long-time authority member Barney McPhillips recalled that "No governor before Tom ever cared much what we did. Tom was the only one to take an interest in what we were doing and push us. The only thing Tom didn't understand was that these things took time. He wanted action immediately."3

Under McCall's governorship, the OSSA was incorporated within Oregon's new Department of Environmental Quality (DEQ) in 1969, an administrative reorganization that also involved a further strengthening of state water, air, and land pollution laws. Under the leadership of L. B. Day, whom McCall hand-picked, and equipped with enhanced oversight and enforcement powers, the DEQ built upon the work of the OSSA and exceeded the achievements of its predecessor agency. All cities in the Willamette Valley had secondary treatment facilities in operation by 1972, and all industries (with one exception) were complying with state pollution regulations. ${ }^{4}$ Such achievements were what Ethel Starbird memorialized in her 1972 National Geographic article and what James Agee, head of the new federal Environmental Protection Agency, called the most effective water pollution regulations in the nation. ${ }^{5}$ Water pollution from point sources such as sewage outfalls and industrial effluent 
pipes had been drastically reduced. However, non-point sources of water pollution such as agricultural fertilizers, airborne herbicides and pesticides, and runoff from parking lots and streets increased the complexity of the issue. By the early 1990s, Oregon residents were asking if, alas, the Willamette was a "river restored?"6

In spite of such significant overall state achievements, well into the twentyfirst century periodic combined sewer overflows (CSOs) in Portland's harbor after heavy rains and accidents spurred health officials to warn against swimming in the Willamette. For example, In August 2007 health risks from a recent CSO threatened the cancellation of Portland's first downtown triathlon, and after heavy rains in May 2008, officials from Portland's Bureau of Environmental Services warned against engaging in any recreational activities in the Willamette River "during which water could be swallowed."7

Engineers built overflow sewer outlets into the Willamette River and Columbia Slough as integral parts of Portland's interceptor, pumping station, and treatment plant system that came online in 1953 . They designed or retained these outlets so that sewage would be released to these waterways rather than back up into the basements of homes and businesses during periods of excessive rainfall. ${ }^{8}$ Beginning in the early 1960s, the City of Portland began building separated sewage and storm water runoff systems for newly incorporated areas of the expanding city, negating the need for the same kinds of direct-to-the-waterway release valves. ${ }^{9}$ However, most of the city retained combined sewers through the twentieth century. 
The city began working to reduce the incidence of CSOs in 1991. A lawsuit from Northwest Environmental Advocates-another in a long line of citizens' groups pushing to clean the Willamette-helped spur this project. ${ }^{10}$ The city's program included \$146 million to separate sewer and storm water systems, install approximately 3,000 sumps to collect storm runoff, disconnect building downspouts from sewer lines, and divert streams such as Tanner Creek directed into sewer systems decades ago. ${ }^{11}$ The program also includes steps to alleviate non-point source pollution through a combination of urban infrastructure and engineering design elements such as building bioswales to absorb storm water and replacing conventional roofing with "ecoroofs"- a layer of foliage and a growing medium—to decrease storm water runoff from roofs while also providing insulation and other benefits. The project is slated to be completed in $2011 .^{12}$

Broader lessons learned from the example of Willamette River pollution abatement

Many pollution abatement advocates criticized the Sanitary Authority in the 1950s and 1960s, and some scholars still critique the authority's work. Brent Walth, for example, concludes that "overall the Sanitary Authority did a good job of convincing Oregonians that the Willamette was in fact growing cleaner all the time," in spite of evidence that it was not. ${ }^{13}$ It is the case that the OSSA did not achieve its goal of cleaning the Willamette or other Oregon streams. Historian William G. Robbins argues that this was due to a lack of political will at the state level. ${ }^{14}$ There 
are at least three additional reasons why this was the case. First-and related to Robbins' conclusion - the authority was working within the limits set by legislation, funding allocations, and staffing levels. Second, because judicial oversight had proven ineffective by the 1920s, state agencies used a cooperative pragmatic approach with polluters. This approach avoided costly litigation that was most often ineffective because it redressed grievances but did not establish proactive water quality standards or administrative practices; however, the cooperative pragmatic approach was not strong on compliance enforcement. Finally, until the mid-1950s, the water pollution problem seemed solvable, given the understanding of science and faith in expertise and technology.

Pollution abatement advocates first had to quantify the impacts, sources, and parameters of water pollution before taking other steps. Costly abatement solutions required money and resources to implement. They also required good data: no steps could be taken until the issue, parameters, and possible solutions were put in quantitative, empirical terms. People perceived of pollution as a problem when their accustomed economic and recreational activities were curtailed. Once viewed as a problem, advocates attempted legislative, administrative, and technological solutions. Scientific research was required to justify expenditures, but science alone was not enough to drive the abatement process.

Water pollution abatement methods and technologies evolved in conjunction with immediate requirements. Sanitary engineers through the 1960 s considered rivers, streams, and lakes as integral parts of urban sanitation infrastructure; making these 
bodies of water serve multiple uses, including diluting and assimilating wastes, was a "reasonable use," in conservation terms. In this context, the application of the idea of "assimilative capacity" was the first attempt to provide a rational scientific understanding to the disposal of municipal and industrial wastes, and was a significant departure from the casual approaches that predominated through the nineteenth century. ${ }^{15}$ Officials from state and federal agencies and others involved in Willamette River water pollution abatement, such as David Charlton, took advantage of the trials and successes in other locations. Events in Oregon proceeded with the benefit of-and contributed to-advances in the rest of the nation.

There were a variety of reasons why it was easier for the OSSA to mandate that cities intercept and treat their sewage than it was for them to mandate that pulp and paper wastes be treated. First, effective municipal sewage treatment systems were developed by the 1910s, but technologies to treat or reuse of sulfite wastes were still being developed into the mid-1950s. Second, sewage represented more of a public health hazard than pulp mill wastes, and, therefore, caught the attention of state agencies. Third, many pollution abatement advocates held a fear, either real or perceived, that the state would lose jobs because of industry relocation if firms felt pressed by pollution regulations. Finally, the OSSA, through the federal government, was able to subsidize engineering, planning, and implementation of municipal sewage infrastructure, an active step that government was not empowered to do for industry.

Questions of funding dominated the abatement issue after creation of the Sanitary Authority in 1939. It is true that sufficient resources to move forward with 
large-scale infrastructure projects were not always easy to come by during the Great Depression and World War II, even considering New Deal funding opportunities. It may seem at first glance that lack of money was what stalled the pollution abatement work. However, a more compelling question is: What changed in the critical mass to get people to re-allocate resources to abate pollution? In the case of water pollution and other kinds of environmental impacts, environmental limitations combine with ideology, morality, and economics as critical elements spurring changes in individual and social behavior. This is because negative environmental impacts constrain choices, choices constrained spur discomfort, and the resulting discomfort then leads people to act.

The vast majority of Oregon citizens involved in Willamette River cleanup efforts wanted to create a healthier "working river," not a pristine, pre-contact watershed. ${ }^{16}$ Even the most activist members of the pollution abatement community conceived of the river in terms of a shared resource to be used for a variety of purposes. A broad spectrum of citizens supported the goal of cleaning up the Willamette so that human and piscatorial health could be sustained and future recreational and economic opportunities not be curtailed. That this goal was not achieved by 1938 - or even by 1962 - brings to light the complex nature of Oregonians' relationship to the environment and highlights the often slow and arduous process to make fundamental changes to laws, technologies, and practices that reflect this relationship. 
The preceding analytical focus on the more pragmatic aspects of the water pollution abatement issue qualifies but does not necessarily overturn the conclusions of scholars that emphasize "forces" or "impulses." Historians Richard W. Judd and Christopher S. Beach frame their analysis of Oregon's and Maine's environmental history in terms of an "environmental imagination" that has two aspects, the "pastoral" and the "wilderness." They assert that the former is rooted in a romanticization of rural America traced to Thomas Jefferson, the latter in a romanticization of untrammeled nature John Muir espoused in the nineteenth century. Upon reading their analysis, however, one is left wondering what the vast majority of people involved in environmental issues who were not politicians or articulate writers did, said, and thought: Samuel Hays recognizes that uncovering peoples' motivations relative to the environment requires the historian to locate a population within a specific society and in a specific place, yet he elevates the choices that stem from this approach into an "environmental impulse" seemingly outside human agency. Seeking to ground (aptly) what he sees as too much "imagination," "impulse," and ideology in writing on urban environmental history, geographer Matthew Gandy nevertheless loses his connection with the pragmatic and the "folk" when he focuses more on critiquing the works of others than he does on the actions and expressed lived experience of his generalized New Yorkers. ${ }^{17}$

As David B. Charlton asked near the end of his career in 1975, who where the people actively involved in Willamette River water pollution abatement before Tom McCall? Charlton drew attention to the concerted efforts of ad hoc organizations, state 
officials, and members of conservation groups such as the Waltonians. Additional individuals included William L. Finley, Harold Wendel, John C. Veatch, Kenneth Spies, and William Joy Smith, and other organizations include the Anti-Stream Pollution League, Advisory Committee on Stream Purification, and the Oregon Stream Purification League. Even the often-critiqued Oregon State Sanitary Authority, as a body, contributed to the overall efforts. Echoing the complex nature of water pollution itself, these and other advocates contributed in a variety of ways and for a variety of reasons.

Life-long conservationists such as naturalist William L. Finley were as prepared to use economic arguments supporting pollution abatement as Chamber of Commerce representatives were. In addition to economic arguments, editors at the Oregon Journal and Oregonian used increasingly strong moral language to frame critiques of the companies that supplied the newspaper upon which their pointed editorials were written. Portland City Commissioner Ormand Bean spearheaded an initiative to fund city sewerage infrastructure in no small part to employ people out of work during the Great Depression. Yet Bean and other city officials fought the OSSA during World War II to avoid levying the full service charge to put returning veterans to work. David Charlton provided leadership by forging cooperative relationships with a variety of professionals and state officials across the nation while concurrently lambasting his own state's sanitary authority for not forcing the pulp and paper industry to abate pollution immediately. 
Such webs of motivations and interests defined the conflict between those advocating for pollution abatement and resistance to abatement measures on the part of Portland city officials and pulp and paper industry representatives. This dynamic continued as negative environmental impacts intensified within the Willamette and lower Columbia watersheds, as scientific tools and approaches were refined to quantify these negative impacts, and as increasingly more Oregonians became actively involved in the issue. What we learn from this is that both the environment and we actors upon its stage are much more complex than we generally suppose.

\footnotetext{
'Brent Walth, Fire at Eden's Gate: Tom McCall \& the Oregon Story (Portland, Oreg., Oregon Historical Society Press, 1994), 147. For text of this law, see Chapter 171, General Laws of Oregon, 1963, pp. 235-239.

${ }^{2}$ Walth, Fire at Eden's Gate, 183.

${ }^{3}$ Barney McPhillips' quote from William G. Robbins, Landscapes of Conflict: The Oregon Story, 19402000 (Seattle, Wash., University of Washington Press, 2004), 269.

${ }^{4}$ William G. Robbins' describes the work of the Sanitary Authority, Department of Environmental Quality, and Governor Tom McCall on the water pollution issue from 1963 through the 1970s; see Robbins, Landscapes of Conflict, 268-272.

${ }^{5}$ For Ethel Starbird's article, see “A River Restored: Oregon's Willamette," National Geographic 141:6 (June 1972), 816-834.

${ }^{6}$ For an analysis of the efforts to sustain the Willamette River pollution abatement momentum of the late 1960s and early 1970s into the twenty-first century, see Neil Mullane, "The Willamette River of Oregon: A River Restored?" in Antonius Laenen and David A. Dunnette, eds., River Quality: Dynamics and Restoration (Boca Raton, Fla., Lewis Publishing, 1997), 65-76.

${ }^{7}$ Scott Learn, "Accidental Sewer Overflow May Affect Triathlon Swim," Oregonian Aug. 31, 2007, http://blog.oregonlive.com/breakingnews/2007/08/supporters_of_portlands_first.html, accessed Sept. 30, 2008. Quote from "Officials: Don't Swim, Fish in the Willamette River for 48 Hours," Oregonian, May 20, 2008, http://blog.oregonlive.com/breakingnews/2008/05/officials_dont_swim_fish_in_ th.html, accessed Sept. 30, 2008.

${ }^{8}$ Portland Bureau of Environmental Services, "Combined Sewer Overflow (CSO) Program," http://www.portlandonline.com/bes/index.cfm?c=31030\&a=47260, accessed Sept. 30, 2008. Many people refer to this project as the "Big Pipe."

9 "Combined Sewer Overflow (CSO) Program."

${ }^{10}$ See Ellen Stroud, "Troubled Waters in Ecotopia: Environmental Racism in Portland, Oregon," Radical History Review 74 (1999), 89-90. Another group organized a "Riverfest 08" educational and recreational event in late summer 2008, with the motto "The Willamette: Respect, Reconnect, Renew"; see http://www.portlandriverfest.org/, accessed Sept. 30, 2008.

11 "Combined Sewer Overflow (CSO) Program."
} 
${ }^{12}$ Portland Bureau of Environmental Services, "Sustainable Stormwater Management," http://www.portlandonline.com/bes/index.cfm?c=31030\&a=201839, accessed Sept. 30, 2008. See also commentary on Portland City Commissioner Sam Adams' "Gray to Green" initiative involving these and other elements; Bob Sallinger and Mike Houck, "A New Approach to Portland Watersheds," Oregonian, April 16, 2008, available at http://www.commissionersam.com/files/ Oregonian\%20Opinion\%20Page.pdf, accessed April 17, 2008.

${ }^{13}$ Walth, Fire at Eden's Gate, 141.

${ }^{14}$ Robbins, Landscapes of Conflict, 260.

${ }^{15}$ Arn Keeling, "Urban Waste Sinks as a Natural Resource: The Case of the Fraser River," Urban History Review 34:1 (2005), 66-67.

${ }^{16}$ For more on the continued importance of Portland Harbor as part of this "working river," see Carl Abbott, "Rivers Still Run Through It," Oregonian, Jan. 13, 2008, available at http://www. columbiacorridor.org/news/2008/jan/rivers.pdf, accessed Jan. 18, 2008.

${ }^{17}$ Judd and Beach, Natural States; Samuel P. Hays, Explorations in Environmental History: Essays (Pittsburgh, Pa., University of Pittsburgh Press, 1998); Matthew Gandy, Concrete and Clay: Reworking Nature in New York City (Cambridge, Mass., The MIT Press, 2002). 


\section{REFERENCES}

\section{Government Publications \& Organization Reports}

Amberg, Herman R. Bacterial Fermentation of Spent Sulphite Liquor for the Production of Protein Concentrate Animal Feed Supplement, Bulletin Series, No. 38. Corvallis, Oreg., Oregon State Agricultural College Engineering Experiment Station, [Oct.] 1956.

Board of Consulting Engineers on Sewage Disposal (Ray E. Koon, John W.

Cunningham, and Robert G. Dieck). Report on General Survey of the Problems of Sewage Treatment and Disposal in Willamette River Valley Oregon. Salem, Oreg., State of Oregon Reconstruction Advisory Board, [Aug.] 1933.

Board of Review (R. H. Corey, Wellington Donaldson, Carl E. Green, and Abel Wolman), "Report on the Collection and Disposal of Sewage," Portland, Oreg., Aug. 19, 1939.

Dimick, R. E., and Fred Merryfield. The Fishes of the Willamette River System in Relation to Pollution, Bulletin Series, No. 20. Corvallis, Oreg., Oregon State Agricultural College Engineering Experiment Station, [June] 1945.

Eldridge, Edward F., ed. Proceedings of the Second Pacific Northwest Symposium on Water Pollution Research: Financing Water Pollution Research Projects, Jan. 20, 1958. Portland, Oreg., U.S. Department of Health, Education, \& Welfare, Public Health Service, Region 9, 1958.

Eldridge, Edward F., ed. Proceedings of the Third Pacific Northwest Symposium on Water Pollution Research: The Sphaerolitus (Slime) Problem, Sept. 10-11, 1958. Portland, Oreg., U.S. Department of Health, Education, \& Welfare, Public Health Service, Region 9, 1958.

Eldridge, Edward F., ed. Proceedings of the Eleventh Pacific Northwest Symposium on Water Pollution Research: The Social and Economic Aspects of Water-Resource Quality Control, November 8 and 9, 1962. Portland, Oreg., U.S. Department of Health, Education, \& Welfare, Public Health Service, Region 9, 1962.

Fish, Frederic F., and Robert R. Rucker. Pollution in the Lower Columbia Basin in 1948-with Particular Reference to the Willamette River. Special Scientific Report: Fisheries No. 30. Washington, D.C., U.S. Department of the Interior U.S. Fish and Wildlife Service, June 1950. 
Gleeson, George W. A Sanitary Survey of the Willamette River from Sellwood Bridge to the Columbia River, Bulletin Series, No. 6. Corvallis, Oreg., Oregon State Agricultural College Engineering Experiment Station, [April] 1936.

Gleeson, George W., and Fred Merryfield, Industrial and Domestic Wastes of the Willamette Valley, Bulletin Series, No. 7 (parts 1, 2, and 3). Corvallis, Oreg., Oregon State Agricultural College Engineering Experiment Station, [May] 1936.

Izaak Walton League of America. "Dynamic Action: A Record of Goals and Accomplishments by Izaak Walton League Divisions and Chapters." Chicago, Ill., Izaak Walton League of America, 1946.

The League of Women Voters Education Fund. The Big Water Fight: Trials and Triumphs in Citizen Action on Problems of Supply, Pollution, Floods, and Planning across the U.S.A. Brattleboro, Vt., The Stephen Greene Press, 1966.

Langton, C. V., and H. S. Rogers. Preliminary Report on the Control of Stream Pollution in Oregon, Bulletin Series, No. 1. Corvallis, Oreg., Oregon State Agricultural College Engineering Experiment Station, [March] 1929.

Lincoln, John H., and Richard F. Foster. Report on Investigation of Pollution in the Lower Columbia River. Salem, Oreg., Interstate Technical Advisory Committee, 1943.

Merryfield, Fred. A Preliminary Survey of Industrial Pollution of Oregon Streams. Portland, Oreg., Oregon State Planning Board, [June] 1937.

Merryfield, Fred. "Stream Pollution Studies - 1944: Preliminary Report Submitted to Governor's Special Committee, Oregon State Sanitary Authority." Corvallis, Oreg., Oregon State Agricultural College Engineering Experiment Station, [January] 1945.

Merryfield, Fred, W. B. Bollen, and F. C. Kachelhoffer. Industrial and City Wastes, Bulletin Series, No. 22. Corvallis, Oreg., Oregon State Agricultural College Engineering Experiment Station, [March] 1947.

Merryfield, Fred, and W. G. Wilmot. 1945 Progress Report on Pollution of Oregon Streams, Bulletin Series, No. 19. Corvallis, Oreg., Oregon State Agricultural College Engineering Experiment Station, [June] 1945.

Moses, Robert. Portland Improvement. New York, William E. Rudge's Sons, Nov. 10, 1943. 
Northcraft, Martin, and Warren C. Westgarth. Oregon State Water Resources Board, Bulletin No. 2: Water Quality Data Inventory Supplement. Corvallis, Oreg., Oregon State College Engineering Experiment Station, [June] 1957.

National Resources Committee. Progress Report with Statements of Coordinating Committees. Washington, D.C., U.S. Government Printing Office, June 15, 1936.

National Resources Committee. Regional Planning Part I-Pacific Northwest. Washington, D.C., U.S. Government Printing Office, May 1936.

National Resources Committee Special Advisory Committee on Water Pollution. Report on Water Pollution. Washington, D.C., U.S. Government Printing Office, July 1935; reprint Feb. 1936.

National Resources Committee Special Advisory Committee on Ẇater Pollution. Water Pollution in the United Siates. Washington, D.C., U.S. Government Printing Office, 1939.

Oregon State Planning Board Advisory Committee on Stream Purification. Efforts to Reduce Stream Pollution in Oregon. Portland, Oreg., Oregon State Planning Board, [Feb.] 1937.

Oregon State Water Resources Board. First Biennial Report. Salem, Oreg., Oregon State Water Resources Board, [Jan.] 1957.

Oregon State Water Resources Board. Middle Willamette River Basin. Salem, Oreg., Oregon State Water Resources Board, [June] 1963.

Oregon State Water Resources Board. Willamette River Basin. Salem, Oreg., Oregon State Water Resources Board, [June] 1967.

Rodgers, H. S., C. A. Mockmore, and C. D. Adams. A Sanitary Survey of the Willamette Valley, Bulletin Series, No. 2. Corvallis, Oreg., Oregon State Agricultural College Engineering Experiment Station, [June] 1930.

Ronchetto, John C. An Analytical Digest of Existing Legislation of Oregon and Other States Relating to Stream Pollution. Salem, Oreg., Oregon State Planning Board Advisory Committee on Stream Purification, Aug. 1936.

Ronchetto, John C. Recommended Principles for Stream Purification Legislation in Oregon. Salem, Oreg., Oregon State Planning Board Advisory Committee on Stream Purification, June 1937. 
State of Oregon. Progress Report of the Postwar Readjustment Commission [biennial]. Salem, Oreg., 1943-1948.

U.S. Federal Security Agency, Public Health Service, Division of Water Pollution Control. Pacific Northwest Drainage Basins Summary Report on Water Pollution. Washington, D.C., U.S. Government Printing Office, 1951.

U.S. Department of Health, Education, and Welfare, Public Health Service. Proceedings: The National Conference on Water Pollution, December 12-14, 1960, Sheraton-Park Hotel, Washington, D.C. Washington, D.C., U.S. Government Printing Office, 1961.

\section{Books, Theses, \& Dissertations - General}

Bowler, Peter J. The Norton History of the Environmental Sciences. New York, W. W. Norton \& Company, 1993.

Buttenweiser, Ann L. Manhattan Water-Bound: Planning and Developing Manhattan's Waterfront from the Seventeenth Century to the Present. New York, New York University Press, 1987.

Duffy, John. The Sanitarians: A History of American Public Health. Urbana, Ill., University of Illinois Press, 1990.

Dunlap, Thomas R. Faith in Nature: Environmentalism as Religious Quest. Seattle, Wash., University of Washington Press, 2004.

Elkind, Sarah S. Bay Cities and Water Politics: The Battle for Resources in Boston and Oakland. Lawrence, Kans., University Press of Kansas, 1998.

Gandy, Matthew. Concrete and Clay: Reworking Nature in New York City. Cambridge, Mass., The MIT Press, 2002.

Goldman, Joanne Able. Building New York's Sewers: Developing Mechanisms of Urban Management. West Lafayette, Ind., Purdue University Press, 1997.

Hayden, Thomas Howard (Paul E. Toren, ed.). Citizen Leadership in Conservation: The Minnesota Izaak Walton League, 1922-1973. St. Paul, Minn., Izaak Walton League Minnesota Division, 2001.

Hays, Samuel P. Explorations in Environmental History: Essays. Pittsburgh, Pa., University of Pittsburgh Press, 1998. 
Kehoe, Terence. Cleaning Up the Great Lakes: From Cooperation to Confrontation. DeKalb, Ill., Northern Illinois University Press, 1997.

Klingle, Matthew. Emerald City: An Environmental History of Seattle. New Haven, Conn., Yale University Press, 2007.

Melosi, Martin V. The Sanitary City: Urban Infrastructure in America from Colonial Times to the Present. Baltimore, Md., Johns Hopkins University Press, 2000.

Milazzo, Paul Charles. Unlikely Environmentalists: Congress and Clean Water, 19451972. Lawrence, Kans., University Press of Kansas, 2006.

Minteer, Ben A. The Landscape of Reform: Civic Pragmatism and Environmental Thought in America. Cambridge, Mass., The MIT Press, 2006.

Murphy, Priscilla Coit. What a Book Can Do: The Publication and Reception of Silent Spring. Amherst, Mass., University of Massachusetts Press, 2005.

Ohanian, Nancy Kane. The American Pulp and Paper Industry, 1900-1940: Mill Survival, Firm Structure, and Industry Relocation. Westport, Conn., Greenwood Press, 1993.

Reiger, John F. American Sportsmen and the Origins of Conservation (third edition). Corvallis, Oreg., Oregon State University Press, 2001.

Rome, Adam W. The Bulldozer in the Countryside: Suburban Sprawl and the Rise of American Environmentalism. Cambridge, U.K., Cambridge University Press, 2001.

Scarpino, Philip V. Great River: An Environmental History of the Upper Mississippi, 1890-1950. Columbia, Mo., University of Missouri Press, 1985.

Skowronek, Stephen. Building a New American State: The Expansion of National Administrative Capacities, 1877-1920. Cambridge, U.K., Cambridge University Press, 1982.

Steinberg, Theodore. Nature Incorporated: Industrialization and the Waters of New England. Amherst, Mass.; University of Massachusetts Press, 1994.

Stradling, David. Smokestacks and Progressives: Environmentalists, Engineers and Air Quality in America, 1881-1951. Baltimore, Md., Johns Hopkins University Press, 1999. 
Summers, Gregory. Consuming Nature: Environmentalism in the Fox River Valley, 1850-1950. Lawrence, Kans., University Press of Kansas, 2006.

Tarr, Joel A. The Search for the Ultimate Sink: Urban Pollution in Historical Perspective. Akron, Ohio, University of Akron Press, 1996.

\section{Books, Theses, \& Dissertations - Specific to Oregon, the Willamette River, Portland, etc.}

Abbott, Carl. Portland: Planning, Politics, and Growth in a Twentieth-century City. Lincoln, Nebr., University of Nebraska Press, 1983.

Abbott, Carl. The Metropolitan Frontier: Cities in the Modern American West. Tucson, Ariz., University of Arizona Press, 1993.

Caldwell, Lynton K., Lynton R. Hayes, and Isabel M. MacWhirter. Citizens and the Environment: Case Studies in Popular Action. Bloomington, Ind., Indiana University Press, 1976.

Gleeson, George W. The Return of a River: The Willamette River, Oregon. Corvallis, Oreg., Oregon State University Water Resources Research Institute, 1972.

Judd, Richard W., and Christopher S. Beach. Natural States: The Environmental Imagination in Maine, Oregon, and the Nation. Washington, D.C., Resources for the Future, 2003.

Lipin, Lawrence M. Workers and the Wild: Conservation, Consumerism, and Labor in Oregon, 1910-30. Urbana, Ill., University of Illinois Press, 2007.

McKinley, Charles. Uncle Sam in the Pacific Northwest: Federal Management of Natural Resources in the Columbia River Valley. Berkeley, Calif., University of California Press, 1952.

MacColl, E. Kimbark. The Growth of a City: Power and Politics in Portland, Oregon, 1915-1950. Portland, Oreg., The Georgian Press, 1979.

Mauldin, Frank. Sweet Mountain Water: The Story of Salem, Oregon's Struggle to Tap Mt. Jefferson Water and Protect the North Santiam River. Salem, Oreg., Oak Savanna Publishing, 2004.

Noble, Richard Earle. "The Willamette River Fishes as Biological Indicators of Pollution." MS thesis, Oregon State College, Corvallis, Oreg., 1952. 
Orr, Elizabeth, and William Orr. Oregon Water: An Environmental History. Portland, Oreg., Inkwater Press, 2005.

Robbins, William G. Landscapes of Conflict: The Oregon Story, 1940-2000. Seattle, Wash., University of Washington Press, 2004.

Robbins, William G. Landscapes of Promise: The Oregon Story, 1800-1940, Seattle, Wash., University of Washington Press, 1997.

Walth, Brent. Fire at Eden's Gate: Tom McCall \& the Oregon Story. Portland, Oreg., Oregon Historical Society Press, 1994.

\section{Articles \& Book Chapters - General}

Barles, Sabine, and Laurence Lestel. "The Nitrogen Question: Urbanization, Industrialization, and Water Quality in Paris, 1830-1939." Journal of Urban History 33:5 (July 2007), 794-812.

Burke, John G. "Wood Pulp, Water Pollution, and Advertising." Technology and Culture 20:1 (Jan. 1979), 175-195.

Casner, Nicholas. "Angler Activist: Kenneth Reid, the Izaak Walton League, and the Crusade for Federal Water Pollution Control." Pennsylvania History 66:4 (1999), 535-553.

Casner, Nicholas. "Polluter versus Polluter: The Pennsylvania Railroad and the Manufacturing of Pollution Policies in the 1920s." Journal of Policy History 11:2 (1999), 179-200.

Colten, Craig E. "Illinois River Pollution Control, 1900-1970," in Lary M. Dilsaver and Craig E. Colten, eds. The American Environment: Interpretations of Past Geographies. Lanham, Md., Rowman \& Littlefield, 1992, pp. 254-272.

Colten, Craig E. "Contesting Pollution in Dixie: The Case of Corney Creek." Journal of Southern History 72:3 (Aug. 2006), 605-634.

Cumbler, John T. "Conflict, Accommodation, and Compromise: Connecticut's Attempt to Control Industrial Wastes in the Progressive Era." Environmental History 5:3 (2000), 314-335.

Egerton, Frank N. "Pollution and Aquatic Life in Lake Erie: Early Scientific Studies." Environmental Review 11:3 (Fall 1987), 189-206. 
Erspamer, August S., and William D. Rice. "Treatment of Pulp and Paper Mill Waste," Industrial and Engineering Chemistry 41:8 (Aug. 1949), 1806-1809.

Goddard, Nicholas. "'A mine of wealth'? The Victorians and the Agricultural Value of Sewage." Journal of Historical Geography 22:3 (1996), 274-290.

Gorman, Hugh S. "Laying the Foundation for the Control of Industrial Pollution, 1930-1970: Two Canals, A Refinery, and Clarence W. Klassen." Journal of Illinois History 8:3 (2005), 182-208.

Harmon, Rick. "The Bull Run Watershed: Portland's Enduring Jewel." Oregon Historical Quarterly 96:2/3 (Summer/Fall 1995), 242-270.

Harris, Glenn, and Seth Wilson. "Water Pollution in the Adirondack Mountains: Scientific Research and Governmental Response, 1890-1930." Environmental History Review 17:4 (Winter 1993), 47-72.

Judd, Richard W. "The Coming of the Clean Waters Acts in Maine, 1941-1961." Environmental History Review 14:3 (Fall 1990), 51-74.

Keeling, Arn. "Sink or Swim: Water Pollution and Environmental Politics in Vancouver, 1889-1975.” BC Studies 142/143 (Summer/Autumn 2004), 69-101.

Keeling, Arn. "Urban Waste Sinks as a Natural Resource: The Case of the Fraser River." Urban History Review 34:1 (2005), 58-70.

Kehoe, Terence. "The Persistence of Cooperation: Government Regulation of Great Lakes Water Pollution, 1945-1978." Business and Economic History 24:1 (Fall 1995), 147-154.

Kehoe, Terence. "'You Alone Have the Answer': Lake Erie and Federal Water Pollution Control Policy, 1960-1972." Journal of Policy History 8:4 (1996), 440469.

Melosi, Martin V. "Sanitary Services and Decision Making in Houston, 1876-1945." Journal of Urban History 20:3 (May 1994), 365-406.

Mallea, Amahia. "Downstreamers: Public Health and Relationships on the Missouri River.” Agricultural History 76:2 (Spring 2002), 393-404.

Nash, Linda. "The Changing Experience of Nature: Historical Encounters with a Northwest River." The Journal of American History 86:4 (Mar. 2000), 16001629. 
Olson, Sherry. "Downwind, Downstream, Downtown: The Environmental Legacy in Baltimore and Montreal." Environmental History 12:4 (2007), 845-866.

Paavola, Jouni. "Interstate Water Pollution Problems and Elusive Federal Water Pollution Policy in the United States, 1900-1948." Environment and History 12:4 (2006), 435-465.

Pisani, Donald J. "Fish Culture and the Dawn of Concern Over Water Pollution." Environmental Review 8:2 (1984), 117-131.

Pisani, Donald J. "The Polluted Truckee: A Study in Interstate Water Quality, 18701934." Nevada Historical Society Quarterly 20:3 (1977), 151-166.

Read, Jennifer. “'A Sort of Destiny': The Multi-Jurisdictional Response to Sewage Pollution in the Great Lakes, 1900-1930." Scientia Canadensis 22-23:51 (19981999), 103-129.

Robertson, Thomas. "'This is the American Earth': American Empire, the Cold War, and American Environmentalism." Diplomatic History 32:4 (Sept. 2008), 561584.

Rome, Adam W. "Coming to Terms with Pollution: The Language of Environmental Reform, 1865-1915.” Environmental History 1:3 (1996), 6-28.

Rome, Adam W. “'Give Earth a Chance': The Environmental Movement and the Sixties." The Journal of American History 89:2 (Sept. 2003), 525-554.

Rosen, Christine M. "Differing Perceptions of the Value of Pollution Abatement Across Time and Place: Balancing Doctrine in Pollution Nuisance Law, 18401906." Law and History Review 11:2 (Fall 1993), 303-381.

Sheail, John. "Town Wastes, Agricultural Sustainability, and Victorian Sewage." Urban History 23:2 (Aug. 1996), 189-210.

Searle, R. Newell. "Autos or Canoes? Wilderness Controversy in the Superior National Forest." Journal of Forest History 22:2 (1978), 68-77.

Shifrin, Neil S. "Pollution Management in the Twentieth Century." Journal of Environmental Engineering 131:5 (May 2005), 676-691.

Stradling, David, and Richard Stradling. "Perceptions of the Burning River: Deindustrialization and Cleveland's Cuyahoga River." Environmental History 13:3 (July 2008), 515-535. 
Tarr, Joel A. "From City to Farm: Urban Wastes and the American Farmer." Agricultural History 49:4 (Oct. 1975), 598-612.

Tarr, Joel A. "Industrial Waste Disposal in the United States as a Historical Problem." Ambix 49:1 (March 2002), 4-20.

Tarr, Joel A. "The Metabolism of the Industrial City: The Case of Pittsburgh." Journal of Urban History 28:5 (2002), 511-545.

Tierno, Mark J. "The Search for Pure Water in Pittsburgh: The Urban Response to Water Pollution, 1893-1914." The Western Pennsylvania Historical Magazine 60:1 (1977), 23-36.

Voyer, Richard A., Carol Pesch, Jonathan Garber, Jane Copeland, and Randy Comeleo. "New Bedford, Massachusetts: A Story of Urbanization and Ecological Connections." Environmental History 5:3 (2000), 352-376.

\section{Articles \& Book Chapters - Specific to Oregon, the Willamette River, Portland, etc.}

Benner, Patricia A., and James R. Sedell. "Upper Willamette River Landscape: A Historic Perspective," in Antonius Laenen and David A. Dunnette, eds., River Quality: Dynamics and Restoration. Boca Raton, Fla., Lewis Publishing, 1997, pp. 23-48.

Carter, Glenn D. "Pioneering Water Pollution Control in Oregon." Oregon Historical Quarterly 107:2 (Summer 2006), 254-272.

Everts, Curtis M. "Willamette Clean-up." Oregon State Game Commission Bulletin 8:7 (July 1953), 3-5.

Larson, Douglas W. "Reservoir Limnology in the Pacific Northwest: Willamette River Basin, OR." Lakeline, 21:4 (Winter 201/2002), 11-16.

Mahaffey, Juanita. "Pollution: The Worst Poacher." Oregon State Game Commission Bulletin 15:6 (June 1960), 3-4.

Mullane, Neil. "The Willamette River of Oregon: A River Restored?" in Antonius Laenen and David A. Dunnette, eds., River Quality: Dynamics and Restoration. Boca Raton, Fla., Lewis Publishing, 1997, pp. 65-76. 
Robbins, William G. "The Willamette Valley Project of Oregon: A Study in the Political Economy of Water Resource Development." Pacific Historical Review 47:4 (1978), 585-605.

Robbins, William G. "Willamette Eden: The Ambiguous Legacy." Oregon Historical Quarterly 99:2 (Summer 1998), 189-218.

Starbird, Ethel. “A River Restored: Oregon's Willamette." National Geographic 141:6 (June 1972), 816-834.

Stroud, Ellen. "Troubled Waters in Ecotopia: Environmental Racism in Portland, Oregon." Radical History Review 74 (1999), 65-95.

\section{Visual Media}

McCall, Thomas L., producer. Pollution in Paradise, television documentary. Portland, Oreg., KGW-TV, 1962.

Smith, William Joy, producer. Pollution in the Willamette, film. Portland, Oreg., William Joy Smith, 1940.

\section{Newspapers, Periodicals, \& Newsletters}

[Eugene, Oreg.] Commonwealth Review

League of Oregon Cities News Letter [Eugene]

The [Portland] Oregon Journal

Oregon State Game Commission Bulletin [Portland]

The [Portland] Oregon Voter

The [Portland] Oregonian

The Portland [Oreg.] Telegram

The [Portland, Oreg.] Spectator 


\section{APPENDiX A: POllution MANAGEMENT, 1900S-1970S - INTRODUCTION}

The pages that follow provide a brief comparative overview, in table form, of pollution management legislation and practices in the United States from 1900 to 1970 , correlated with significant events in national environmental history and the history of water pollution abatement efforts in Oregon. The tables were inspired by the works of Martin V. Melosi ${ }^{1}$ and Neil S. Shifrin. ${ }^{2}$ Specifically, Melosi provides the periodization of evolving public health and sanitary engineering practices, while Shifrin provides correlating periodization of federal initiatives and national pollution management practices.

Entries in the row titled "Selected Events in National Environmental History" are drawn from highlights of a general survey of twentieth century U.S. environmental history. Entries in the row titled "Selected Events in Oregon \& the Willamette Valley" are drawn from research articulated in this thesis.

\footnotetext{
${ }^{1}$ Martin V. Melosi, The Sanitary City: Urban Infrastructure in America from Colonial Times to the Present (Baltimore, Md., Johns Hopkins University Press, 2000), 12-14. Footnote \#1 in the tables that follow correlate to this citation.

${ }^{2}$ Neil S. Shifrin, "Pollution Management in the Twentieth Century," Journal of Environmental Engineering 131:5 (May 2005), 677, 681. Footnote \#2 in the tables that follow correlate to this citation.
} 


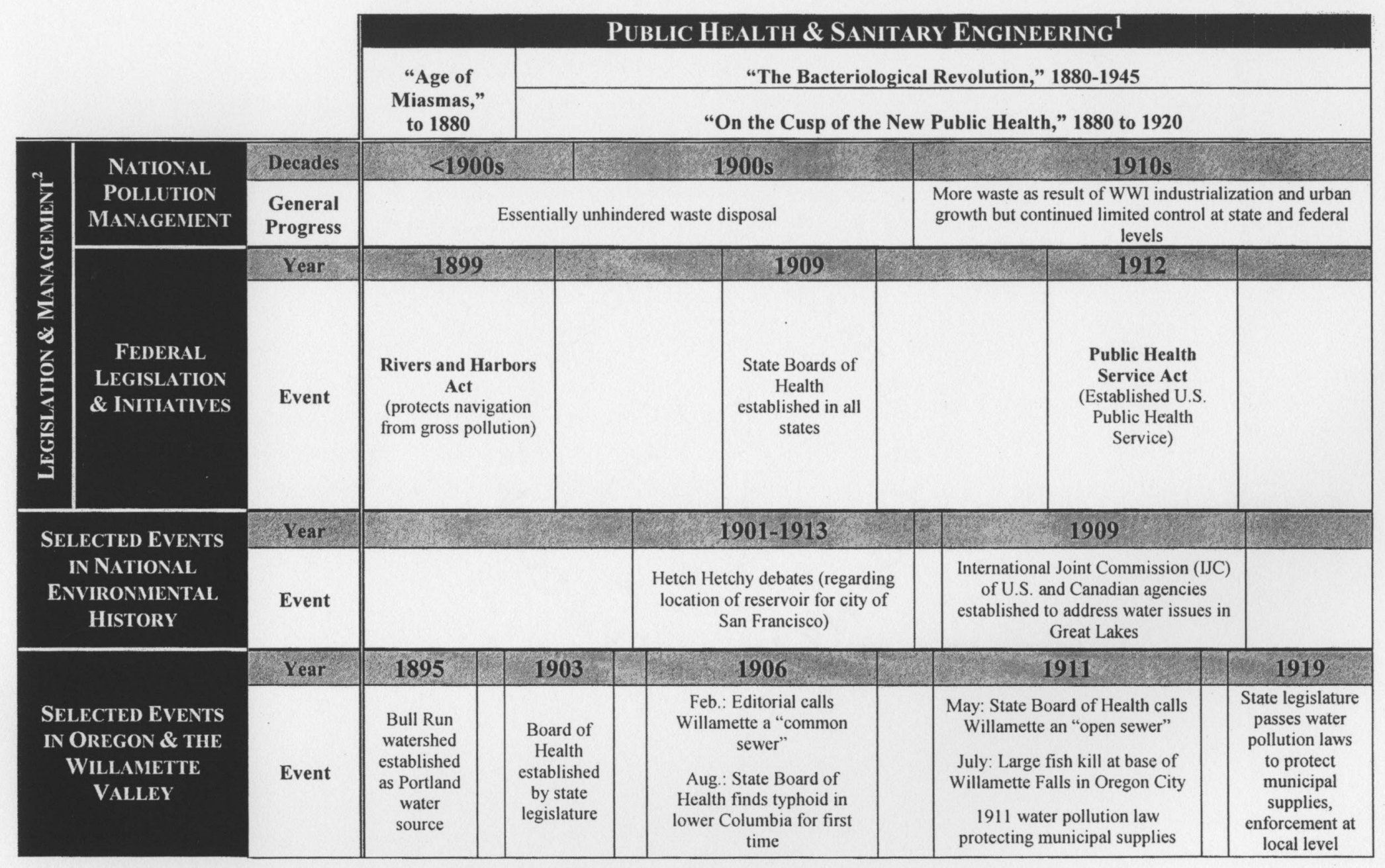




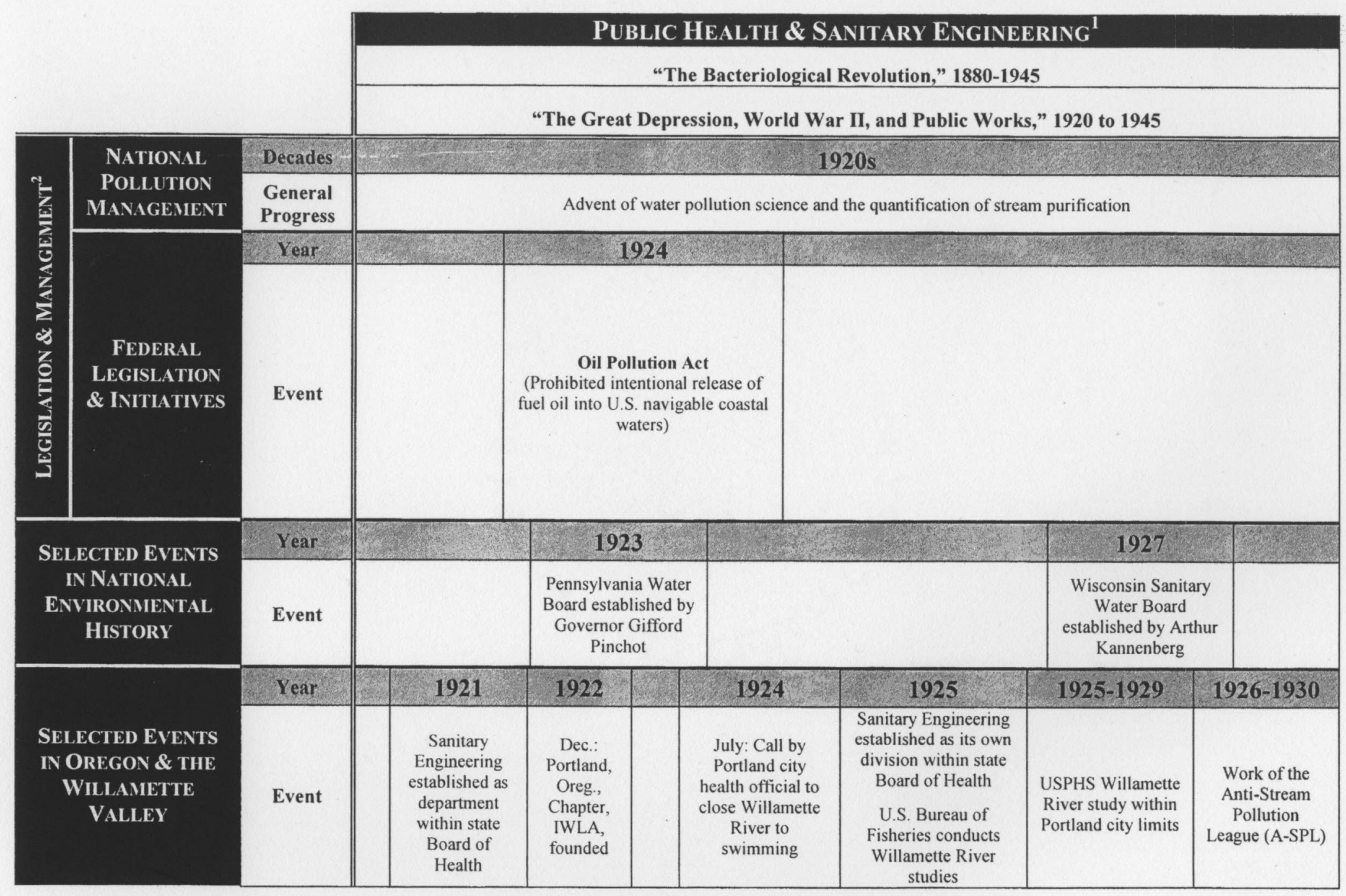




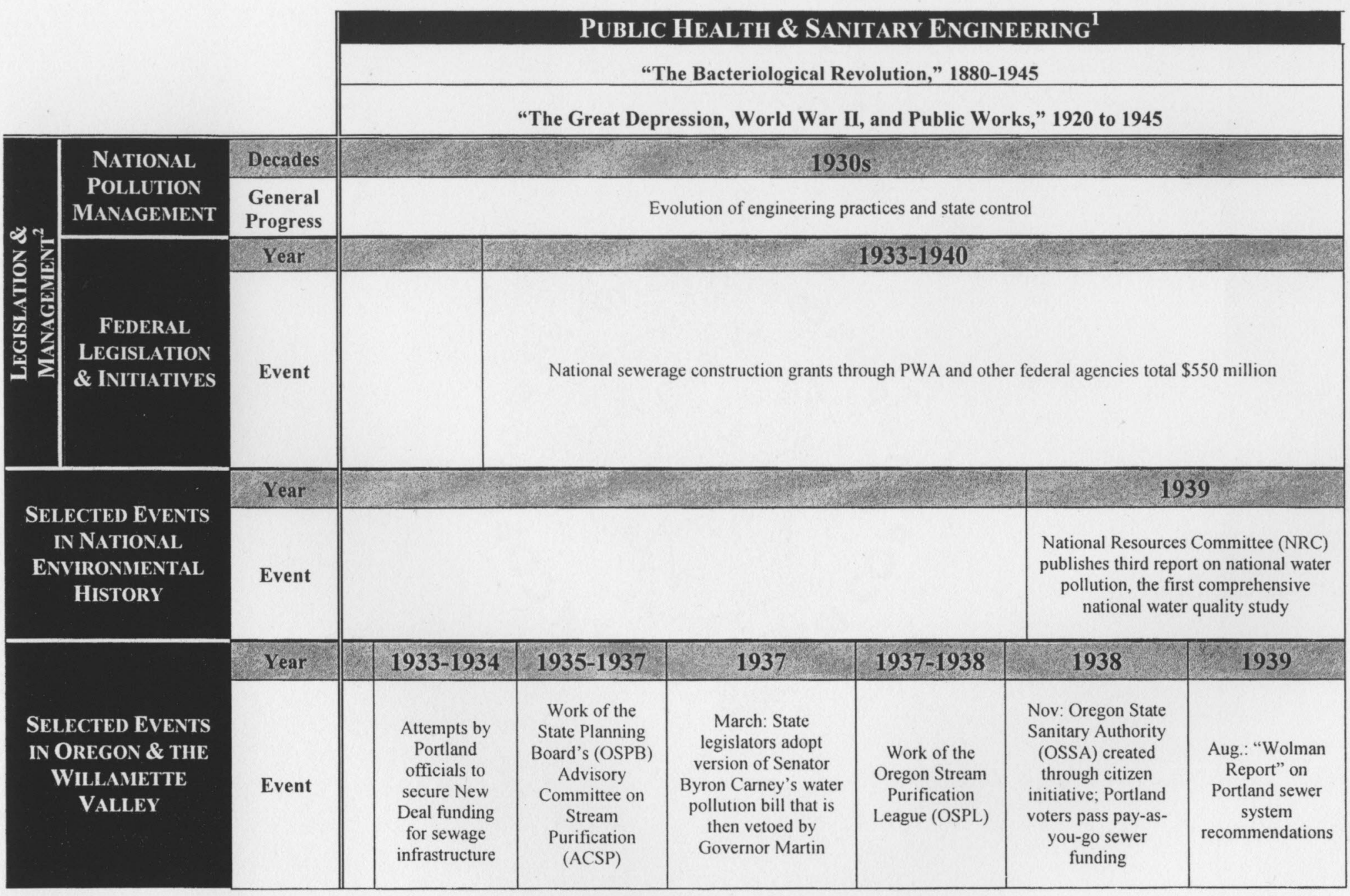

$\vec{\omega}$ 


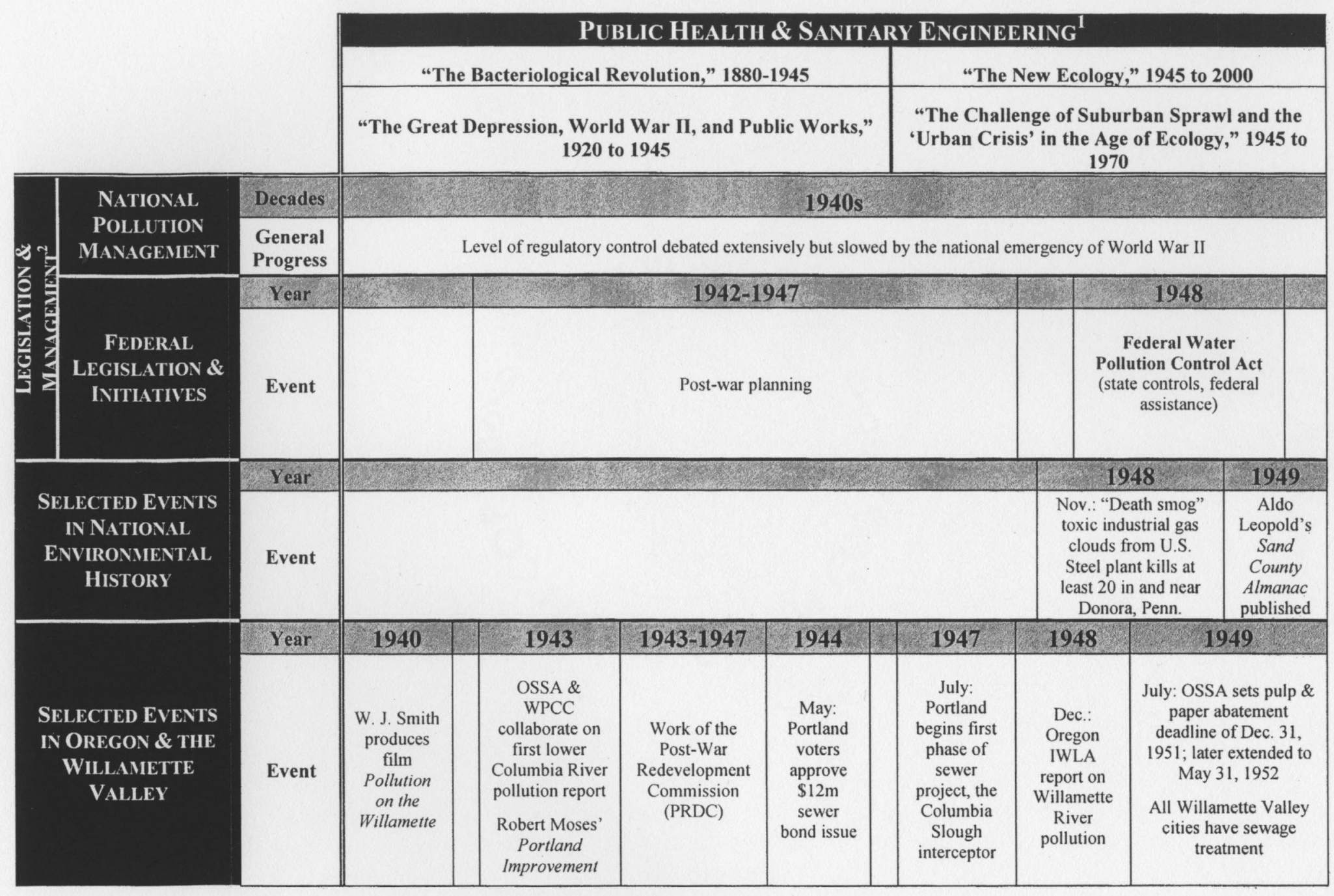




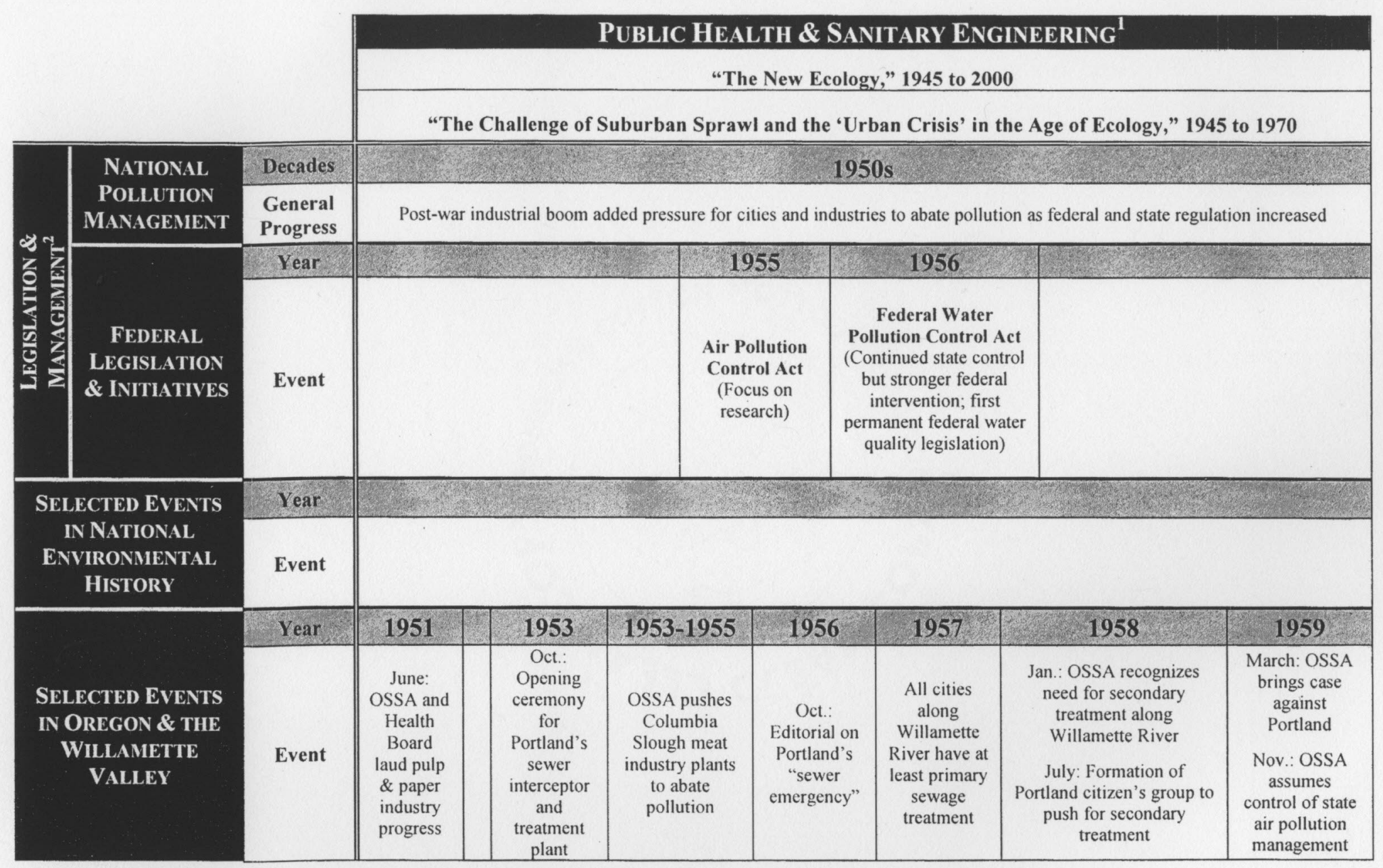




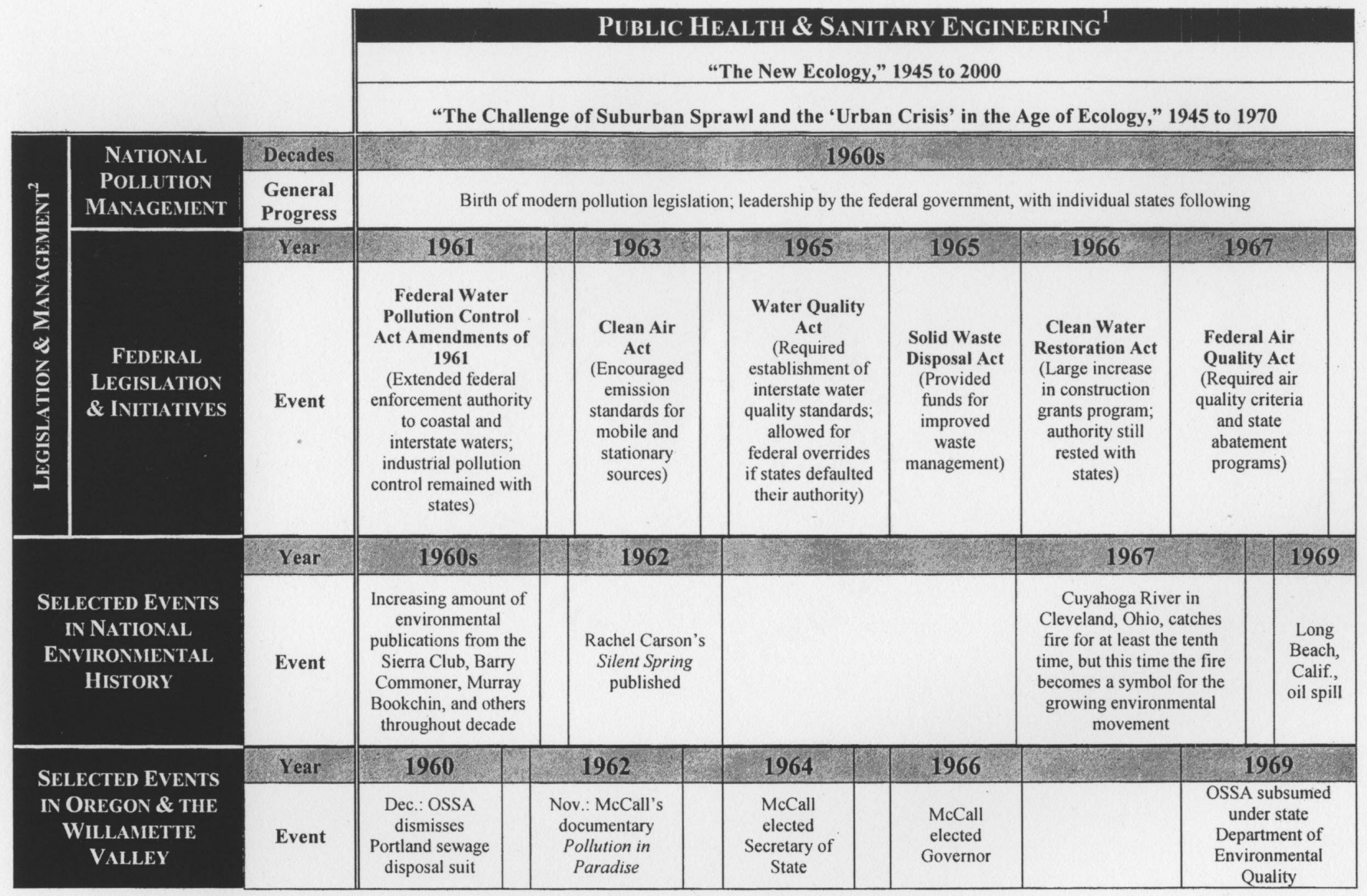




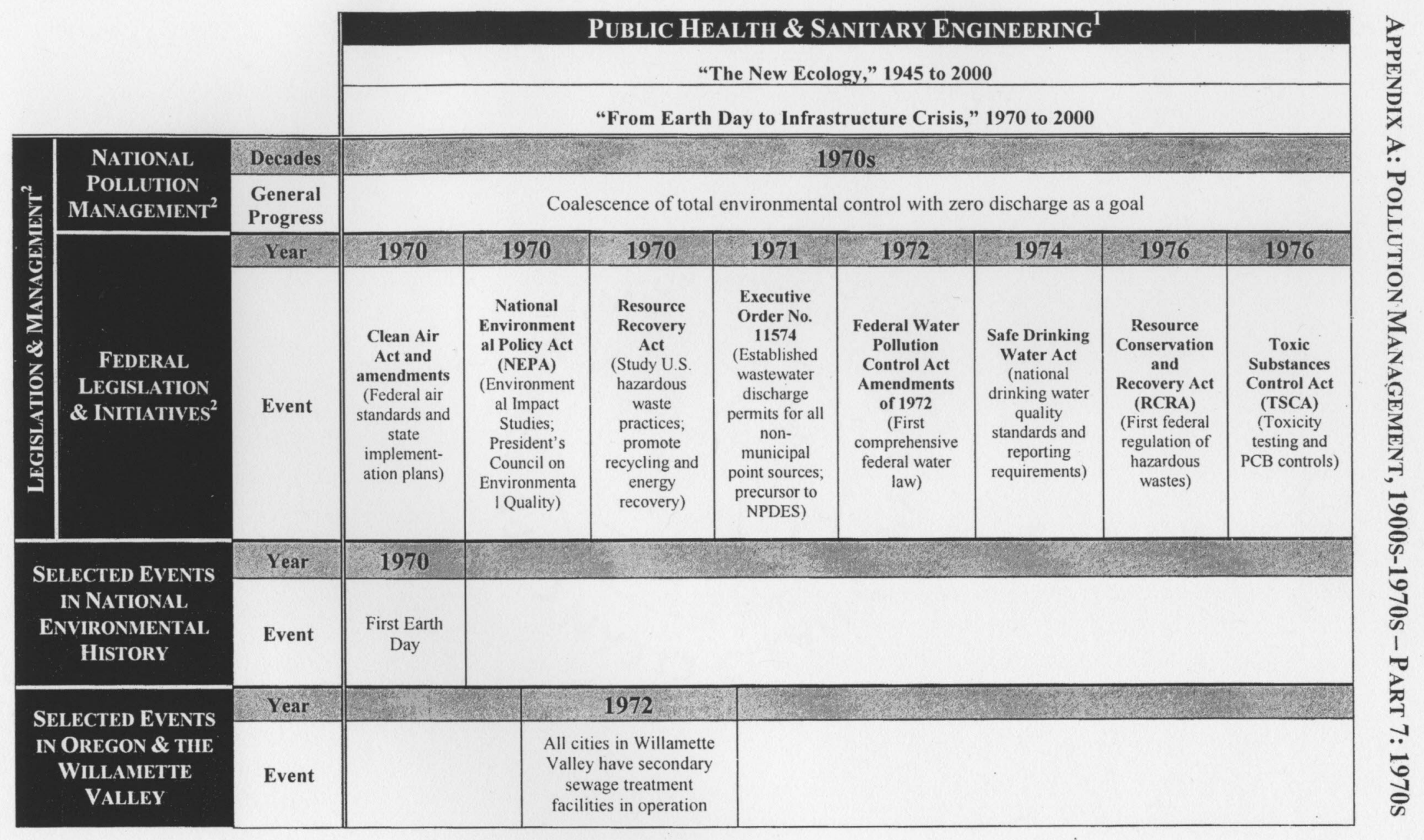

초 


\section{APPENDIX B: The OREgon DIVISION, IZAAK WALTON LEAGUE OF AMERICA}

Izaak Walton League of America (IWLA) members William L. Finley and Edgar F. Averill were among the earliest water pollution abatement advocates in Oregon. In the mid-1930s, David B. Charlton joined the organization and contributed to the efforts of Finley, Averill, and other Oregon Division, IWLA, members to clean up the Willamette.

In other states as well, IWLA members were leaders in water quality and pollution abatement issues beginning in the early 1920s. In Oregon and across the nation, "Waltonians," as they were known, greatly expanded the previous conservation efforts of sportsmen's groups that had been concerned with the detrimental impacts of industrialization, urbanization, and waste disposal practices on fish and game populations since the mid-nineteenth century. IWLA members joined public health officials, sanitary engineers, and regional planners-many of whom were also concurrently members of the IWLA - to serve as the most important groups advocating for clean streams prior to the passage of enhanced federal regulations in the late 1960 s and early 1970 s.

Historiography of the Izaak Walton League of America

Almost without exception, scholars writing about water pollution issues of the first seventy years of twentieth-century must (and generally do) mention the 
contributions of the Izaak Walton League at the state and/or national level. However, to date no historian has written a comprehensive study of the IWLA. Reviewing the available literature, one can piece together some context for national and state league actions, policies, and advocacy on the issue of water quality and water resources conservation generally.

Works by Nicholas Casner and Philip V. Scarpino show how the local and state league efforts expanded to provide examples and precedents for other states and the national organization. Casner highlights the involvement of Kenneth Reid in IWLA pollution abatement efforts in Pennsylvania beginning in the 1920s; Reid would become national director of the league in 1936 and expand the group's involvement in water quality issues until his death in 1956. In a chapter dedicated to the IWLA, Scarpino provides a brief biography of founder Will Dilg and examines the first years of the group's magazine, Outdoor America, to articulate the essence of the group's message and methods. Following this, Scarpino writes about specific Waltonian actions in Minneapolis and St. Paul, Minnesota, in reaction to pollution, dam construction, and channelization along the Upper Mississippi in the 1920s and 1930s. ${ }^{1}$

A number of historical studies provide some details of IWLA efforts to shift federal water quality and general conservation regulations from the 1920 s into the early 1970s. In addition to Casner's and Scarpino's research, Terence Kehoe, Paul Charles Milazzo, and Jouni Paavola identify specific instances when IWLA members initiated campaigns, formed action committees, filed injunctions, and provided 
testimony at legislative hearings with the express intent of shaping national water management policy. R. Newell Searle identifies the critical role league members played in establishing a roadless policy for the Boundary Waters Canoe Area of the Superior National Forest of Minnesota in the 1920s. Searle's study, while not focused on water quality issues, contributes to other researching showing the influence of the IWLA in lobbying federal agencies and helping to steer national conservation policies. $^{2}$

Thomas Howard Hayden wrote a Master's Thesis about the activities of the Minnesota Division of the IWLA from 1922 to 1972 published as a book by the Minnesota Division in 2001. Hayden includes chapters on Upper Mississippi river channelization and water quality, the establishment of the Boundary Waters Canoe Area, and the creation of the Twin Cities Sanitary District in the early 1930s to address the problem of municipal wastes. ${ }^{3}$

The Izaak Walton League of America

Sportsmen's groups had been a feature of American society since at least the mid-nineteenth century, but by the first decades of the twentieth century membership in organized hunting and fishing clubs increased markedly. The number of hunting and fishing licensees doubled from six to twelve million between 1910 and 1920, for example. ${ }^{4}$ Fifty-four men meeting at the Chicago Athletic Club in January 1922 formed the Izaak Walton League of America. Their goal was to bring together the 
membership and interests of angling and hunting groups within a national framework.

League founders named their organization for a seventeenth-century English writer and angler. Within two years of its founding, the organization numbered more than 100,000 members nationally. In 1928 the organization had 175,000 members in three thousand chapters in forty states. For comparison, three older conservation groups - the Audubon Society, Sierra Club, and American Game Protective Association—had no more than 21,000 members combined in $1924 .{ }^{5}$ A conception of nature that combined practical conservation goals with spiritual reverence and mourning for the loss of outdoor recreational opportunities motivated prominent IWLA leaders, including founder and first president Will Dilg. League leaders translated these motivations into consistent and prolonged efforts to lobby policy makers, sustain broad-based membership drives, and educate the public, particularly youth.

IWLA national leadership established the framework to be followed by state divisions and local chapters. As articulated in the mid-1940s, league policy was to work through federal, state, and local government agencies to achieve their conservation objectives. League efforts would support government actions when they reflected IWLA goals, but members were also prepared to "fight these agencies just as hard as we have supported them, should the go haywire or come under adverse political domination."

In 1926, after financial irregularities forced Dilg to resign as the organization's president, the incoming IWLA leadership committed the group to addressing water 
pollution as their highest priority. ${ }^{7}$ IWLA water pollution policy expressed in 1946 included assertions that the issue was a national problem requiring a uniform, nationwide approach, and that research and development of industrial waste abatement solutions were legitimate business expenses industry should properly bear. ${ }^{8}$

Growing interest in outdoor recreation offered through sportsmen's organizations such as the IWLA, the Boone and Crockett Club, and a host of local and regional angling and hunting groups, reflected a changing relationship many Americans experienced toward their environment. These changes were in large measure a result of increasing affluence that fostered a growing middle class. Other contributing factors were the ability of more Americans to take advantage of shorter work weeks and the automobile's mobility to escape into the countryside. ${ }^{9}$

This newly-evolving relationship of Americans to their landscape was predicated to a significant degree upon more democratic access to outdoor recreational opportunities as well as a changing relationship to the landscape from one of sustenance through production and extraction to the experience of the environment in its "natural" state-that is, the "amenity value" of nature. A critical aspect of the IWLA and its constituent city and regional chapters and state divisions was the goal of conservation of these landscapes for recreation and contemplation. ${ }^{10}$ As historian Philip Scarpino notes, the IWLA "validated and gave focus to attitudes that had already begun to take shape"-attitudes that included advocating for water pollution abatement regulations and practices. ${ }^{11}$

As these groups grew they reflected a more diverse cross-section of the 
population. Although membership in sportsmen's organizations was still largely male, women were not absent from the IWLA or other such groups. For instance, in 1933 Ernest L. Crockatt, Assistant Supervisor of the Oregon State Game Commission, wrote to John B. Ebinger, President of the Oregon Division, IWLA, describing support for the work of state agencies on pollution abatement. Crockatt observed that We have received endorsement of this program from the Federated Women's Clubs of Oregon, representing more than 50,000 members; from the Women's Greater Oregon Association, representing 23,000 members in 300 communities of the state; and from the state president of the Women's Business and Professional Club. In addition, the Ladies Rod and Gun Club of Baker County and many other interested women have endorsed this program ... ${ }^{12}$

In addition to women's involvement as individuals in league chapters throughout the nation, by the early 1950 s there were all-women IWLA chapters in fourteen states (although there were no such exclusive chapters in Oregon). ${ }^{13}$ At the national and state levels the IWLA represented growing interest in conservation and water quality issues among an expanding number of Americans.

Portland Chapter and Oregon Division, Izaak Walton League of America

Local civic leaders, conservationists, and other men formed the Portland Chapter of the Izaak Walton League on December 15, 1922. The organization's first elected officers included President Noyes E. Tyrrell (who had been a charter member of the Multnomah Anglers' Club, organized circa 1903), Vice President John Gill (a state senator), and Secretary A. Benz. The executive committee included naturalist William L. Finley, Mazamas mountaineering club president John A. Lee, and 
conservationist, journalist, and newspaper editor Marshall Dana. This organizational meeting came just a week after the Chicago Chapter of the IWLA honored Finley for his contributions to the causes of conservation and preservation. ${ }^{14}$

The Oregon Division, IWLA, continued to grow its membership and increase its involvement in issues of water pollution in Oregon throughout the 1920s and 1930s. By 1943 there were chapters throughout the state-including Tillamook, Marshfield [Coos Bay], Silverton, Klamath Falls, and Astoria-and the membership of the Portland Chapter itself had grown to $117 .{ }^{15}$ The Portland Chapter of the IWLA had grown to "an all-time high" of 419 in October 1959, and the state division membership numbered 1,761 that year. ${ }^{16}$ However, in the decades after World War II membership growth rates in Oregon and in most other states peaked and in many cases began to decline, even as the state and national organizations became increasingly more active and effective in their water pollution abatement efforts. ${ }^{17}$

Membership in the Portland Chapter, IWLA, represented a broad spectrum of professions. In 1959, for example, the membership list included officials from municipal, state, and federal agencies, professionals in the fields of medicine, law, finance, sales, education, food service, publishing, brewing, insurance, metal fabrication, manufacturing, print and broadcast media, and — perhaps surprisinglyrepresentatives of the wood products and pulp and paper industries. ${ }^{18}$ To illustrate the ways in which IWLA members organized their activities, committees of the Portland Chapter in 1943 included City Hall Representatives, Conservation, Legislative, Membership, Programs, Publicity and Public Relations. ${ }^{19}$ Reflecting increased 
membership and areas of concern, by 1949 the list of Portland Chapter committees had expanded to include Big Game, Boy Scouts, Clackamas Property [IWLA-owned recreational property on the Clackamas River], the Columbia River Basin Project, Conservation Education, Dams and Water Diversions, Fisheries, Forestry, Legislative, Migratory Waterfowl, Soil Conservation, Stream Purification, and the Willamette River Project. ${ }^{20}$

As the range of these committees suggests, the interests of league members in Oregon included water pollution as one important element of an overall natural resources conservation approach. While most members welcomed the construction of irrigation and hydroelectric dams in the region, the Oregon Division was also at the forefront of opposition to certain water impoundment proposals on the Columbia, Willamette, McKenzie, Deschutes, Rogue, and other state rivers, particularly after World War II. For example, the Oregon IWLA collaborated with Richard Neuberger and other groups to oppose the Beaver Marsh dam project on the upper McKenzie and the Pelton Dam project on the Deschutes, both in the mid-1950s. The Oregon IWLA also opposed some dams proposed for the Columbia and tributaries of the Willamette River. ${ }^{21}$ Such advocacy reflects the general Waltonian focus on identifying achievable goals to sustain a balance between stream development and recreational use.

Over the course of his long involvement in state and national water quality issues, David B. Charlton recognized the impossibility of achieving a "pristine" Willamette River. Charlton was one of William Finley's recruits to the Portland Chapter in the early 1930s. He wrote of his decision to become involved in the IWLA 
that

My becoming a Waltonian in 1934 resulted from my visit to the Portland chapter meeting when there was much uncertainty on how to get Portland to do something on its sewage disposal problem. Perhaps my greatest inspiration and awareness of wildlife and conservation problems come from contact with Bill and Irene Finley. ${ }^{22}$

In addition to Charlton's increasingly prominent role specifically on the issue of water pollution, he was also elected to serve as the Oregon Division, IWLA, President in $1949 .{ }^{23}$ In 1961, Charlton received the American Motors Conservation Award in recognition of his efforts in the field of water pollution abatement. ${ }^{24}$

In all significant ways, Charlton's involvement with the Portland Chapter, Oregon Division, and national IWLA reflects the approach of the organization itself. Charlton was motivated both as a professional water quality chemist and as a citizen concerned with increasingly degraded water. He was also fully aware of what was achievable given the political, social, economic, and ideological realities of the twentieth-century United States. Writing in November 1959, Charlton observed that I am not one that believes that the Willamette River will ever be entirely 'cleaned up.' A certain amount of industrials wastes, effluents from sewage plants etc. will make the river unfit for swimming but I am at least hopeful that a reasonable oxygen content will be maintained in the future even during the low water season. ${ }^{25}$

Such a perspective was dominant before the "zero discharge" goal was codified in federal legislation of the late 1960 s and early $1970 \mathrm{~s}^{26}$ With this perspective, Charlton shared the opinion of most public health officials, sanitary engineers, and regional planners - and reflected the approach of the IWLA.

\footnotetext{
${ }^{1}$ Nicholas Casner, "Angler Activist: Kenneth Reid, the Izaak Walton League, and the Crusade for Federal Water Pollution Control," Pennsylvania History 66:4 (1999), 535-553; Philip V. Scarpino, Great River: An Environmental History of the Upper Mississippi, 1890-1950 (Columbia, Mo., University of Missouri Press, 1985), particularly chapters 4 and 5, pp. 114-186.
} 
${ }^{2}$ Terence Kehoe, Cleaning Up the Great Lakes: From Cooperation to Confrontation (DeKalb, Ill., Northern Illinois University Press, 1997), particularly pp. 23, 53, 113, and 117; Paul Charles Milazzo, Unlikely Environmentalists: Congress and Clean Water, 1945-1972 (Lawrence, Kans., University Press of Kansas, 2006), particularly pp. 147-148, 238; Jouni Paavola, "Interstate Water Pollution Problems and Elusive Federal Water Pollution Policy in the United States, 1900-1948, Environment and History 12:4 (2006), 448-452; R. Newell Searle, "Autos or Canoes? Wilderness Controversy in the Superior National Forest," Journal of Forest History 22:2 (1978), 68-77.

${ }^{3}$ Thomas Howard Hayden (Paul E. Toren, ed.), Citizen Leadership in Conservation: The Minnesota Izaak Walton League, 1922-1973 (St. Paul, Minn., Izaak Walton League Minnesota Division, 2001).

${ }^{4}$ Nicholas Casner, "Angler Activist," 536-537. For more on the role of sportsmen's groups in nineteenth century conservation efforts, see John F. Reiger, American Sportsmen and the Origins of Conservation ( $3^{\text {rd }}$ edition) (Corvallis, Oreg., Oregon State University Press, 2001).

${ }^{5}$ Scarpino, Great River, 117-119.

${ }^{6}$ Izaak Walton League of America, "Policies of the Izaak Walton League: A Guide for Waltonians on Matters of Policy," June, 1946, p. 6, folder Oregon Division - Izaak Walton League 29th Annual Convention December 1951 Portland Oregon, box 8, David B. Charlton Papers (MSS 1900), Oregon Historical Society Research Library, Portland, Oreg. [hereafter Charlton Papers].

${ }^{7}$ Scarpino, Great River, 120-121, 150.

${ }^{8}$ Izaak Walton League of America, "Policies of the Izaak Walton League," p. 14.

${ }^{9}$ Nicholas Casner, "Angler Activist," 536-537; see also Reiger, American Sportsmen, and Lawrence M. Lipin, Workers and the Wild: Conservation, Consumerism, and Labor in Oregon, 1910-30 (Urbana, Ill., University of Illinois Press, 2007).

${ }^{10}$ Reiger, American Sportsmen; quote is from p. 3, and Chapter 3 (pp. 67-104) is specifically devoted to the role of sports fishermen in the development of the conservationist approach. For an analysis of the increased involvement among the working class in sportsmen's groups, see Lipin, Workers and the Wild. For more on the shift from production to consumption values of nature, see Samuel P. Hays, Explorations in Environmental History: Essays (Pittsburgh, Pa., University of Pittsburgh Press, 1998), particularly 395-396, 421-422, Gregory Summers, Consuming Nature: Environmentalism in the Fox River Valley, 1850-1950 (Lawrence, Kans., University Press of Kansas, 2006), particularly 4-8, and Scarpino, Great River, 128.

"Scarpino, Great River, 117.

${ }^{12}$ For more on women's involvement in the IWLA, see the five-page outline of ways for IWLA members and other pollution abatement advocates to collaborate more effectively with state women's groups, titled "Program for Women's Work," undated, attached to Ernest L. Crockatt, Assistant Supervisor, Oregon State Game Commission, to John B. Ebinger, President, Oregon State Council, IWLA, May 13, 1933, both in folder National Izaak Walton League 1932-1934, box 8, Charlton Papers. For the efforts of Will Dilg and other national IWLA leaders to involve women in IWLA activities, see Scarpino, Great River, 137.

${ }^{13}$ See "Oregon Division, Izaak Walton League of America, Inc., Monthly Bulletin, May 1952," p. 3, in folder Oregon Izaak Walton League 1951-1953, box 8, Charlton Papers.

14 "Local Anglers Elect," Morning Oregonian, Dec. 16, 1922, p. 16; "Izaak Walton League Chapter is Formed Here," Oregon Sunday Journal, Dec. 17, 1922, sec. 2, p. 2.

${ }^{15}$ For state chapters, see H. Abbott Lawrence to Lew Wallace, State Senator, March 8, 1941, folder Portland Chapter-Izaak Walton League 1941 Cougar Picnic, box 8, Charlton Papers; for membership number, see "Portland Chapter - Izaak Walton League - Members - January, 1943," folder Portland Chapter-Izaak Walton League 1943, box 8, Charlton Papers.

${ }^{16}$ For the October 1959 Portland Chapter membership numbers, see "Portland Waltonian," Oct. 1959, p. 1., and for the 1959 Oregon Division membership numbers, see "Portland Waltonian, Sept. 1960, p. 2, both in folder Portland Chapter-Izaak Walton League 1959, box 8, Charlton Papers. 
${ }^{17}$ For the relative decrease in national IWLA membership after World War II from its peak in the 1930s and early 1940s, see Scarpino, Great River, 192-193.

18 "1959 Roster Portland Chapter Izaak Walton League of America," folder Izaak Walton League 19221958, series I: Personal Records, subgroup 1: Personal/Family Records, EE Wilson Papers, Oregon State University Archives, Corvallis, Oreg.

19 "Portland Chapter - Izaak Walton League - Members - January, 1943."

${ }^{20}$ Fred H. Kennedy, Chairman, Special Committee, to Committee Chairmen, Portland Chapter, IWLA, June 22, 1949, folder Portland Chapter-Izaak Walton League 1948-1949, box 8, Charlton Papers.

${ }^{21}$ For this opposition, see William G. Robbins, Landscapes of Conflict: The Oregon Story, 1940-2000 (Seattle, Wash., University of Washington Press, 2004), particularly 53-55, 64, 234-236, and 241-245.

${ }^{22}$ Charlton to "Dear Al," April 9, 1975, folder Correspondence re: Water Pollution 1930-1950, box 18, Charlton Papers.

23 "Charlton Heads Walton League," Oregonian, Sept. 21, 1949, sec. 3, p. 2.

${ }^{24}$ Charlton to Mr. Gus Hann, Chairman, IWLA Nomination Committee, March 12, 1962, folder Izaak Walton League: 1962 Convention Resolutions, box 8, Charlton Papers.

${ }^{25}$ Charlton to Harold Wendel [Chairman, Oregon State Sanitary Authority], Nov. 23, 1959, p. 1, folder Correspondence re: Pollution 1949-1950, box 18, Charlton Papers.

${ }^{26}$ For development of this approach to water quality management, see Neil S. Shifrin, "Pollution Management in the Twentieth Century," Journal of Environmental Engineering 131:5 (May 2005), 676-691, Paavola, "Interstate Water Pollution Problems," and Milazzo, Unlikely Environmentalists. 


\section{Appendix C: AN ANALYSis of Pollution in PaRAdise}

Pollution in Paradise was ground-breaking as a public relations tool and an effective, concise statement of environmental degradation. As historians William G. Robbins and Brent Walth identify, the positive response to McCall's documentary helped propel him to Oregon's governorship in 1966. McCall's documentary is also representative of a new era in state environmental politics.

Evaluating the story of Willamette River water pollution abatement, one is struck by a few things. First, McCall was not timid or equivocal on the issue of water pollution as his biographer Brent Walth observes, but neither was William L. Finley or David B. Charlton. ${ }^{1}$ Second, McCall entwined morality with environmental and economic health, but so did a number of pollution abatement advocates from at least the $1920 \mathrm{~s}^{2}$ Third, there were a variety of politicians intimately involved in key aspects of the movement, such as Senator Byron Carney, who had prepared at least two bills for the state legislature before he became a member of the Oregon Stream Purification League (OSPL) and led efforts to craft the successful 1938 citizen initiative, and both State Treasurer Rufus C. Holman and Senator Frank Franciscovich were founding members of the Oregon Stream Purification League. Fourth, McCall himself had been speaking on the issue of conservation and had even produced other highly-regarded documentaries before Pollution in Paradise. ${ }^{3}$ Finally, William Joy Smith produced a color film in 1940 showcasing the extreme pollution of the Willamette from Springfield to Portland's harbor. Why did the abatement movement not attain the 
achievements it did until after McCall's 1962 documentary?

One element that makes the repercussions of McCall's documentary noteworthy both in his political career and in state environmental policy is that it marked the first time someone with his renown, public persona, and political aspirations had taken up the water pollution issue. Prior to this, the issue was largely under the purview of specialists or members of organizations focused on the topic.

McCall's documentary also had a strong impact after 1962 because of achievements and frustrations over the course of the previous thirty-five-plus years. Progress on Willamette River water pollution was incremental, hard-fought, and often temporary, but the work of Finley, Charlton, the Oregon Izaak Walton League, and others both facilitated and challenged the work of the Oregon State Sanitary Authority. It was the persistence of these individuals and groups from the 1920s through the early 1960s that established the parameters of what was possible and provided examples of what was not effective.

A third important reason for the impact of McCall's documentary, and subsequent achievements in environmental policy during his time as governor, was that the appearance of Pollution in Paradise was "serendipitous," as Robbins observes. Pollution abatement advocates in Oregon and nationally were able to build upon momentum from a wide array of areas such as increased ecological understanding of environmental concerns and application of this understanding in federal legislation. ${ }^{4}$ Also, American society in the late 1950s and early 1960s was in the midst of a shift in perceptions of nature spurred by increased affluence and leisure 
time. ${ }^{5}$ McCall's documentary aired at a time when science was becoming better able to quantify and frame environmental impacts while increasingly more Americans had the time and money available to conceive of nature in other than extractive terms.

Finally, as important as all the reasons outlined above, the environment itself, as a "physical agent," was reacting to decades of minimally-regulated waste disposal practices. By the late 1950s, the environment was undeniably curtailing the accustomed activities and constraining future options of a growing number of people across all race, class, gender, political, and geographic lines. ${ }^{6}$ More and more Americans were questioning destructive suburban development patterns, unregulated use of pesticides, continued dam construction, and many other activities that had not been systematically scrutinized to that point. ${ }^{7}$

Rachel Carson's book Silent Spring has much in common with the documentary Pollution in Paradise, and it is valuable to compare these two groundbreaking environmental exposés. Silent Spring was published on September 27, 1962, just a few weeks before McCall's documentary. ${ }^{8}$ Historian Priscilla Coit Murphy finds that most environmentalists and environmental historians characterize the modern environmental movement as composed of "Before Carson" and "After Carson" periods. ${ }^{9}$ Similarly, many analyses of Willamette River water pollution abatement efforts point to a "Before McCall" and "After McCall" delineation, with nothing much happening Before McCall. The truth, as we have found, is more complex.

The medium of the printed word was critical to the impact of Rachel Carson's 
research, just as the medium of the television documentary was critical in the reception of McCall's message. Carson used her book to cite exhaustively the scientific evidence to make her case about the harm caused by DDT and other chemicals, and McCall built upon his years in radio and television to create strong narrative backed by graphic color images of polluted air and water. Additionally, both Carson and McCall brought significant experience to their projects; both were recognized as skilled in their respective mediums; both were pursuing topics that were far from unknown but for which a "critical mass" of the general public was not sufficiently concerned; and both were given significant leeway and institutional insulation in pursuing their work. ${ }^{10}$

Murphy describes the early 1960s as a time during which both the general public and news media were becoming increasingly aware of and concerned with environmental topics. This period was the "heyday of the television documentary," according to Murphy. A prime example of the positive power of the television documentary was Edward R. Morrow's acclaimed exposé of the agricultural industry's mistreatment of migrant workers, Harvest of Shame, aired by CBS Reports in 1960. In both broadcast and print form, stories highlighting water pollution and other examples of environmental degradation increased throughout the $1950 \mathrm{~s}$ and early $1960 \mathrm{~s} .{ }^{11}$

There is an important element that makes works like Silent Spring and Pollution in Paradise different from works produced in the early and mid 1960s on environmental issues by the Sierra Club, Murray Bookchin, Barry Commoner, and others. Carson's and McCall's works were meant for a broader audience, not 
necessarily those with sufficient time and money to travel to far-off wilderness areas

or with the background and time to digest relatively complex intellectual arguments.

Both Carson and McCall were able to frame complex ecological issues in ways the

general public understood. Such an understanding was facilitated in part by specific

episodes of undeniable environmental deterioration—such as the September 1949

crawfish die-off in the lower Willamette-that Carson, McCall, and others placed

within a broader narrative. ${ }^{12}$

\footnotetext{
' See Brent Walth, Fire at Eden's Gate: Tom McCall \& the Oregon Story (Portland, Oreg., Oregon Historical Society Press, 1994), 77-112 and 149-159, and William G. Robbins, Landscapes of Conflict: The Oregon Story, 1940-2000 (Seattle, Wash., University of Washington Press, 2004), 266.

${ }^{2}$ Robbins, Landscapes of Conflict, 266.

${ }^{3}$ For example, McCall's documentary Crisis in the Klamath Basin of 1958.

${ }^{4}$ See Peter J. Bowler, The Norton History of the Environmental Sciences (New York, W. W. Norton \& Company, 1993), and Paul Charles Milazzo, Unlikely Environmentalists: Congress and Clean Water, 1945-1972 (Lawrence, Kans., University Press of Kansas, 2006).

${ }^{5}$ Ben A Minteer, The Landscape of Reform: Civic Pragmatism and Environmental Thought in America (Cambridge, Mass., The MIT Press, 2006); Samuel P. Hays, Explorations in Environmental History: Essays (Pittsburgh, Pa., University of Pittsburgh Press, 1998); and Richard W. Judd and Christopher S. Beach, Natural States: The Environmental Imagination in Maine, Oregon, and the Nation (Washington, D.C., Resources for the Future, 2003).

${ }^{6}$ See Matthew Klingle, Emerald City: An Environmental History of Seattle (New Haven, Conn., Yale University Press, 2007), 9. Rachel Carson herself asserted that the 1959 "cranberry scare," in combination with radiological contamination of milk and fear of birth defects caused by the drug thalidomide, contributed to the strong popular reception of her serialized articles and book. See Priscilla Coit Murphy, What a Book Can Do: The Publication and Reception of Silent Spring, (Amherst, Mass., University of Massachusetts Press, 2005), 37.

${ }^{7}$ See, for example, Murphy, What a Book Can Do; Adam W. Rome, The Bulldozer in the Countryside: Suburban Sprawl and the Rise of American Environmentalism (Cambridge, U.K., Cambridge University Press, 2001); and Gregory Summers, Consuming Nature: Environmentalism in the Fox River Valley, 1850-1950 (Lawrence, Kans., University Press of Kansas, 2006).

${ }^{8}$ Murphy, What a Book Can Do, 3.

${ }^{9}$ Murphy, What a Book Can Do, 202.

${ }^{10}$ For these aspects of Rachel Carson's Silent Spring, see Murphy, What a Book Can Do.

${ }^{11}$ Murphy, What a Book Can Do, 11-14. Terence Kehoe also finds television and print media reports in the early 1960s critical in bringing about a shift in Americans' approach to the environment; see Kehoe, Cleaning Up the Great Lakes: From Cooperation to Confrontation (DeKalb, Ill., Northern Illinois University Press, 1997), 8.
} 
${ }^{12}$ Murphy, What a Book Can Do, 199-221. 